1

2

3

\title{
Oxygen in the Iberian margin: a modelling study
}

\author{
Rosa Reboreda ${ }^{\mathrm{a}, *}$, Carmen G. Castro ${ }^{\mathrm{b}}$, Xosé A. Álvarez-Salgado ${ }^{\mathrm{b}}$, Rita \\ Nolasco $^{a}$, Nuno G. F. Cordeiro ${ }^{\mathrm{a}}$, Henrique Queiroga ${ }^{\mathrm{c}}$, Jesus Dubert ${ }^{\mathrm{a}}$ \\ ${ }^{a}$ CESAM and Departamento de Física, Universidade de Aveiro, Campus de Santiago, \\ 3810-194, Aveiro, Portugal \\ ${ }^{b}$ IIM-CSIC, Instituto de Investigacións Mariñas, Eduardo Cabello 6, 36208 Vigo, Spain \\ ${ }^{c}$ CESAM and Departamento de Biologia, Universidade de Aveiro, Campus de Santiago, \\ 3810-194, Aveiro, Portugal
}

\begin{abstract}
Highly productive eastern boundary coastal upwelling areas provide interesting environments to study the physical-biological interactions that govern dissolved oxygen $\left(\mathrm{O}_{2}\right)$ dynamics. The Iberian Upwelling System (IUS) is located in the northern limit of the eastern North Atlantic upwelling region, along the Iberian margin off Portugal and Spain. It presents a marked seasonality in the hydrodynamics and it is under the influence of water masses of different origin. Here, we describe the seasonal variability and spatial patterns of $\mathrm{O}_{2}$ in this system taking advantage of the 3-dimensional (3D) ocean model Regional Ocean Modeling System (ROMS). The model has been satisfactorily validated and has allowed a sound $3 \mathrm{D}$ description of the $\mathrm{O}_{2}$ dynamics of the coast and adjacent ocean, showing a strong seasonality in the $\mathrm{O}_{2}$ concentration of the upper water column. This seasonality is mainly caused by the deepening and shoaling of the seasonal mixed layer from winter to summer. $\mathrm{O}_{2}$ concentration is high during winter and reaches maximum values in spring due to the seasonal phytoplankton bloom. Minimum $\mathrm{O}_{2}$ values are obtained in summer and autumn. Additionally, the regional circulation of Eastern North Atlantic Central Water (ENACW) noticeably influences the $\mathrm{O}_{2}$ distribution. Over the shelf and slope, more variability is introduced

\footnotetext{
${ }^{*}$ Corresponding author

Email addresses: rosa.reboreda@ua.pt (Rosa Reboreda), cgcastro@iim.csic.es (Carmen G. Castro), xsalgado@iim.csic.es (Xosé A. Álvarez-Salgado), rita.nolasco@ua.pt (Rita Nolasco), ngfc@ua.pt (Nuno G. F. Cordeiro), henrique.queiroga@ua.pt (Henrique Queiroga), jdubert@ua.pt (Jesus Dubert)
} 
by the intense hydrodynamics of the upwelling season (spring/summer), the slope poleward flow (autumn/winter) and continental runoff.

Abbreviations $^{1}$

Keywords: Dissolved oxygen, modelling, ROMS, mineralization, upwelling, Eastern North Atlantic Central Water (ENACW). Regional index terms: East Atlantic, Iberian Margin, Portugal, Spain.

\section{Introduction}

The distribution and variability of dissolved oxygen $\left(\mathrm{O}_{2}\right)$ in the ocean 3 is controlled by physical and biological factors and the complex interactions ${ }_{4}$ between them. These include the large scale and regional circulation, vertical mixing, air-sea exchange, oxygen release by primary production and oxygen loss by zooplankton respiration/microbial mineralization. Highly productive eastern boundary coastal upwelling areas have received special attention to study oxygen trends and variability (e.g. the California Current System: Bograd et al., 2008) (review of oxygen trends in these and other oceanic regions in Keeling et al., 2010). The production and processing of considerable amounts of phytogenic organic matter in these areas coupled to the dynamics of the system is intimately related to the pronounced oxygen gradient between the equatorward-flowing surface layer and the compensating poleward-flowing subsurface layer, which provides interesting conditions to study the physical-biological interactions that govern oxygen dynamics (Bianucci and Denman, 2012).

The Iberian Upwelling System (IUS) is located in the northern limit of the eastern North Atlantic upwelling region (Barton et al., 1998; Wooster et al., 1976) (Fig. 1). It is characterized by a spring-summer upwelling season from April-May to September-October, when northerly winds off western

\footnotetext{
${ }^{1}$ IUP: Iberian Upwelling System.

PC: Portugal Current.

IC: Iberian Current.

IPC: Iberian Poleward Curent.

ENACWp: Eastern North Atlantic Central Water of subpolar origin.

ENACWt: Eastern North Atlantic Central Water of subtropical origin.

MW: Mediterranean Water.

MU: Mediterranean Undercurrent.

ROMS: Regional Ocean Modeling System.
} 
Iberia prevail, forcing an offshore Ekman transport and the upwelling of cold and nutrient rich water in the surface along the coast (Fraga, 1981; Relvas et al., 2007). This season is characterized by a high biological production (Álvarez-Salgado et al., 2002). During the rest of the year, the wind direction changes and a predominant surface poleward flow, the Iberian Poleward Current (IPC), is observable over the shelf edge and the slope, characterized by relatively warm and saline water (Haynes and Barton, 1990; Relvas et al., 2007). The region has the particularity of being well oxygenated due to the presence of Eastern North Atlantic Central Water (ENACW) in the main thermocline (Castro et al., 2000), consisting of a water branch of subpolar origin (ENACWp) and a water branch of subtropical origin (ENACWt) (Fiuza, 1984; Rios et al., 1992). The IPC transports northwards relatively low oxygen/low nutrient ENACWt along the slope and outer shelf (ÁlvarezSalgado et al., 2003; Perez et al., 1993). In contrast, recently ventilated ENACWp is sometimes observed to slowly move southward from its subduction area north of $46^{\circ} \mathrm{N}$ due to density differences (Pollard and $\mathrm{Pu}, 1985$ ). At sea surface a weak southward flow known as the Portugal Current (PC) is often thought to exist in the northwestern part of the region (Peliz et al., 2005; Perez et al., 2001), which may influence the $\mathrm{O}_{2}$ distribution conveying oxygen rich water (Perez et al., 2001). Although, such southward flow seems to be quite variable and reversible east of $13^{\circ} \mathrm{W}$, with periods of dominant northward flow (Maze et al., 1997). Deeper in the water column, the presence of Mediterranean Water (MW) is characterized by a conspicuous salinity maximum and $\mathrm{O}_{2}$ minimum spreading northwards close to the continental slope (Fiuza et al., 1998; Perez et al., 1993).

Given the described seasonal hydrodynamics and the influence of water masses of different origin, coupled physical-biogeochemical ocean modelling arises as a useful tool to study the spatial and temporal patterns of variability along the Atlantic Iberian margin. This approach can help to understand the complex interactions between the physical and biogeochemical mechanisms controlling oxygen variability (Bianucci and Denman, 2012; Deutsch et al., 2006). Furthermore, although numerical models of future global change scenarios predict a significant $\mathrm{O}_{2}$ decline (Keeling et al., 2010), the current confidence in these projections is limited (Gruber, 2011). Therefore, an appropriate understanding of the present situation is a mandatory first step to move forward into exploring future trends in the biogeochemical dynamics of any ecosystem.

This is the first study devoted to describe the seasonal and spatial vari- 
ability of $\mathrm{O}_{2}$ concentration in the Atlantic Iberian margin, taking advantage of an ocean model and some available observations. For that, we use a highresolution configuration of the Regional Ocean Modeling System (ROMS) coupled to a NPZD + O2 (Nitrate-Phytoplankton-Zooplankton-Detritus + Oxygen) biogeochemical model to simulate the three-dimensional (3D) seasonal oxygen dynamics in the western Iberian margin (Fig. 1). ROMS has been widely used to model the hydrodynamics of the region (e.g. Nolasco et al., 2013; Otero et al., 2008; Peliz et al., 2007), which gives a good base to explore $\mathrm{O}_{2}$ distribution using the biogeochemical model of ROMS. In the following sections we describe the model configuration and data used for validation of the model, we present the validation of model results and we do a characterization of the seasonal $\mathrm{O}_{2}$ distribution in the western Iberian shelf and adjacent ocean.

\section{Model setup, data and methods}

\subsection{Hydrodynamic model}

The seasonal dynamics of the IUS was simulated with the oceanic model Regional Ocean Modeling System (ROMS) (Haidvogel et al., 2008; Penven et al., 2006; Shchepetkin and McWilliams, 2005). ROMS is a 3D ocean circulation model with free-surface, vertical terrain-following coordinates, and horizontal orthogonal curvilinear coordinates. ROMS is based in the Boussinesq and hydrostatic approximations to solve the imcopressible primitive equations. It is coupled with advection/diffusion schemes for potential temperature, salinity and biological tracers, as well as a non linear equation of state. The advection scheme of Marchesiello et al. (2009) was used, which involves the split of advection and diffusion as a biharmonic operator, i.e., no explicit diffusion was implemnted. ROMS can be configured in high resolution to resolve coastal areas and regional seas at the mesoscale level. We implemented a high-resolution configuration for the western Iberian margin using two off-line nested domains, as described in Nolasco et al. (2013). The reader is referred to the latter for the validation of the hydrodynamic configuration of the model and for a description of the mean circulation and currents. Similar configurations of the model have been used in the region (Oliveira et al., 2009; Peliz et al., 2007, 2009). The large domain has $1 / 10^{\circ}$ $(\sim 9 \mathrm{~km})$ horizontal resolution and 30 vertical s-levels, in order to resolve the large-scale circulation features, such as the Azores Current. The highresolution nested domain, our target region of study, includes the coastal 
and adjacent oceanic region from the Strait of Gibraltar to northwest Iberia (Galicia) $\left(34^{\circ} \mathrm{N}-46^{\circ} \mathrm{N} ; \sim 1200 \times 600 \mathrm{~km}\right)$ (Fig. 1) and has horizontal resolution of $1 / 27^{\circ}(\sim 3 \mathrm{~km})$ and 60 vertical s-levels $(188 \times 389 \times 60$ grid $)$ in order to properly resolve the Mediterranean undercurrent (MU).

The large domain was initialized with temperature and salinity climatologies from Conkright et al. (2002), which also provided the open boundary conditions. The surface was forced with monthly climatological wind stress and fluxes of heat and freshwater from the Comprehensive OceanAtmosphere dataset (COADS; da Silva et al., 1994). Initial velocities were zero and monthly geostrophic velocities (referenced to $1200 \mathrm{~m}$ ) and Ekman velocities were calculated from the climatologies and applied along the lateral boundaries. The Mediterranean outflow was introduced as a nudging condition as described in Peliz et al. (2007). This configuration was run for 15 years, and it was validated by a comparison of mean eddy kinetic energy maps with AVISO altimetry data, with a methodology similar to that described by (Peliz et al., 2007).

The high-resolution nested domain (Fig. 1) was thus initialized and the boundary conditions provided by the large domain described above. The exchange of Atlantic and Mediterranean waters at the Strait of Gibraltar was explicitly represented in the high resolution domain by the imposition of vertical profiles of temperature, salinity and zonal velocity at the strait, similarly to (Peliz et al., 2007). The process of entrainment of ENACW with the MU was also parameterized by increasing the viscosity and diffusivity coefficients. The surface forcing was the same used in the large domain, i.e. the COADS climatology. The nested domain was run for 6 years, having reached a stable equilibrium solution in the 3rd year, until the Mediterranean water was in equilibrium and adjusted along the western and northern Iberian margin. The month of January of the 7 th year run was chosen to initialize the biogeochemical model described in section 2.2, which ran for 9 years.

In addition to the climatological simulation described above, a realistic simulation of the period May 2001 - April 2002 was performed using the same two-nested domains configuration. The surface forcing for that period was extracted from NCEP 2 reanalysis for air-sea fluxes (Kanamitsu et al., 2002) provided by the NOAA (http://www.esrl.noaa.gov/psd/) and QuickSCAT surface wind reanalysis $(2001-2008)$ at $0.5^{\circ} \times 0.5^{\circ}$ spatial resolution provided by CERSAT (http://www.ifremer.fr/cersat). The year 2001 was initialized from 1st January for the nested domain, using initial conditions from the climatological run (9th year) for the physical and biogeochemical variables. 
The physical boundary conditions were provided by a realistic simulation of 2001-2002 for the large domain, whereas the biogeochemical boundary conditions were climatological, as will be described in the next section.

The freshwater continental runoff from the main rivers of the region was included with monthly climatological discharge values (Río-Barja and Rodríguez-Lestegás, 1992) or, when available, realistic discharges for 20012002 provided by Instituto Nacional da Água (INAG) (http://inag.pt) (available for the three main rivers: Minho, Douro, and Tagus).

\subsection{Biogeochemical model}

Biogeochemical simulations were performed with a $N P Z D+\mathrm{O}_{2}$ model (Nitrate-Phytoplankton-Zooplankton-Detritus + Oxygen) coupled to ROMS. The NPZD model was a simple 4-components nitrogen based biogeochemical model based in that developed by Fasham et al. (1990) computing the mentioned state variables in mmol $\mathrm{N} \mathrm{m}^{-3}$. $\mathrm{O}_{2}$ concentration (expressed in mmol $\mathrm{O}_{2} \mathrm{~m}^{-3}$ ) was computed in the model so that it was influenced by other biogeochemical variables, but $\mathrm{O}_{2}$ did not have an effect on them, as will be detailed below (Fig. 2).

The 3D time evolution of the concentration of any biogeochemical variable $\left(B_{i}\right)$ is influenced by diffusion, horizontal advection, vertical mixing and the biogeochemical processes that act as sink or source for the variable:

$$
\frac{\partial B_{i}}{\partial t}=\nabla \cdot K \nabla B_{i}-u \cdot \nabla_{h} B_{i}-\left(w+w_{\text {sink }}\right) \frac{\partial B_{i}}{\partial z}+S M S\left(B_{i}\right)
$$

Where $K$ is the eddy kinematic diffusivity tensor, $u$ is the horizontal velocity, $w$ and $w_{\text {sink }}$ are the vertical velocity and the vertical sinking rate of the biogeochemical variable, respectively, with the exception of zooplankton, nitrate, and $\mathrm{O}_{2}$ to which no sinking rate was attributed. The biogeochemical processes included in the source minus sink $(S M S)$ term are specific for each variable (Fig. 2), and the parameters used to represent them are listed in Table 1. Since $\mathrm{O}_{2}$ is the focus of our study, we next describe in more detail the sinks ands sources considered for this variable in the model. A detailed description of the sink and sources for the other biogeochemical variables can be found in Reboreda et al. (In press).

Oxygen is produced by photosynthesis during phytoplankton growth, so its production rate can be calculated from nitrate uptake using a Redfieldian $r_{\mathrm{O}_{2}: \mathrm{NO}_{3}}$ stoichiometric ratio. Zooplankton metabolism removes $\mathrm{O}_{2}$, and this is estimated from the excretion of nutrients to the environment. Bacterial 
mineralization of detritus to nutrients also removes $\mathrm{O}_{2}$. Since the model only has one nutrient compartment (nitrate), the mineralization process was simplified to a direct oxidation from detritus to nitrate, and the $\mathrm{O}_{2}$ loss was computed using again the $r_{\mathrm{O}_{2}: \mathrm{NO}_{3}}$ ratio. The sediment compartment was not included in the model, so the detritus reaching the seafloor was simply incorporated to the bottom layer of the model in the water column, where it mineralized to nitrate at the specified mineralization rate. This representation of detritus mineralization near the bottom was in agreement with the findings of Arístegui et al. (2009), showing that in the Iberian shelf most organic matter reaching the bottom during the upwelling period was oxidized in the nepheloid layer and not in the sediment. Gas exchange with the atmosphere at the ocean surface was introduced in the top cells of the model. Thus, the $\mathrm{O}_{2} S M S$ term takes the form:

$$
\begin{aligned}
S M S\left(O_{2}\right)= & \mu(P A R, T) \cdot \mu(N) \cdot P h y t \cdot r_{O_{2}: N O_{3}}-t_{Z_{\text {metab }}} Z o o \cdot r_{O_{2}: N_{\text {metab }}} \\
& -t_{D_{\text {remin }}} \text { Det } \cdot r_{O_{2}: N_{3}}+Q_{g e}\left(O_{2} s a t-O_{2}\right)
\end{aligned}
$$

where the first term in the right hand side of the equation accounts for $\mathrm{O}_{2}$ production by photosynthesis (phytoplankton growth). Phytoplankton growth rate $(\mu)$ is limited by light (photosynthetically available radiation: $P A R)$, temperature $(T)$ and nutrients $(N)$ using the equations $\mu(P A R, T)$ and $\mu(N)$ described in Reboreda et al. (In press), with $\mu(P A R, T)$ modified as in Gruber et al. (2006) to include a variable chlorophyll:C ratio $(\theta)$.

The second term in Equation 2 accounts for $\mathrm{O}_{2}$ loss by zooplankton respiration (basal metabolism), estimated from the excretion of nutrients to the environment, with $t_{Z_{\text {metab }}}$ the zooplankton specific excretion rate (Table 1). The third term of the equation formulates detritus mineralization as an $\mathrm{O}_{2}$ sink, with $t_{D_{\text {remin }}}$ the detrital mineralization to nitrate rate (Table 1). The stoichiometric ratios for photosynthesis/mineralization $\left(r_{\mathrm{O}_{2}: \mathrm{NO}_{3}}\right)$ and zooplankton respiration $\left(r_{\mathrm{O}_{2}: N_{\text {metab }}}\right)$ convert Nitrogen concentration to $\mathrm{O}_{2}$ concentration (Table 1 ).

The last term in Equation 2 represents the exchange of $\mathrm{O}_{2}$ with the atmosphere at the sea surface. This flux can be either to the ocean (source) or from the ocean to the atmosphere (sink), depending on whether the surface layer is under-saturated or over-saturated in $\mathrm{O}_{2}$. It is calculated after the biogeochemical reactions were calculated. The gas exchange rate of $\mathrm{O}_{2}$ is calculated as: 


$$
Q_{g e}=\frac{K_{v}}{\Delta z}
$$

where $\Delta z$ is the height of the top cell and $K_{v}$ is the gas transfer coefficient calculated as:

$$
K_{v}=0.31 \cdot u^{2} \cdot \sqrt{\frac{660}{S c}}
$$

with $u$ the wind speed and $S c$ the Schmidt number calculated after Wanninkhof (1992). The saturation concentration of oxygen $\left(\mathrm{O}_{2} \mathrm{sat}\right)$ is calculated in a separated subroutine.

Initial and boundary conditions for $\mathrm{O}_{2}$ and nitrate were supplied from climatological data of the World Ocean Atlas (WOA) 2009 (Garcia et al., 2010a,b). Seasonal (for depths down to $500 \mathrm{~m}$ ) and annual (depths below $500 \mathrm{~m}$ ) climatologies were used. Initial and boundary chlorophyll-a concentrations were attributed from SeaWiFS seasonal climatology. Seasonal vertical profiles were created from these surface concentrations using the algorithm of Morel and Berthon (1989). Phytoplankton and zooplankton initial and boundary data where derived from chlorophyll-a $(P h y t=0.5 \cdot C h l$; $\left.Z_{o o}=0.2 \cdot C h l\right)$ (Gruber et al., 2006). Detritus concentrations were not available from climatologies, so its initial and boundary values were introduced using a low, non-zero constant value $\left(0.02 \mathrm{mmol} \mathrm{N} \mathrm{m}^{-3}\right)$ (Koné et al., 2005; Reboreda et al., In press). Boundary conditions for all the biogeochemical variables were supplied seasonally (15th February for Winter, 15th May for Spring, 15th August for Summer, and 15th November for Autumn).

River inputs of nitrate and chlorophyll along the year were introduced as constants (see table 2 in Marta-Almeida et al., 2012). Also, a constant river input of oxygen was used $\left(125 \mathrm{mmol} \mathrm{O}_{2} \mathrm{~m}^{-3}\right)$, based on data from Ferreira et al. (2003).

The biogeochemical model, which runs as a module integrated in the ocean model, was run for 9 years. This configuration converges in 1-2 years as observed by the time evolution of the biogeochemical variables. Therefore, we let 3 years of spinup.

\subsection{Data series and methods}

Model results presented are seasonal averages over 6 years (4th to 9th climatological years). Seasonal averages correspond to winter (January, February, and March), spring (April, May, and June), summer (July, August, and September), and autumn (October, November and December). 
Apparent oxygen utilization $(A O U)\left(\mathrm{mmol} \mathrm{O}_{2} \mathrm{~m}^{-3}\right)$ was calculated from model outputs as:

$$
A O U=\mathrm{O}_{2} \text { sat }-\mathrm{O}_{2}
$$

where $\mathrm{O}_{2}$ is the dissolved oxygen concentration output from the model and $\mathrm{O}_{2}$ sat is the saturation concentration of oxygen calculated as a function of in situ model temperature and salinity (Weiss, 1970) (oxsat Matlab ${ }^{\circledR}$ routine from the Ocean toolbox by the Scripps Institution of Oceanography). Climatological seasonal means of $\mathrm{O}_{2}$ concentration and $A O U$ for comparison with model results were provided by the WOA 2009 dataset at onedegree resolution (Garcia et al., 2010a). The climatological data set does not contain $\mathrm{O}_{2}$ values on the shelf. Oxygen data from the shelf for model comparisons were obtained from a series of surveys carried out in the northwestern Iberian region by the Spanish "Consejo Superior de Investigaciones Científicas" (CSIC): (1) The cruises GALICIA VII (February-March 1984) (Fraga et al., 1985) and GALICIA IX (September 1986) (Fraga et al., 1987) were selected among a series of surveys carried out during the 80's, which constitute a comprehensive hydrographic dataset around the region, made available through a series of public reports; (2) Two stations off the NW Iberian coast sampled weekly between 15th May 2001 and 24th April 2002 in the framework of the DYBAGA (Dinámica y Biogeoquímica Anual en la costa GAllega) project (location in Fig. 8). They represent a shelf location ( 150 m depth) (sta. 3) and a slope location ( 1500 m depth) (sta. 5). More details about the analysis and interpretation of the biogeochemical data collected at these two stations can be found in Álvarez-Salgado et al. (2006) and Castro et al. (2006). DYBAGA time series of $\mathrm{O}_{2}$, temperature and salinity at the two stations were compared to the corresponding modelled time series for these variables for a specific simulation of the period May 2001-April 2002. Model values shown are averages for 3 days and 9 grid points around the geographic positions of the stations (a square of $\sim 0.1^{\circ} \times 0.1^{\circ}$ ).

A quantitative analysis of model skill in representing $O_{2}$ concentration at the surface was performed by calculating the percentage model bias (Pbias), i.e., the sum of model error normalized by the climatological data (Allen et al., 2007):

$$
\text { Pbias }=\frac{\sum\left(M_{t}-D_{t}\right)}{\sum D_{t}} \cdot 100
$$

were $M_{t}$ and $D_{t}$ are the modelled and observed values at time index t. $M_{t}$ is the mean of the last 6 years of model run and $D_{t}$ the climatological mean. 


\section{Results and discussion}

The ability of the coupled hydrodynamic-biogeochemical model to reproduce the 3D seasonal and event variability of $\mathrm{O}_{2}$ in the Iberian shelf and adjacent oceanic region (NE Atlantic) was explored. A first assessment is presented by comparing seasonal means of $\mathrm{O}_{2}$ at the sea surface with WOA climatological data (section 3.1). Next, $\mathrm{O}_{2}$ model results in the water column are evaluated along a meridional section at $10.5^{\circ} \mathrm{W}$. Additionally, the remineralized component of $\mathrm{O}_{2}$ in this section, i.e. the $A O U$ computed from model results, is compared with climatological $A O U$ (section 3.2). Finally, model results on the shelf are assessed by comparing the model to surveyed data in the northwestern (Galician) shelf, and the shelf-ocean interaction was explored using three cross-shelf model sections (section 3.3).

\subsection{Sea surface seasonal mean of $\mathrm{O}_{2}$ and surface model bias}

The seasonal trend of sea surface dissolved $\mathrm{O}_{2}$ was well reproduced by the model (Fig. 3). The highest $\mathrm{O}_{2}$ concentrations were obtained in spring, especially in the northwest oceanic region $\left(>265 \mathrm{mmol} \mathrm{O}_{2} \mathrm{~m}^{-3}\right)$, coinciding with the northeast Atlantic spring phytoplankton bloom. Winter $\mathrm{O}_{2}$ concentrations were also high in the region, with values above $250 \mathrm{mmol} \mathrm{O}_{2} \mathrm{~m}^{-3}$. This is an expected consequence of ventilation of the water column during winter mixing, as the upper mixed layer depth increases from $20 \mathrm{~m}$ in late summerearly autumn to $150 \mathrm{~m}$ between $40^{\circ} \mathrm{N}$ and $43^{\circ} \mathrm{N}$ (Álvarez-Salgado et al., 2003), and to more than $300 \mathrm{~m}$ North of $43^{\circ} \mathrm{N}$, in late winter (FebruaryMarch) (Arhan et al., 1994; Perez et al., 2005). The lowest $O_{2}$ concentrations at the sea surface were obtained in summer and autumn, corresponding to periods of intense thermal stratification and thus low oxygen solubility. The characteristic North to South latitudinal gradient was well captured by the model, with remarkable similarities in spring (Fig. 3). Average values of dissolved $\mathrm{O}_{2}$ concentration compared well with WOA climatological data for the four seasons.

Figure 4 shows the Pbias of the model at the sea surface for the four seasons. This analysis gives a measure of whether the model is systematically underestimating or overestimating the climatological data. The Pbias observed can be rated as very good, roughly between $\pm 2.5 \%$ in most of the domain for all periods. As a general trend, the model slightly underestimated climatological data in winter, spring and a bit more in summer, while it tended to slightly overestimate climatological data in autumn. 


\subsection{Seasonal mean of $\mathrm{O}_{2}$ and $A O U$ along a meridional section}

The North-to-South section at longitude $10.5^{\circ} \mathrm{W}$ (Fig. 1) shows that the model vertical distribution of $\mathrm{O}_{2}$ in the oceanic region is comparable to seasonal climatological data (Fig. 5). The general North-to-South vertical distribution of $\mathrm{O}_{2}$ consists of: 1) an upper layer $(\sim 0-400 \mathrm{~m})$ with a marked seasonal variation and a northward increase in $\mathrm{O}_{2}$ concentration; 2) an $\mathrm{O}_{2}$ minimum $\left(<200 \mathrm{mmol} \mathrm{O}_{2} \mathrm{~m}^{-3}\right)$ centred at about $1000 \mathrm{~m}$ depth, with wider vertical extension to the South; 3) a deep layer (>1500 m) showing almost nule seasonal variations and increasing $\mathrm{O}_{2}$ concentration with depth. Between $\sim 2000$ and $2500 \mathrm{~m}$ depth a tongue of high $\mathrm{O}_{2}$ concentration $\left(>250 \mathrm{mmol} \mathrm{O}_{2} \mathrm{~m}^{-3}\right.$ ) of northern origin, with slightly seasonal variation, was present. The seasonal variability and latitudinal gradient in the uppermost layer (roughly $\sim 0-100 \mathrm{~m}$ ) were the same described in the previous section, corresponding to the surface seasonal varying mixed layer, highly influenced by ocean-atmospheric interactions and biological activity (Mann and Lazier, 2006). Below this layer, the $\mathrm{O}_{2}$ distribution was related to the water masses present in the region, an extensive thermohaline description of which can be found in Fiuza et al. (1998), Fraga et al. (1982) and Rios et al. (1992).

Between $\sim 100-400 \mathrm{~m}$, the latitudinal and seasonal differences in $\mathrm{O}_{2}$ were related to the presence and variability of ENACW. The increase in $\mathrm{O}_{2}$ concentration to the North was related to ENACWp ( $\mathrm{S}<35.6)$, subducted into the North Atlantic $\left(>43^{\circ} \mathrm{N}\right)$, conveying high $\mathrm{O}_{2}$ concentration southwards due to its recent contact with atmosphere during winter mixing (Perez et al., $2005,1993)$. In the near surface of the southern part ENACWt $(\mathrm{S}>35.7)$ carried water with relatively low $\mathrm{O}_{2}$ concentration to the North (Perez et al., 2001, 1993). The vertical $\mathrm{O}_{2}$ minimum at $\sim 1000 \mathrm{~m}$ was averagely slightly above the salinity maximum of MW (Fig. 5). A similar position of the $\mathrm{O}_{2}$ minimum was observed by Perez et al. (1993) from $40^{\circ} \mathrm{N}$ to $47^{\circ} \mathrm{N}$ and Castro et al. (1998) in a section across $42^{\circ} \mathrm{N} . \mathrm{O}_{2}$ minima development is the result of the imbalance between physical ventilation and microbial mineralization processes (Gruber, 2011; Keeling et al., 2010). Some studies have suggested that the position of the $\mathrm{O}_{2}$ minimum between the ENACWp, slowly moving southward, and the MW flowing northward in the MU, corresponds to a level of slow motion between this two water masses, where longer residence times enhance the effect of mineralisation (Castro et al., 1998; Perez et al., 1993). Our results also pointed out to a prevailing position of the $\mathrm{O}_{2}$ minimum in the transition between ENACW and MW (i.e., above the salinity maximum). However this was not clearly associated to a minimum in the meridional ve- 
locity profile (data not shown). In fact, there was a prevalence of northward movement of both water masses. Thus, the position of the minimum maybe emphasized at the low motion level when an opposing advance of ENACW and MW occurs, as suggested in the literature, however this did not seem to be the prevailing situation. Still, the position of the minimum appeared to be result of a combination of slow water movement (there was a general trend for diminishing velocity with depth in the water column, continuing below the $\mathrm{O}_{2}$ minimum) and mineralization rates. We identified the position of the $\mathrm{O}_{2}$ minimum for the entire model domain and found that for most part of the region it was situated at an average depth between $800 \mathrm{~m}$ and $1000 \mathrm{~m}$ (maximum depth $1600 \mathrm{~m}$ ), except for a region in the southern part of the domain, where it was shallower. The uplift of the $\mathrm{O}_{2}$ minimum in this region, which can be appreciated in Figure 5 together with the uplift of the isohalines, was a consequence of the cyclonic circulation in the Gulf of Cadiz known as the beta-plume (Peliz et al., 2007). The cyclonic circulation seemed to cause a higher variability in the vertical $\mathrm{O}_{2}$ minimum along the year. The average depth of the $\mathrm{O}_{2}$ minimum in the domain (excluding shelf values) was $870 \pm 36 \mathrm{~m}$. Over the shelf, $\mathrm{O}_{2}$ minimum was associated to the bottom. Mean annual values of $\mathrm{O}_{2}$ concentration at the minimum were between 190 and $200 \mathrm{mmol} \mathrm{O}_{2} \mathrm{~m}^{-3}$ for most of the model domain, with slightly lower values to the South. Minimum $\mathrm{O}_{2}$ concentration within the shelf did not fall below $200 \mathrm{mmol} \mathrm{O}_{2} \mathrm{~m}^{-3}$. Below $1500 \mathrm{~m}$, the $\mathrm{O}_{2}$ concentration increased again with the presence of North Atlantic Deep Water (NADW). Within this water mass, the tongue of high $\mathrm{O}_{2}$ concentration from the North matches the tongue of Labrador Sea Water (LSW) observed in the region (Castro et al., 1998; Fiuza et al., 1998).

The $\mathrm{O}_{2}$ Pbias of the model for the vertical meridional section described above is shown in Figure 6. For most depths the modelled $\mathrm{O}_{2}$ Pbias was very good, between $\pm 2.5 \%$, as obtained for the surface $\mathrm{O}_{2}$. Excepcionally, the modelled $\mathrm{O}_{2}$ was more than $2.5 \%$ lower than the climatological value in the southern central waters, and more than $2.5 \%$ higher than the climatological value in the northern upper water column and in three deep cores at about 1000 and $1500 \mathrm{~m}$. The higher Pbias core at about $1000 \mathrm{~m}$ was about coincident with the position of the MW salinity maximum, sugesting a slight overestimation of $\mathrm{O}_{2}$ in the MW or, otherwise, a slightly different position of the MW maximum in the model. In fact, the analysis of the thermohaline properties of this model configuration presented in Nolasco et al. (2013) pointed out to a position of the salinity maximum of MW about $200 \mathrm{~m}$ above 
the climatological position (1000 m instead of $1200 \mathrm{~m}$ ), which could also be perceived from the isohalines depicted in Figure 5.

The ability of the model to reproduce the impact of aerobic mineralization on the vertical distribution of dissolved $\mathrm{O}_{2}$ in the region was evaluated comparing seasonal $A O U$ calculated from model results and climatological $A O U$ data, for the vertical section at $10.5^{\circ} \mathrm{W}$ (Figs. 1 and 7 ). The $A O U$ from the model reproduced well the climatological observations for the four seasons. As described for $\mathrm{O}_{2}, A O U$ showed seasonal variability in the surface layer $(<200 \mathrm{~m})$, where biological activity is high, whereas it stayed rather stable in deeper layers. Negative values of $\mathrm{AOU}\left(\mathrm{O}_{2}\right.$ concentration higher than $\mathrm{O}_{2}$ saturation concentration) were found in the surface all the year round, except in winter, when low surface water temperatures give high $\mathrm{O}_{2}$ saturation concentrations and the photosynthetic activity of phytoplankton is quite reduced (Álvarez-Salgado et al., 2003). AOU increased with depth (from 0 to $\sim 100 \mathrm{mmol} \mathrm{O}_{2} \mathrm{~m}^{-3}$ ), reflecting aerobic mineralization of sinking organic matter and the presence of deep older water masses. The tongue of high $\mathrm{O}_{2}$ concentration described before and attributed to LSW showed lower $A O U\left(<80 \mathrm{mmol} \mathrm{O}_{2} \mathrm{~m}^{-3}\right)$ than the surrounding waters.

\subsection{Characterization of $\mathrm{O}_{2}$ distribution over the shelf}

\subsubsection{Model comparison with observed data in the Galician shelf}

We based our evaluation of the model results for the shelf on comparisons with data referred in section 2.3 (Fig. 8) and observations referred in the literature. Spatial and seasonal distributions of surface dissolved $\mathrm{O}_{2}$ obtained during the CICLOS cruises along the western $\left(37^{\circ} \mathrm{N}-41.8^{\circ} \mathrm{N}\right)$ and southern $\left(7.5^{\circ} \mathrm{W}-9^{\circ} \mathrm{W}\right)$ Portuguese shelf (August/November 1985; January/March 1986) were reported in Moita (2001). These data showed a seasonal trend from the highest $\mathrm{O}_{2}$ concentrations in spring $(\sim 9 \mathrm{mg} / \mathrm{L})$ and the lowest in autumn $(\sim 8 \mathrm{mg} / \mathrm{L})$ (corresponding to $\sim 280$ and $250 \mathrm{mmol} \mathrm{O}_{2} \mathrm{~m}^{-3}$, respectively), which compares fairly well with model values (Fig. 3). Model results show the highest shelf $\mathrm{O}_{2}$ concentrations in summer, instead of spring, presumably related to the upwelling-associated phytoplankton blooms. High values of dissolved $\mathrm{O}_{2}$ were also found by Moita (2001) in summer (August), associated with upwelling centres. Thus, the disagreement in the timing of the highest concentration between the model and CICLOS data might be explained by the fact that the model simulation is climatological, i.e. it gives a spatial and time long-term average over the period, while data represent a synoptic situation, so that a particular upwelling event is likely to be weaker 
(or stronger) than the average situation over the upwelling season. The model trend to higher $\mathrm{O}_{2}$ concentrations in the Northern shelf than in the Southern shelf was also observed by Moita (2001) in January and August.

Figure 8 shows comparisons between surface dissolved $O_{2}$ in the Galician shelf for the cruises GALICIA VII (February-March 1984) and GALICIA IX (September 1986) and the corresponding climatological model averages for March and September. The two cruises represent two contrasting situations regarding surface $\mathrm{O}_{2}$ concentration, with GALICIA VII showing a typical late winter situation with high $\mathrm{O}_{2}$ concentration and GALICIA IX showing a typical autumn situation with low $\mathrm{O}_{2}$ concentration. Model values were high near the coast in March $\left(>260 \mathrm{mmol} \mathrm{O}_{2} \mathrm{~m}^{-3}\right)$, and this was also observed in the GALICIA VII data, although higher $\mathrm{O}_{2}$ values were observed $\left(>270 \mathrm{mmol} \mathrm{O}_{2} \mathrm{~m}^{-3}\right.$ ) and they extended further offshore. This could be a consequence of slightly upwelling-favourable conditions during the cruise (Álvarez-Salgado et al., 2003). Model shelf values in September were comparable to the observations made in the cruise GALICIA IX, except for some high $\mathrm{O}_{2}$ values observed in the northwestern Galician shelf. These high values may be attributable to high chlorophyll concentrations $\left(>1 \mathrm{mg} \mathrm{m}^{-3}\right)$ found in the region at the time of the cruise (Álvarez-Salgado et al., 1997).

Figures 9 and 10 present a 1-year time series of observed and modelled $\mathrm{O}_{2}$, temperature and salinity at the two stations described in section 2.3 (see position in Fig. 8), off the NW Iberian coast (note different depth scales). At both the middle shelf (sta. 3) and off the shelf edge (sta. 5) the model was able to reproduce the seasonal and short term variability of the thermohaline properties and $\mathrm{O}_{2}$ concentration in the water column, with very similar values to observed ones. Seven hydrographic periods were described by Nieto-Cid et al. (2004) and Álvarez-Salgado et al. (2006) for the sampling period May 2001-April 2002 at sta. 3, based on offshore Ekman transport, continental runoff and water column stratification. Similar hydrographic situations were described by Castro et al. (2006) for sta. 5, though with lower temporal variability, as expected for an offshore location. Here, we summarize their description of these periods and comment on the ability of the model to reproduce them and the observed $\mathrm{O}_{2}$ concentration:

1) Upwelling season (15th May-25th September): Regardless of upwelling favourable northerly winds, thermal stratification of the upper water column prevailed at sta. 5, with model temperatures very similar to those observed (Fig. 9b and e). Throughout this period $\mathrm{O}_{2}$ concentration in the seasonal thermocline remained high $\left(240-260 \mathrm{mmol} \mathrm{O}_{2} \mathrm{~m}^{-3}\right)$ with model values 
slightly higher than observations (Fig. 9a and d). This high $\mathrm{O}_{2}$ concentration was related to a subsurface chlorophyll maximum (not shown). A subsurface salinity maximum was observed beneath the seasonal thermocline and identified as a core of poleward flowing ENACWt by Castro et al. (2006), which was not detected in the model until the end of September (Fig. 9c and $\mathrm{f}$ ). Over the shelf (sta. 3), the hydrographic situation along this period was characterized by upwelling episodes with short intervals of wind relaxation and marked thermal stratification until late August (Fig. 10b and e). These episodes were more clearly separated in the model due to its higher temporal resolution. Oxygen concentration within the seasonal thermocline was high following upwelling episodes $\left(>260 \mathrm{mmol} \mathrm{O}_{2} \mathrm{~m}^{-3}\right)$ in both observed and modelled values (Fig. 10a and d), and was related to phytoplankton blooms as in sta. 5. Colder underlying ENACW showed values between $220-240 \mathrm{mmol} \mathrm{O}_{2} \mathrm{~m}^{-3}$, with model values $\sim 10 \mathrm{mmol} O_{2} \mathrm{~m}^{-3}$ higher. This seemed to be related with the differences identified in thermohaline properties between the model and observations, with colder and less salty deeper ENACW in the model suggesting a higher proportion of ENACWp $\left(O_{2}\right.$ rich $)$ in the water mass than observed. The presence of such ENACW in the shelf was a consequence of the referred lack in the model of the subsurface core of poleward flowing ENACWt in the vicinities of the slope (sta. 5) (lower $\mathrm{O}_{2}$ concentration). Between the 28th August and 18th September there was a strong upwelling event with subsequent uplift of cold and salty ENACW water (Fig 10b, c, e, and f), which also brought relatively low $\mathrm{O}_{2}$ concentration water closer to the surface (Fig. 10a and d).

2) Downwelling (25th September-30th October): At the end of September there was a shift in the wind regime to the characteristic southwesterlies of this period, which caused a downwelling episode at sta. 3 (Fig. 10b, and e), whereas at sta. 5 the water column remained stratified (Fig. 9b and e). Castro et al. (2006) attributed this stratification to intense continental runoff from the adjacent Rías Baixas, given the low salinity lens observed on the surface (Fig. 9c). The contribution of the Minho river estuary, located a few $\mathrm{km}$ to the south, was also likely. The model reproduced the same low salinity lens, though with somewhat higher salinity values (Fig. 9f). The use in the model of monthly climatological discharges for the Verdugo river $\left(\sim 40 \mathrm{~m}^{3} \mathrm{~s}^{-1}\right.$ for October), flowing into the adjacent Ría de Vigo (and for the other main rivers flowing into the Rías Baixas), introduced a modelled continental runoff lower than the estimated daily runoff referred in Nieto-Cid et al. (2004) for this month, which reached an intense peak of $\sim 300 \mathrm{~m}^{3} \mathrm{~s}^{-1}$. 
The southwesterlies transported warm $\left(>17^{\circ} \mathrm{C}\right)$ and salty oceanic water to the vicinities of the shelf (Fig. $9 \mathrm{~b}$ and $\mathrm{c}$ ), which was reproduced by the model (Fig. 9e and $\mathrm{f}$ ). There was an influx of this warm and relatively low $\mathrm{O}_{2}$ concentration $\left(<240 \mathrm{mmol} \mathrm{O}_{2} \mathrm{~m}^{-3}\right)$ oceanic water into the shelf (Fig. 10a, b, $\mathrm{d}$, and e).

3) Transient autumn upwelling period (6th-20th November): The anomalously strong northerly winds of November favoured vertical homogenization of the water column by inducing an upwelling situation at both sta. 3 and 5 (Figs. 9 and 10). The low salinity lens observed at sta. 3 (Fig. 10c) was not evident in the model (Fig. 10f), presumably due to the mentioned use of monthly climatological discharges to the adjacent Ría de Vigo, which could not reproduce the peak of intense runoff showed in Nieto-Cid et al. (2004) and Álvarez-Salgado et al. (2006) in late October. Most probably the low salinity lens followed the typical evolution described by Otero et al. (2008), being confined to the shelf during the downwelling event, and expanding offshore under the upwelling conditions. This out-of-season upwelling event promoted $\mathrm{O}_{2}$-poor but inorganic nitrogen-rich bottom-shelf ENACW to the surface layer (Álvarez-Salgado et al., 2006) leading to a phytoplankton bloom (not shown) and the concomitant increase in $\mathrm{O}_{2}$ concentration (>240 mmol $\mathrm{O}_{2} \mathrm{~m}^{-3}$ ) (Fig. 10a and d) (Fig. 9a and d).

4) Arrival of the IPC to the shelf (27th November-13th February): The reversal in wind direction to southwesterlies brought the presence of warm and saline ENACWt conveyed by the IPC to the continental slope (sta. 5) (Fig. 9b and c), and the shelf (sta. 3) (Fig. 10b and c). At sta. 5, ENACWt in the model was slightly colder and less saline than observations and, accordingly, showed higher $\mathrm{O}_{2}$ concentration (Fig. 9). Note the coincidence of the salinity maximum of ENACWt and the $\mathrm{O}_{2}$ minimum (Fig. 9a and c). Surface model results indicated that this ENACWt came frequently from an eastward recirculation of the IPC associated with an anticyclonic eddy (at the end of January, for instance, Fig. 11). A similar eddy conveying ENACWt was observed in the same area (between $41.5^{\circ} \mathrm{N}$ and $42^{\circ} \mathrm{N}$ ) by Fiuza et al. (1998) in May 1993. ENACWt values of temperature and salinity over the shelf were similar in the model and in observations, except for slightly higher salinities in the model in February (Fig. 10b, c, e, and f). Oxygen values were $\sim 10 \mathrm{mmol} \mathrm{O}_{2} \mathrm{~m}^{-3}$ higher in the model than in observations all along this period (Fig. 10a and d). This overestimation of the $\mathrm{O}_{2}$ concentration in the model may be caused by the lack of a sediment compartment to account for the sediment oxygen demand. As explained in the model description 
(section 2.2), this simplification was considered appropriated for the region since most organic matter reaching the bottom is oxidized in the nepheloid layer and not in the sediment (Arístegui et al., 2009). Still, as autumn is a time of intense in situ mineralization, it is possible that the contribution of sediment for organic matter oxidation becomes more relevant for this period. Ferrón et al. (2009) showed that for the inner Gulf of Cadiz (SE Iberian shelf) sediment oxygen uptake could range from 9 to $27 \mathrm{mmol} \mathrm{O}_{2} \mathrm{~m}^{-2} \mathrm{~d}^{-1}$. Another possibility is that the overestimation detected may be related to the absence of phytoplankton respiration in the model, which would affect $\mathrm{O}_{2}$ concentration related to chlorophyll maxima. Although, a test performed revealed that introducing phytoplankton respiration (as 20\% of primary production) would just reduce about $2 \mathrm{mmol} \mathrm{O}_{2} \mathrm{~m}^{-3}$, as an averge over the domain. From the model we could identify that the ENACWt present in the shelf at this latitude $\left(42^{\circ} \mathrm{N}\right)$ was conveyed northwards either by the IPC circulating over the slope and entering the shelf or often by a branch of IPC circulating entirely within the shelf, as that detected at the beginning of February (salinity maximum, delayed in the model relative to observations) (Fig. 10c and f). The surface model results illustrated clearly the downstream $\mathrm{O}_{2}$ enrichment of the IPC by mixing with ENACWp and with shelf waters, in a similar way as described by Perez et al. (2001) (Fig. 11).

5) Winter mixing (20th February-26th March): There was an increase in $\mathrm{O}_{2}$ concentration enhanced by winter mixing of the water column at both stations ( $\sim 200 \mathrm{~m}$ at sta. 5 and reaching the bottom depth over the shelf at sta. 3), which enhanced the entry of $\mathrm{O}_{2}$ from the atmosphere. Modelled $\mathrm{O}_{2}$ concentration in the shelf was very similar to observations (Fig. 10a and d).

6) Spring stratification (2nd-24th April): Spring stratification developed under upwelling favourable winds at the end of the study period (Fig. 10b and e) (Fig. 9b and e). There was a clear uplift of the isotherms at sta. 5 in the model which was not so evident in observations. These upwelling conditions, together with the incipient spring thermal stratification, induced a phytoplankton bloom (not shown) with a subsequent increase in $\mathrm{O}_{2}$ concentration produced by photosynthesis in both the model and observations (Fig. 10a and d) (Fig. 9a and d).

\subsubsection{Shelf-ocean interaction}

The seasonal variability of dissolved $\mathrm{O}_{2}$ in the Iberian shelf and the shelfocean interactions have been studied along three cross-shelf sections at $42^{\circ}$ $\mathrm{N}, 40^{\circ} \mathrm{N}$ and $38^{\circ} \mathrm{N}$ from model results. These three locations were chosen 
because they represent three different zones of the Atlantic Iberian shelf with contrasting characteristics: (1) The northern shelf from Cape Finisterre to the River Minho $\left(\sim 43^{\circ} \mathrm{N}-41.5^{\circ} \mathrm{N}\right)$, off the Galician coast, being medium width and presenting an irregular coastline due to the presence of the Rías Baixas, four large coastal embayments (>30 km length, $>2.5 \mathrm{~km}^{3}$ volume); (2) The wide shelf between the river Minho and Cape Roca $\left(\sim 41.5^{\circ} \mathrm{N}\right.$ $39^{\circ} \mathrm{N}$ ); and (3) The Southern narrow shelf between Cape Roca and Cape São Vicente $\left(\sim 37^{\circ} \mathrm{N}-39^{\circ} \mathrm{N}\right)$. Both areas (2) and (3) show a regular coastline with meridional orientation. These differences along the Iberian shelf and their effect on biogeochemical cycles dynamics, namely on in situ oxidation of organic mater vs. offshore export have been studied by Álvarez-Salgado et al. (1997) based on several surveys in the Northwest Iberian region.

Figure 12 shows model seasonal averages of $\mathrm{O}_{2}$ along the three cross-shelf sections. As a general seasonal trend, $\mathrm{O}_{2}$ concentration decreased in shelf waters during summer and autumn, except in the upper water column affected by the subsurface chlorophyll maximum (not shown). This subsurface $\mathrm{O}_{2}$ maximum was located at about $50 \mathrm{~m}$ depth offshore and raised to the surface near the coast, showing lower $\mathrm{O}_{2}$ concentration towards the south. The summer/autumn seasonal decrease has been attributed to the intensification of mineralization during these seasons (Álvarez-Salgado et al., 1997, 1993; Castro et al., 2006). The real autumn $\mathrm{O}_{2}$ concentration is expected to be slightly lower than the concentration shown in figure 12, given the overestimation detected in autumn modelled values in the previous section. An increase in $\mathrm{O}_{2}$ concentration was observed during winter, and it continued increasing throughout spring. Winter mixing favours high $\mathrm{O}_{2}$ concentrations on the shelf by deepening of the mixed layer depths. Remnants of winter mixed layer can still be present during spring (Fiuza et al., 1998). Also, the spring phytoplankton bloom provides $\mathrm{O}_{2}$ to surface layers through photosynthesis. Oxygen concentration on the shelf tended to decrease from North to South, which is an expected consequence of the hydrography of the region, where the southern shelf is more influenced by the presence of ENACWt, typically carrying lower $\mathrm{O}_{2}$ concentration (Álvarez-Salgado et al., 1997).

Seasonal anomalies of modelled $\mathrm{O}_{2}$ and nitrate concentration (relative to annual means) are shown in Fig. 13. The previously described seasonal trend in $\mathrm{O}_{2}$ concentration on the shelf is also evident here (Fig. 13, upper panel). Oxygen anomalies over the shelf tended to be positive in winter and spring and negative in summer and autumn (excluding the upper mixed layer, which was more affected by saturation equilibrium with the atmosphere 
and phytoplankton blooms). Oxygen and nitrate anomalies were opposite, an indication of organic matter degradation and subsequent nitrification to nitrate. A strong negative $\mathrm{O}_{2}$ anomaly (positive nitrate anomaly) was noticeable in autumn, with maximum values in the near bottom water of the outer shelf. This points out to high recycling of organic matter at this position, i.e., mineralization of sinking particulate organic matter (detritus) out of the photic layer (Álvarez-Salgado et al., 1997). The onset of downwelling favourable conditions occurs in autumn, after the summer upwelling season, accompanied by the autumn plankton bloom, influencing the shelf biogeochemistry (Álvarez-Salgado et al., 2003). Downwelling is enhanced by the shift in the winds regime (from northeasterlies to southwesterlies) and by the presence of the IPC flow over the shelf edge and the slope. The presence of the IPC over the slope in autumn was described for Fig. 10 in the previous section. Model results support the hypothesis that the presence of the IPC limits the offshore export of particulate organic matter and thus enhances mineralization of organic matter over the shelf through recycling near the bottom shelf and on top of the sediments (Álvarez-Salgado et al., 1997, 2003). This effect was more intense in the cross-shelf section at $40^{\circ} \mathrm{N}$, where the shelf is wider as noted by Álvarez-Salgado et al. (1997) (Fig. 13). In summer, the upwelling conditions favour a prevailing southward circulation over the shelf and slope (upwelling jet) and an offshore Ekman transport promoting organic matter export from the shelf. Also in summer, the negative $\mathrm{O}_{2}$ anomaly (positive nitrate anomaly) near the bottom shelf indicates mineralization of sinking organic matter from the surface coastal plankton bloom (Fig. 13). This intensified mineralization extends offshore, as a consequence of the enhanced export of organic matter to the adjacent ocean mediated by filaments (Álvarez-Salgado et al., 2007; Cravo et al., 2010). In addition, there were noticeable differences in positive $\mathrm{O}_{2}$ anomalies (negative nitrate anomalies) of the shelf-slope from North to South; the anomalies tended to be reduced to the South, suggesting less offshore export of organic matter in the northern sections, i.e., where the shelf is wider (Fig. 13). In this sense, a more efficient recycling would be expected where the shelf is wider (Álvarez-Salgado et al., 1997). The winter situation is opposite to the summer situation, as low primary production along the season keeps positive $\mathrm{O}_{2}$ anomalies (negative nitrate anomalies) near the bottom shelf, indicating lower mineralization rates (Fig. 13). The negative $\mathrm{O}_{2}$ anomaly (positive nitrate anomaly) near the surface indicates the absence of the $\mathrm{O}_{2}$ produced (the presence of the nitrate not consumed) by photosynthesis. 


\section{Summary and conclusions}

Reliable predictions of the evolution of ocean oxygen content in future global change scenarios should be based on the ability of models to reasonably reproduce the actual conditions (Gruber, 2011). The model used in this work has been quite satisfactorily validated and allowed a sound 3D description of the variability and spatial distribution of $\mathrm{O}_{2}$ along western Iberian coast and adjacent ocean. The Atlantic Iberian margin shows a strong seasonality in the $\mathrm{O}_{2}$ concentration of the upper water column. In the adjacent ocean, seasonality is mainly controlled by solar radiation and heat exchange with the atmosphere, which drives the deepening and shoaling of the seasonal mixed layer from winter to summer. Ventilation of the water column in winter $\left(\sim\right.$ February-March) provides a massive influx of atmospheric $\mathrm{O}_{2}$ to the water column up to $150 \mathrm{~m}$ to the south of $43^{\circ} \mathrm{N}$ and more than $300 \mathrm{~m}$ to the north of that latitude. $\mathrm{O}_{2}$ continues increasing during spring due to the seasonal phytoplankton bloom, reaching maximum values by that time. Minimum $\mathrm{O}_{2}$ values are obtained in summer and autumn, periods of strong thermal stratification and $\mathrm{O}_{2}$ loss by mineralization. Still, a subsurface $\mathrm{O}_{2}$ maximum at about $50 \mathrm{~m}$, associated to the subsurface chlorophyll maximum, remains along the season. Additionally, the regional circulation of central waters influences the $\mathrm{O}_{2}$ distribution, mainly by the interplay between the southward displacement of oxygen-rich ENACWp and the northward transport of oxygen-poor ENACWt by the IPC. Deeper in the water column, at $\sim 800-1000 \mathrm{~m}$, there is a conspicuous $\mathrm{O}_{2}$ minimum nearly coincident with the salinity maximum of the MW. The described seasonal pattern generally applies to the shelf region, but here more variability is introduced by the intense hydrodynamics of the upwelling season (spring/summer), the poleward flow of ENACWt over the slope and shelf in autumn/winter and continental runoff. These influence also primary production and mineralization patterns and, thus, $\mathrm{O}_{2}$ concentration. During upwelling episodes cold and nitrate rich ENACW from 150-250 $\mathrm{m}$ depth in the adjacent ocean raises to the photic layer of the shelf carrying lower $\mathrm{O}_{2}$ concentrations than the remnant coastal waters. However, its nitrate content rapidly induces phytoplankton blooms that raise the $\mathrm{O}_{2}$ concentration. The shift to prevailing downwelling conditions in autumn/winter with the arrival of the IPC to the shelf and slope brings lower $\mathrm{O}_{2}$ concentration, although ENACWt transported by the IPC over the slope becomes more $\mathrm{O}_{2}$ rich as it displaces poleward because of mixing with the surrounding oxygen richer shelf surface waters. The presence of 
the IPC over the slope limits the off-shelf export of organic matter, causing intense remineralisation near the bottom shelf, decreasing $O_{2}$ concentration there. Evident latitudinal gradients exist related to the regional circulation and the differences in shelf extension and topography.

\section{Acknowledgements}

This work was supported by Fundação para a Ciência e a Tecnologia (FCT), Portugal, through the PhD grant SFRH/BD/33388/2008 to R.R. The study is a contribution to project "RAIA-Observatorio oceánico del margen ibérico (INTERREG, programa de cooperación transfronteriza EspañaPortugal)", which financed a fellowship to N.C. X.A.A.S. was also funded by the project CAIBEX, grant No CTM2007-66408-C02-01/MAR. We wish to acknowledge Spanish Consejo Superior de Investigaciones Científicas (CSIC) for making available the oceanographic data recovered in the cruises GALICIA VII and GALICIA IX through public reports. We also thank CSIC for providing the data of the two stations sampled within the frame of the project DYBAGA, grant No MAR99-1039-C02-01. River data were public available at Portuguese Instituto Nacional da Água (INAG) and European Environment Agency (EEA) websites.

\section{References}

Allen, J. I., Holt, J. T., Blackford, J., Proctor, R., 2007. Error quantification of a high-resolution coupled hydrodynamic-ecosystem coastal-ocean model: Part 2. Chlorophyll-a, nutrients and SPM. Journal of Marine Systems 68, 381-404.

Álvarez-Salgado, X. A., Aristegui, J., Barton, E. D., Hansell, D. A., 2007. Contribution of upwelling filaments to offshore carbon export in the subtropical Northeast Atlantic Ocean. Limnology and Oceanography 52 (3), $1287-1292$.

Álvarez-Salgado, X. A., Beloso, S., Joint, I., Nogueira, E., Chou, L., Perez, F. F., Groom, S., Cabanas, J. M., Rees, A. P., Elskens, M., 2002. New production of the NW Iberian shelf during the upwelling season over the period 1982-1999. Deep-Sea Research Part I-Oceanographic Research Papers 49 (10), 1725-1739. 
Álvarez-Salgado, X. A., Castro, C. G., Perez, F. F., Fraga, F., 1997. Nutrient mineralization patterns in shelf waters of the western Iberian upwelling. Continental Shelf Research 17 (10), 1247-1270.

Álvarez-Salgado, X. A., Figueiras, F. G., Perez, F. F., Groom, S., Nogueira, E., Borges, A., Chou, L., Castro, C. G., Moncoiffe, G., Rios, A. F., Miller, A. E. J., Frankignoulle, M., Savidge, G., Wollast, R., 2003. The Portugal coastal counter current off NW Spain: new insights on its biogeochemical variability. Progress in Oceanography 56 (2), 281-321.

Álvarez-Salgado, X. A., Nieto-Cid, M., Gago, J., Brea, S., Castro, C. G., Doval, M. D., Perez, F. F., 2006. Stoichiometry of the degradation of dissolved and particulate biogenic organic matter in the NW Iberian upwelling. Journal of Geophysical Research-Oceans 111, C07017, doi:10.1029/2004jc002473.

Álvarez-Salgado, X. A., Roson, G., Perez, F. F., Pazos, Y., 1993. Hydrographic variability off the Rias Baixas (NW Spain) during the upwelling season. Journal of Geophysical Research-Oceans 98 (C8), 14447-14455.

Arhan, M., de Verdière, A. C., Memery, L., 1994. The eastern boundary of the subtropical North-Atlantic. Journal of Physical Oceanography 24 (6), $1295-1316$.

Arístegui, J., Barton, E. D., Álvarez-Salgado, X. A., Santos, A. M. P., Figueiras, F. G., Kifani, S., Hernández-León, S., Mason, E., Machú, E., Demarcq, H., 2009. Sub-regional ecosystem variability in the Canary Current upwelling. Progress in Oceanography 83, 33-48.

Barton, E. D., Aristegui, J., Tett, P., Canton, M., Garcia-Braun, J., Hernandez-Leon, S., Nykjaer, L., Almeida, C., Almunia, J., Ballesteros, S., Basterretxea, G., Escanez, J., Garcia-Weill, L., Hernandez-Guerra, A., Lopez-Laatzen, F., Molina, R., Montero, M. F., Navarro-Perez, E., Rodriguez, J. M., van Lenning, K., Velez, H., Wild, K., 1998. The transition zone of the Canary Current upwelling region. Progress in Oceanography 41 (4), 455-504.

Bianucci, L., Denman, K. L., 2012. Carbon and oxygen cycles: Sensitivity to changes in environmental forcing in a coastal upwelling system. Journal of Geophysical Research-Biogeosciences 117 (G1), doi: 10.1029/2011JG001849. 
Bograd, S. J., Castro, C. G., Di Lorenzo, E., Palacios, D. M., Bailey, H., Gilly, W., Chavez, F. P., 2008. Oxygen declines and the shoaling of the hypoxic boundary in the California Current. Geophysical Research Letters 35 (12), doi: 10.1029/2008GL034185.

Castro, C. G., Nieto-Cid, M., Alvarez-Salgado, X. A., Perez, F. F., 2006. Local remineralization patterns in the mesopelagic zone of the Eastern North Atlantic, off the NW Iberian Peninsula. Deep-Sea Research Part I-Oceanographic Research Papers 53 (12), 1925-1940.

Castro, C. G., Perez, F. F., Alvarez-Salgado, X. A., Fraga, F., 2000. Coupling between the thermohaline, chemical and biological fields during two contrasting upwelling events off the NW Iberian Peninsula. Continental Shelf Research 20 (2), 189-210.

Castro, C. G., Perez, F. F., Holley, S. E., Rios, A. F., 1998. Chemical characterisation and modelling of water masses in the Northeast Atlantic. Progress in Oceanography 41 (3), 249-279.

Conkright, M., Locarnini, R. A., Garcia, H. E., O’Brien, T. D., Boyer, T. P., Stephens, C., Antonov, J., 2002. World ocean atlas 2001: Objective analyses, data statistics, and figures. Tech. rep., National Oceanographic Data Center Report.

Cravo, A., Relvas, P., Cardeira, S., Rita, F., Madureira, M., Sánchez, R., 2010. An upwelling filament off southwest Iberia: Effect on the chlorophyll a and nutrient export. Continental Shelf Research 30 (15), 1601-1613.

da Silva, A., Young, A., Levitus, S., 1994. Atlas of surface marine data 1994, volume 1: Algorithms and procedures.

Deutsch, C., Emerson, S., Thompson, L., 2006. Physical-biological interactions in North Pacific oxygen variability. Journal of Geophysical ResearchOceans 111 (C9).

Fasham, M. J. R., Ducklow, H. W., Mckelvie, S. M., 1990. A nitrogen-based model of plankton dynamics in the oceanic mixed layer. Journal of Marine Research 48 (3), 591-639.

Ferreira, J., Simas, T., Schifferegger, K., Lencart e Silva, J., 2003. Identification of sensitive areas and vulnerable zones in transitional and coastal 
Portuguese systems. application of the United States national estuarine eutrophication assessment to the Minho, Lima, Douro, Ria de Aveiro, Mondego, Tagus, Sado, Mira, Ria Formosa and Guadiana systems. technical report. Tech. rep.

Ferrón, S., Alonso-Pérez, F., Ortega, T., Forja, J., 2009. Benthic respiration on the northeastern shelf of the gulf of cádiz (sw iberian peninsula). Marine Ecology Progress Series 392, 69-80.

Fiuza, A. F. G., 1984. Hidrologia e dinámica das águas costeiras de Portugal. phd thesis. Ph.D. thesis, Universidade de Lisboa, Portugal.

Fiuza, A. F. G., Hamann, M., Ambar, I., del Rio, G. D., Gonzalez, N., Cabanas, J. M., 1998. Water masses and their circulation off western Iberia during May 1993. Deep-Sea Research Part I-Oceanographic Research Papers 45 (7), 1127-1160.

Fraga, F., 1981. Upwelling off the Galician coast, Northwest Spain. In: Richards, S. A. (Ed.), Coastal upwelling series. Vol. 1. AGU, Washington DC, pp. 176-182.

Fraga, F., Figueiras, F. G., Prego, R., Perez, F. F., Rios, A. F., 1987. Campaña Galicia IX oceánica. Tech. rep.

Fraga, F., Mouriño, C., Manríquez, M., 1982. Las masas de agua en la costa de Galicia: junio-octubre. Tech. rep.

Fraga, F., Mouriño, C., Pérez, F. F., Rios, A. F., Marrasé, C., 1985. Campaña Galicia VII. Tech. rep.

Garcia, H., Locarnini, R. A., Boyer, T., Antonov, J., Baranova, O., Zweng, M., Johnson, D., 2010a. World ocean atlas 2009, volume 3: Dissolved Oxygen, Apparent Oxygen Utilization, and Oxygen Saturation.

Garcia, H. E., Locarnini, R. A., Boyer, T., Antonov, J., Zweng, M., Baranova, O., Johnson, D., 2010b. World Ocean Atlas 2009, volume 4: Nutrients (phosphate, nitrate, silicate).

Gruber, N., 2011. Warming up, turning sour, losing breath: ocean biogeochemistry under global change. Philosophical Transactions of the Royal Society a-Mathematical Physical and Engineering Sciences 369 (1943), 19801996. 
Gruber, N., Frenzel, H., Doney, S. C., Marchesiello, P., McWilliams, J. C., Moisan, J. R., Oram, J. J., Plattner, G. K., Stolzenbach, K. D., 2006. Eddy-resolving simulation of plankton ecosystem dynamics in the California Current System. Deep-Sea Research Part I-Oceanographic Research Papers 53 (9), 1483-1516.

Haidvogel, D. B., Arango, H., Budgell, W. P., Cornuelle, B. D., Curchitser, E., Di Lorenzo, E., Fennel, K., Geyer, W. R., Hermann, A. J., Lanerolle, L., Levin, J., McWilliams, J. C., Miller, A. J., Moore, A. M., Powell, T. M., Shchepetkin, A. F., Sherwood, C. R., Signell, R. P., Warner, J. C., Wilkin, J., 2008. Ocean forecasting in terrain-following coordinates: Formulation and skill assessment of the regional ocean modeling system. Journal of Computational Physics 227 (7), 3595-3624.

Haynes, R., Barton, E. D., 1990. A poleward flow along the Atlantic coast of the Iberian Peninsula. Journal of Geophysical Research-Oceans 95 (C7), $11425-11441$.

Kanamitsu, M., Ebisuzaki, W., Woollen, J., Yang, S. K., Hnilo, J. J., Fiorino, M., Potter, G. L., 2002. Ncep-Doe Amip-Ii Reanalysis (R-2). Bulletin of the American Meteorological Society 83 (11), 1631-1643.

Keeling, R. F., Kortzinger, A., Gruber, N., 2010. Ocean deoxygenation in a warming World. Annual Review of Marine Science 2, 199-229.

Koné, V., Machu, E., Penven, P., Andersen, V., Garcon, V., Fréon, P., Demarcq, H., 2005. Modeling the primary and secondary productions of the southern Benguela upwelling system: A comparative study through two biogeochemical models. Global Biogeochemical Cycles 19 (4), GB4021, doi:10.1029/2004GB002427.

Mann, K. H., Lazier, J. R. N., 2006. Dynamics of marine ecosystems. WileyBlackwell, Oxford.

Marchesiello, P., Debreu, L., Couvelard, X., 2009. Spurious diapycnal mixing in terrain-following coordinate models: The problem and a solution. Ocean Modelling 26 (3-4), 156 - 169.

Marta-Almeida, M., Reboreda, R., Rocha, C., Dubert, J., Nolasco, R., Cordeiro, N., Luna, T., Rocha, A., Lencart e Silva, J. D., Queiroga, H., 
Peliz, A., Ruiz-Villarreal, M., 2012. Towards operational modeling and forecasting of the iberian shelves ecosystem. PLoS ONE 7 (5), e37343.

Maze, J. P., Arhan, M., Mercier, H., 1997. Volume budget of the eastern boundary layer off the Iberian Peninsula. Deep-Sea Research Part IOceanographic Research Papers 44 (9-10), 1543-1574.

Moita, M. T., 2001. Estrutura, variabilidade e dinámica do fitoplâncton na costa de Portugal continental. PhD Thesis, Faculdade de Ciências da Universidade de Lisboa, Portugal.

URL http://www.inrb.pt/fotos/editor2/Tese_Teresa_Moita.pdf

Morel, A., Berthon, J. F., 1989. Surface pigments, algal biomass profiles, and potential production of the euphotic layer: Relationships reinvestigated in view of remote-sensing application. Limnology and Oceanography 34, $1545-1562$.

Nieto-Cid, M., Alvarez-Salgado, X. A., Brea, S., Perez, F. F., 2004. Cycling of dissolved and particulate carbohydrates in a coastal upwelling system (NW Iberian Peninsula). Marine Ecology-Progress Series 283, 39-54.

Nolasco, R., Pires, A., Cordeiro, N., Cann, B., Dubert, J., 2013. A highresolution modeling study of the western iberian margin mean and seasonal upper ocean circulation. Ocean Dynamics 63 (9-10), 1041-1062.

Oliveira, P. B., Nolasco, R., Dubert, J., Moita, T., Peliz, A., 2009. Surface temperature, chlorophyll and advection patterns during a summer upwelling event off central Portugal. Continental Shelf Research 29 (5-6), $759-774$.

Otero, P., Ruiz-Villarreal, M., Peliz, A., 2008. Variability of river plumes off Northwest Iberia in response to wind events. Journal of Marine Systems 72 (1-4), 238-255.

Peliz, A., Dubert, J., Marchesiello, P., Teles-Machado, A., 2007. Surface circulation in the Gulf of Cadiz: Model and mean flow structure. Journal of Geophysical Research-Oceans 112, C11015, doi:10.1029/2007jc004159.

Peliz, A., Dubert, J., Santos, A. M. P., Oliveira, P. B., Le Cann, B., 2005. Winter upper ocean circulation in the Western Iberian Basin - 
fronts, eddies and poleward flows: an overview. Deep-Sea Research Part I-Oceanographic Research Papers 52 (4), 621-646.

Peliz, A., Marchesiello, P., Santos, A. M. P., Dubert, J., Teles-Machado, A., Marta-Almeida, M., Le Cann, B., 2009. Surface circulation in the Gulf of Cadiz: 2. Inflow-outflow coupling and the Gulf of Cadiz slope current. Journal of Geophysical Research-Oceans 114 (C3), doi:10.1029/2008JC004771.

Penven, P., Debreu, L., Marchesiello, P., McWilliams, J. C., 2006. Evaluation and application of the ROMS 1-way embedding procedure to the central California upwelling system. Ocean Modelling 12 (1-2), 157-187.

Perez, F. F., Castro, C. G., Alvarez-Salgado, X. A., Rios, A. F., 2001. Coupling between the Iberian basin - scale circulation and the Portugal boundary current system: a chemical study. Deep-Sea Research Part IOceanographic Research Papers 48 (6), 1519-1533.

Perez, F. F., Castro, C. N. G., Rios, A. F., Fraga, F., 2005. Chemical properties of the deep winter mixed layer in the Northeast Atlantic (40-47 degrees N). Journal of Marine Systems 54 (1-4), 115-125.

Perez, F. F., Mourino, C., Fraga, F., Rios, A. F., 1993. Displacement of water masses and remineralization rates off the Iberian Peninsula by nutrient anomalies. Journal of Marine Research 51 (4), 869-892.

Pollard, R. T., Pu, S., 1985. Structure and circulation of the upper Atlantic ocean Northeast of the Azores. Progress in Oceanography 14 (1-4), 443462 .

Reboreda, R., Nolasco, R., Castro, C. G., Alvarez-Salgado, X. A., Cordeiro, N. G., Queiroga, H., Dubert, J., In press. Seasonal cycle of plankton production in the iberian margin based on a high resolution ocean model. Journal of Marine Systems.

Relvas, P., Barton, E. D., Dubert, J., Oliveira, P. B., Peliz, A., da Silva, J. C. B., Santos, A. M. P., 2007. Physical oceanography of the western Iberia ecosystem: Latest views and challenges. Progress in Oceanography $74(2-3), 149-173$.

Río-Barja, F., Rodríguez-Lestegás, F., 1992. Os ríos galegos. Morfoloxía e réxime. Consello da Cultura Galega, Santiago de Compostela. 
Rios, A. F., Perez, F. F., Fraga, F., 1992. Water masses in the upper and middle North-Atlantic ocean East of the Azores. Deep-Sea Research Part a-Oceanographic Research Papers 39 (3-4A), 645-658.

Shchepetkin, A. F., McWilliams, J. C., 2005. The regional oceanic modeling system (ROMS): a split-explicit, free-surface, topography-followingcoordinate oceanic model. Ocean Modelling 9 (4), 347-404.

Wanninkhof, R., 1992. Relationship between wind-speed and gas-exchange over the ocean. Journal of Geophysical Research-Oceans 97 (C5), 73737382 .

Weiss, R. F., 1970. Solubility of Nitrogen, Oxygen and Argon in water and seawater. Deep-Sea Research 17 (4), 721-735.

Wooster, W. S., Bakun, A., Mclain, D. R., 1976. Seasonal upwelling cycle along Eastern boundary of North-Atlantic. Journal of Marine Research 34 (2), 131-141. 
Figure 1: Region of study and nested model grids. Dashed line indicates the position of the meridional section at $10.5^{\circ} \mathrm{W}$.

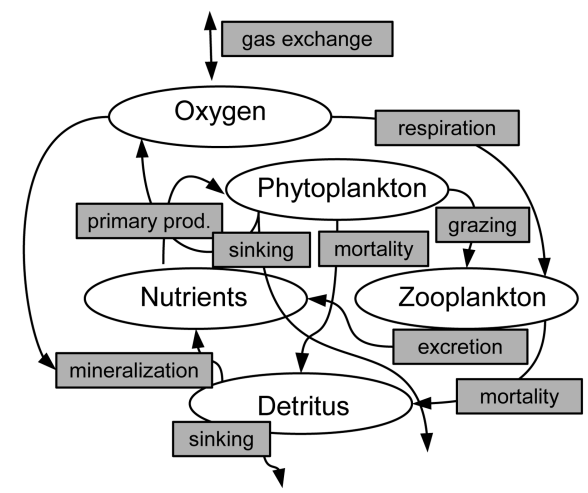

Figure 2: Diagram of the $N P Z D+\mathrm{O}_{2}$ model. Model state variables (nitrate, phytoplankton, zooplankton and detritus) are represented in terms of nitrogen concentration. 


\begin{tabular}{|c|c|c|c|}
\hline \multicolumn{2}{|c|}{ Parameter } & \multirow{2}{*}{$\begin{array}{l}\text { Value } \\
0.04\end{array}$} & \multirow{2}{*}{$\begin{array}{l}\text { Unit } \\
\mathrm{m}^{-1}\end{array}$} \\
\hline $\mathrm{K}_{\mathrm{w}}$ & Light attenuation in seawater & & \\
\hline $\mathrm{K}_{\text {chla }}$ & Light attenuation by chlorophyll & 0.024 & $\left(\mathrm{~m}^{2} \mathrm{mg} \mathrm{Chla}\right)^{-1}$ \\
\hline$\alpha$ & Initial slope of the P-I curve & 1 & $\mathrm{mg} \mathrm{C}\left(\mathrm{mg} \mathrm{ChlaW} \mathrm{m}^{-2} \mathrm{~d}\right)^{-1}$ \\
\hline$r_{\text {C:NPhyt }}$ & $\mathrm{C}: \mathrm{N}$ ratio for phytoplankton & 6.625 & $\operatorname{mol~C}(\operatorname{mol~N})^{-1}$ \\
\hline $\mathrm{r}_{\mathrm{O} 2: \mathrm{Nm} \text { tab }}$ & $\mathrm{O}_{2}: \mathrm{N}$ ratio for zooplankton metabolism & 6.625 & $\mathrm{~mol} \mathrm{O}_{2}(\mathrm{~mol} \mathrm{~N})^{-1}$ \\
\hline $\mathrm{r}_{\mathrm{O} 2: \mathrm{NO} 3}$ & $\mathrm{O}_{2}: \mathrm{N}$ ratio for photosynthesis/mineralization & 8.625 & $\mathrm{~mol} \mathrm{O}_{2}(\mathrm{~mol} \mathrm{~N})^{-1}$ \\
\hline$\theta_{\max }$ & Maximum cellular chlorophyll:C ratio & 0.03 & mg Chla (mg C) $)^{-1}$ \\
\hline $\mathrm{K}_{\mathrm{NO3}}$ & Half-saturation for phytoplankton $\mathrm{NO}_{3}$ uptake & 1.5 & $\mathrm{mmol} \mathrm{N} \mathrm{m} \mathrm{m}^{-3}$ \\
\hline $\mathrm{K}_{\mathrm{P}}$ & Zooplankton half-saturation constant for ingestion & 1 & $\operatorname{mmol~} \mathrm{N} \mathrm{m}^{-3}$ \\
\hline$g_{\max }$ & Maximum zooplankton growth rate & 0.9 & $\mathrm{~d}^{-1}$ \\
\hline$\beta$ & Zooplankton assimilation coefficient & 0.75 & n.d. \\
\hline $\mathrm{m}_{\mathrm{PD}}$ & Phytoplankton mortality rate & 0.03 & $\mathrm{~d}^{-1}$ \\
\hline$m_{\mathrm{ZD}}$ & Zooplankton mortality rate & 0.1 & $\mathrm{~d}^{-1}$ \\
\hline$t_{\text {Zmetab }}$ & Zooplankton specific excretion rate & 0.1 & $\mathrm{~d}^{-1}$ \\
\hline$t_{\text {Dremin }}$ & Detrital mineralization to $\mathrm{NO}_{3}$ rate & 0.05 & $\mathrm{~d}^{-1}$ \\
\hline$W_{P}$ & Sinking velocity for phytoplankton & 0.5 & $\mathrm{~m} \mathrm{~d}^{-1}$ \\
\hline$W_{D}$ & Sinking velocity for detritus & 5 & $\mathrm{~m} \mathrm{~d}^{-1}$ \\
\hline
\end{tabular}

Table 1: Parameter values of the $N P Z D+O_{2}$ model. 

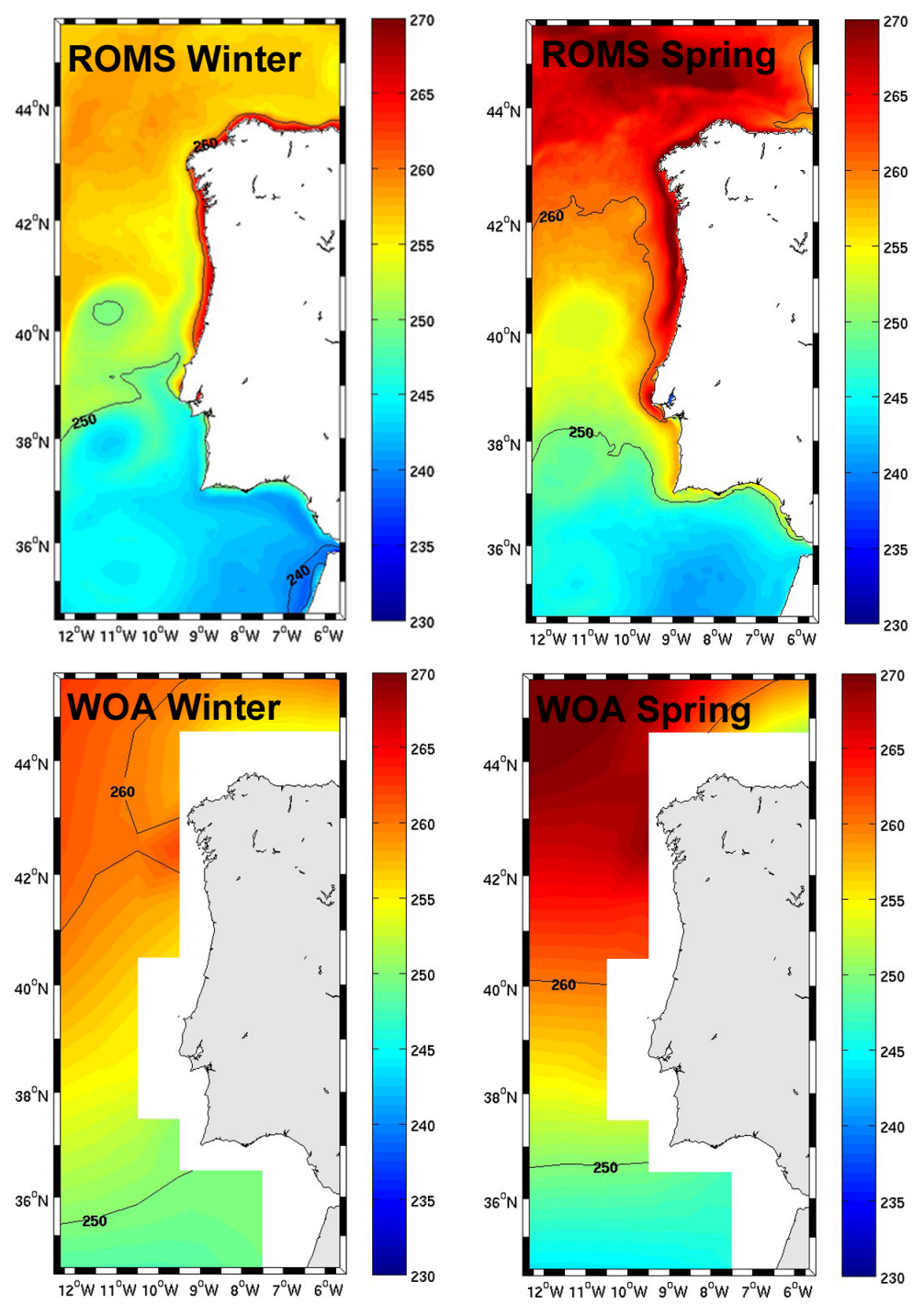

Figure 3: Seasonal mean of sea surface dissolved oxygen $\left(\mathrm{mmol} \mathrm{O}_{2} \mathrm{~m}^{-3}\right)$ from model results (ROMS) and from climatological data (WOA 2009). Modelled values correspond to six years averages of surface oxygen. WOA values are based on observations from 1921 to 2008. 


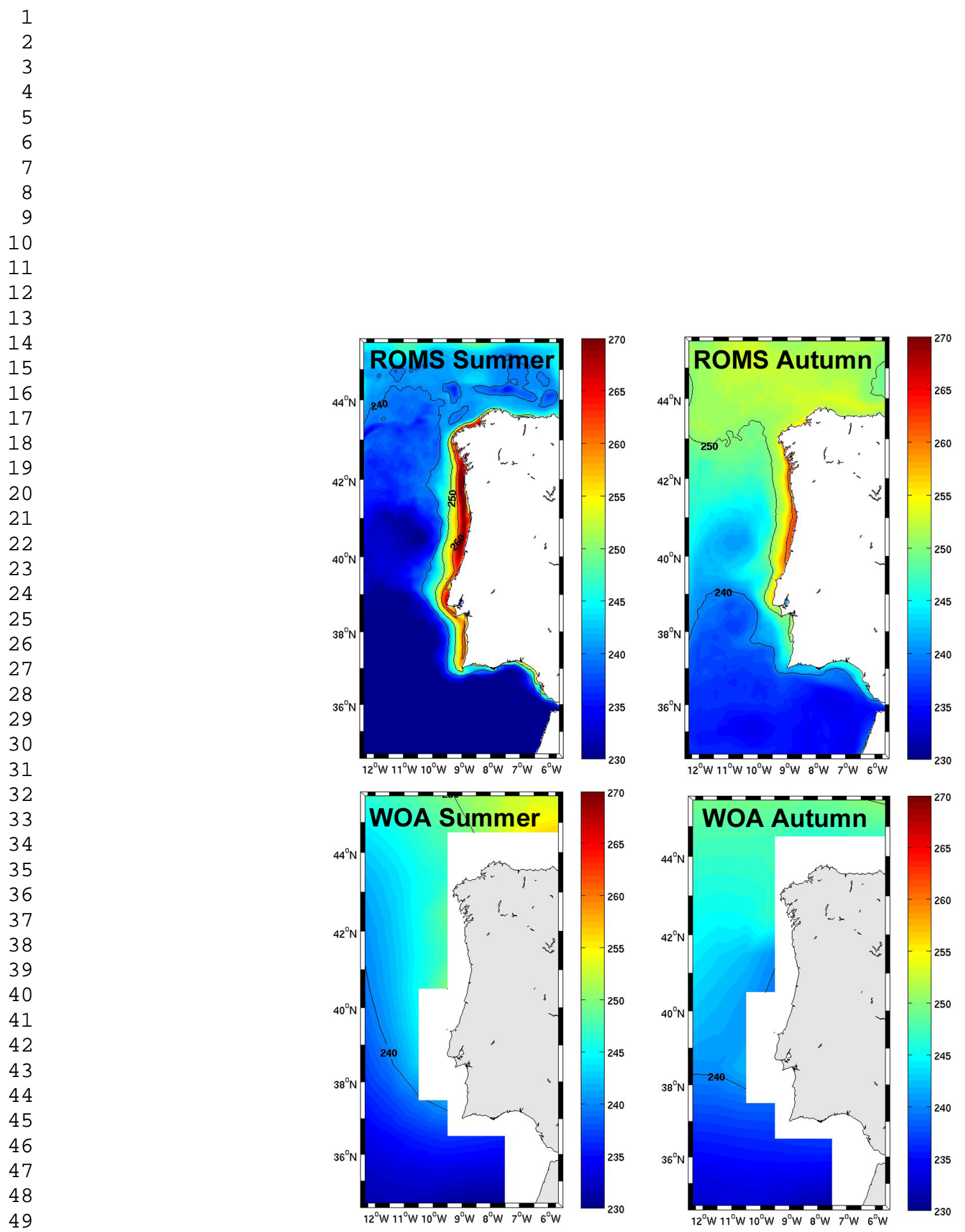

Figure 3: Continued. 

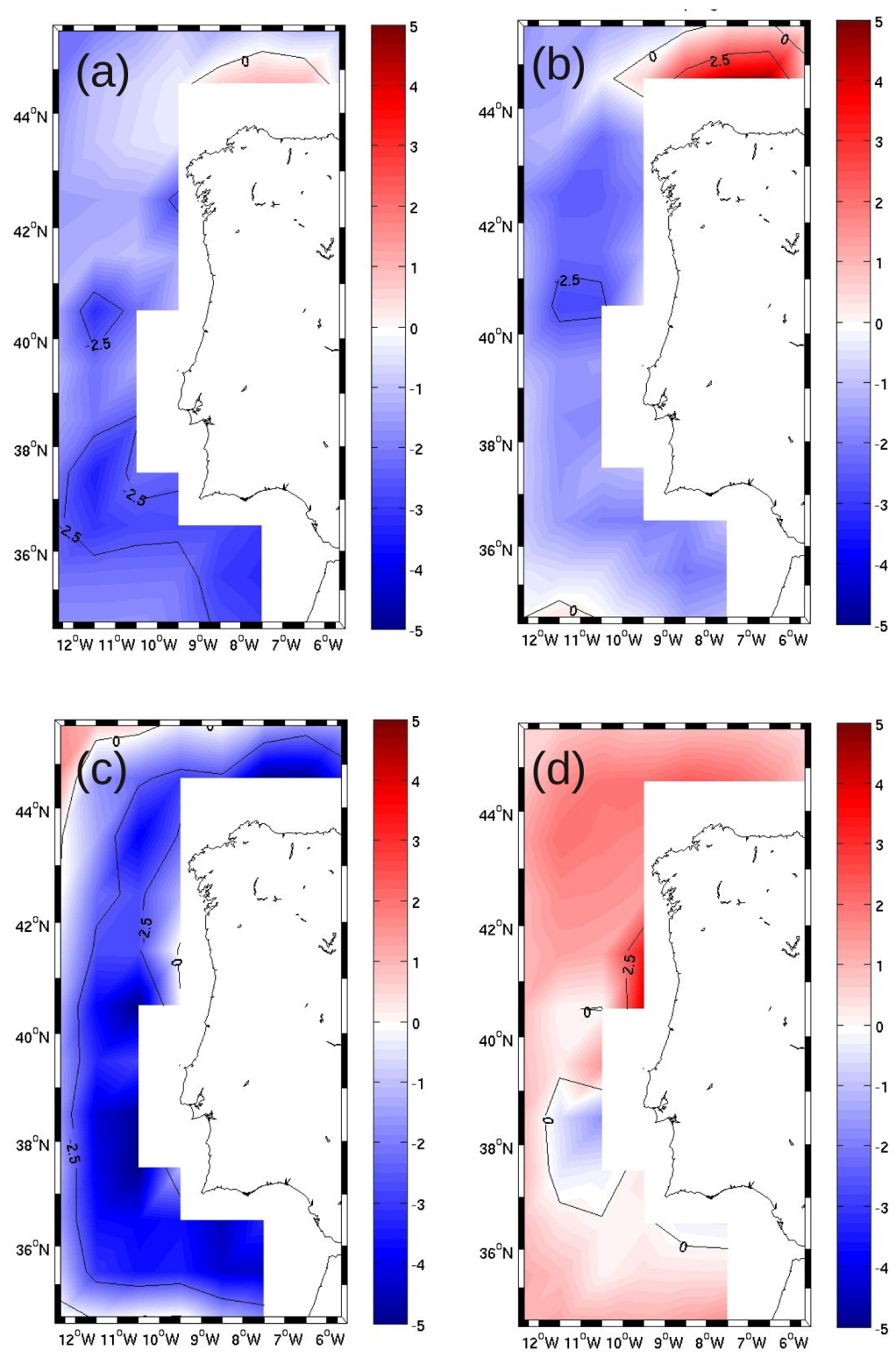

Figure 4: Pbias (\%) of seasonal mean of dissolved oxygen at the sea surface from ROMS model results vs. climatological data (WOA 2009): (a) winter; (b) spring; (c) summer; (d) autumn. 

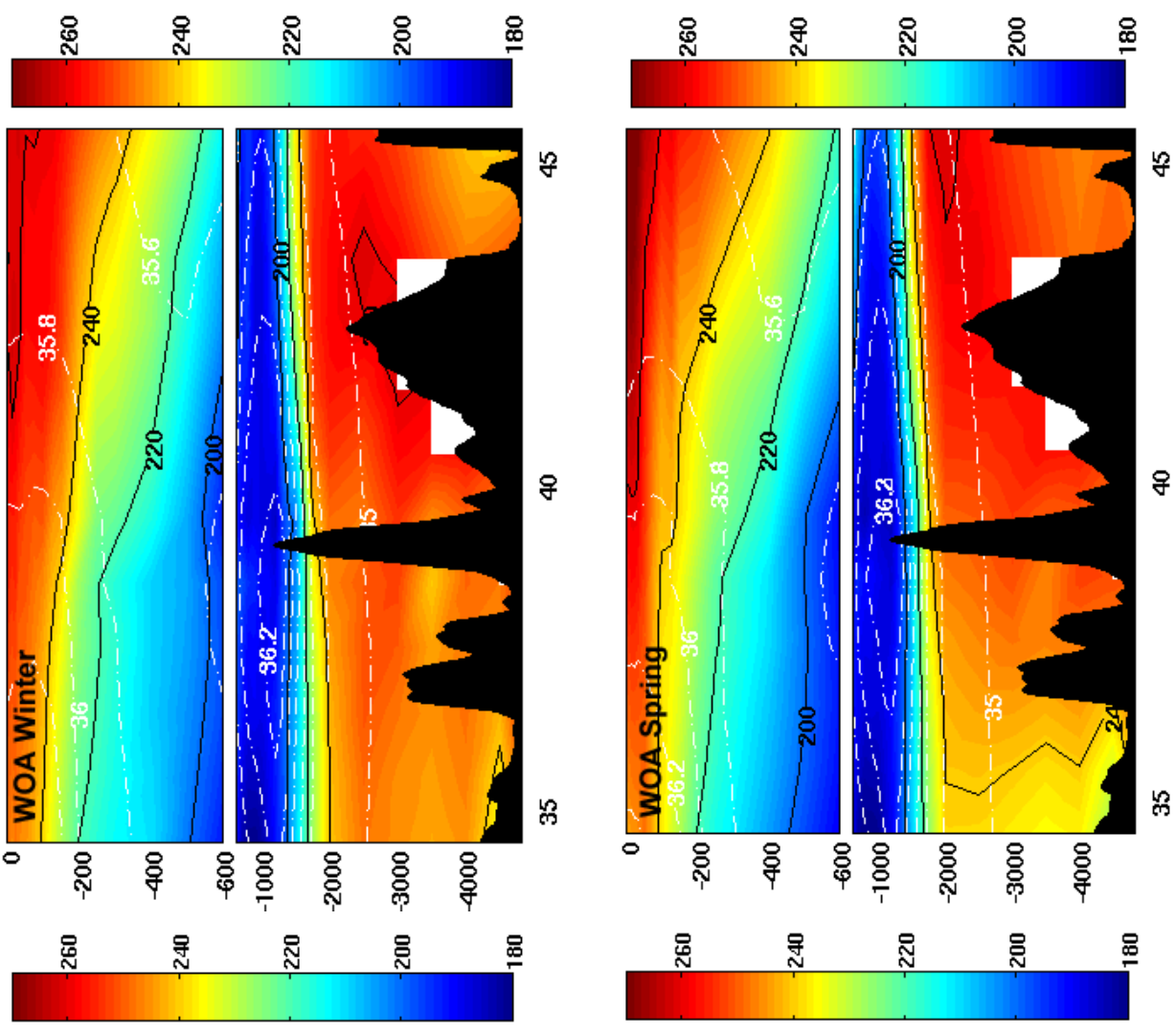

33
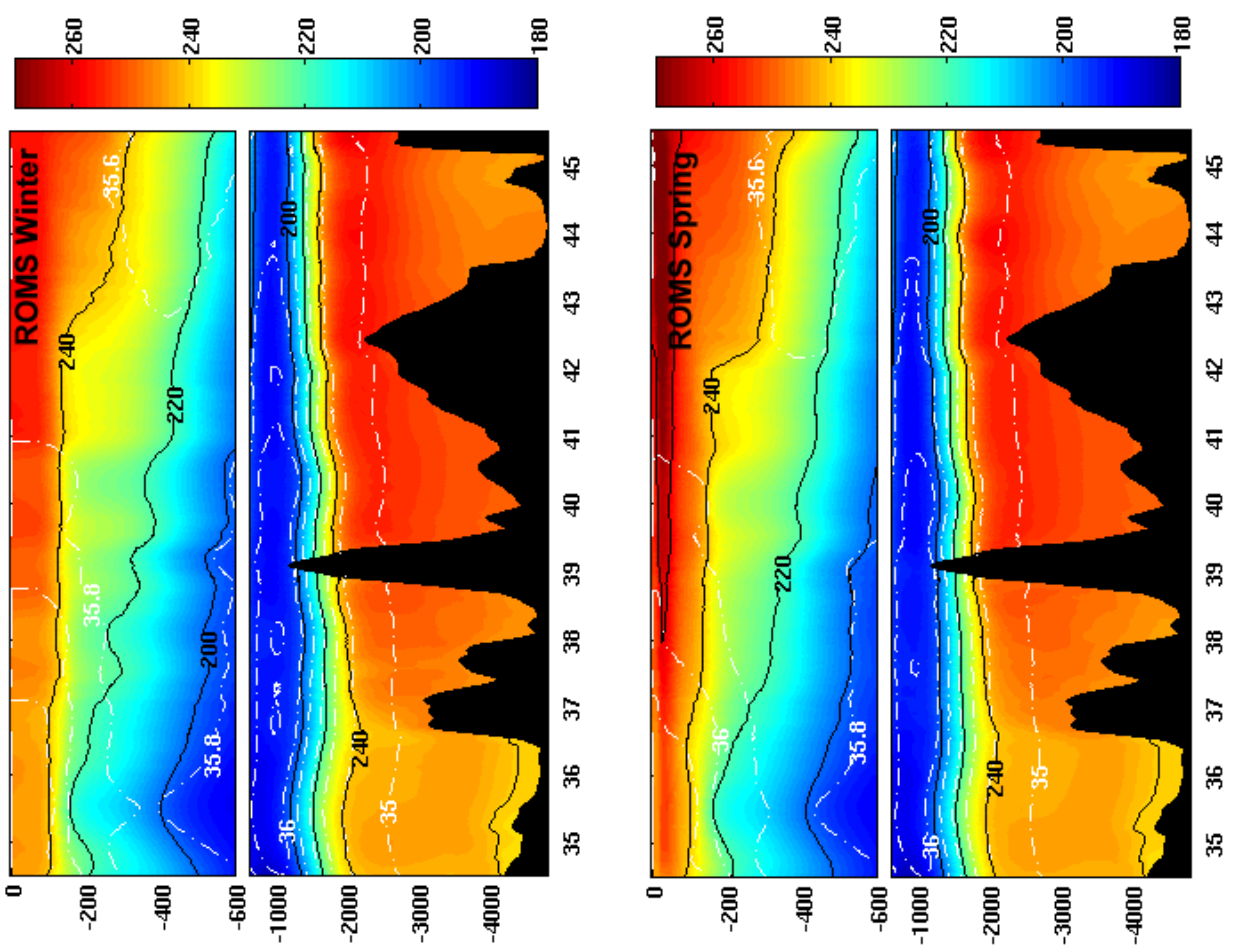

Figure 5: Seasonal mean of dissolved oxyggen $\left(\mathrm{mmol} \mathrm{O}_{2} \mathrm{~m}^{-3}\right)$ in the water column along a meridional section at $10.5^{\circ} \mathrm{W}$ from model results (ROMS) and from climatological data (WOA 2009) (solid line). Modelled values correspond to six years averages of surface oxygen. WOA values are based on observations from 1921 to 2008. Also shown salinity (psu) (white dashed line). 


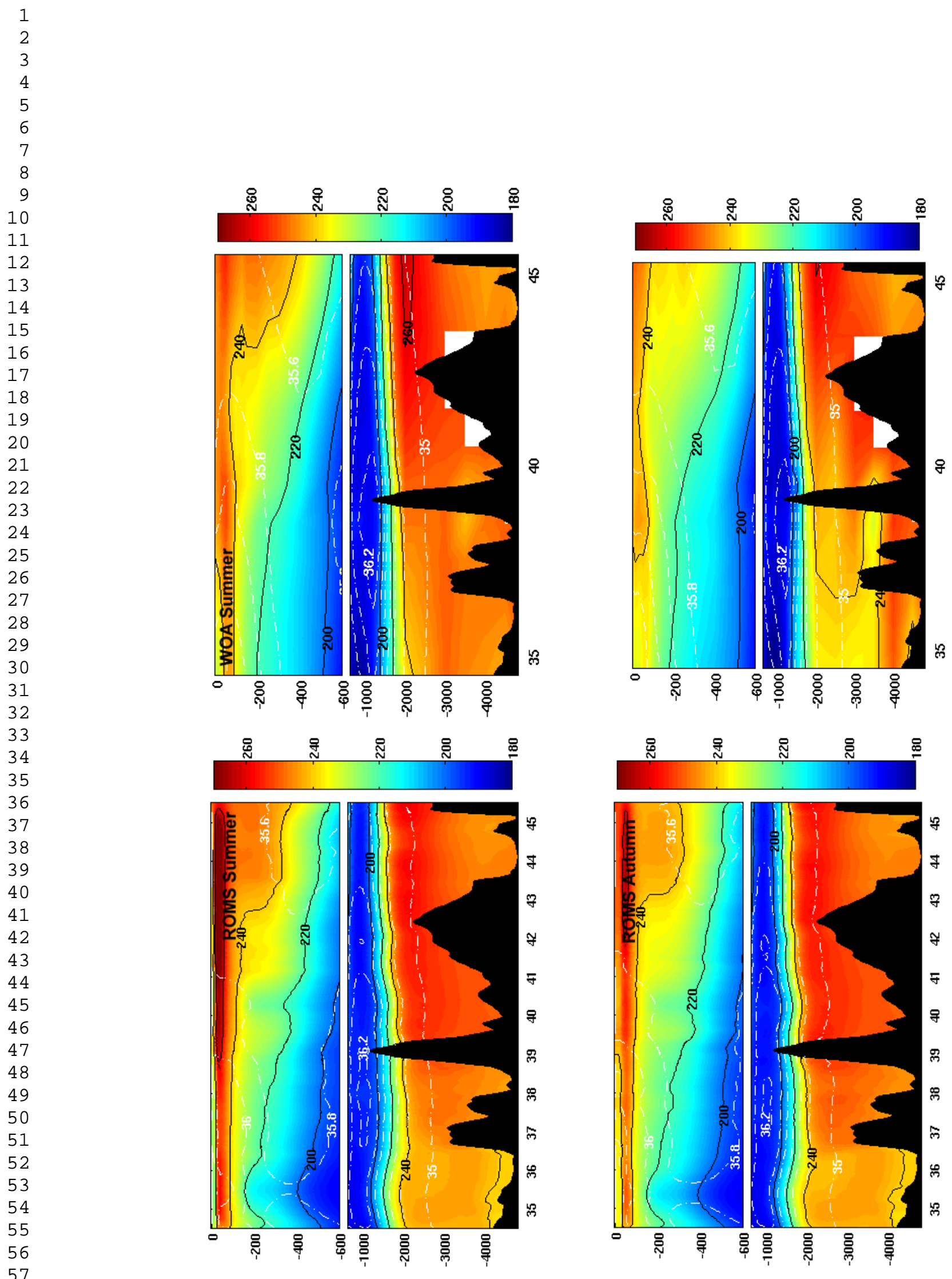

Figure 5:3fontinued. 


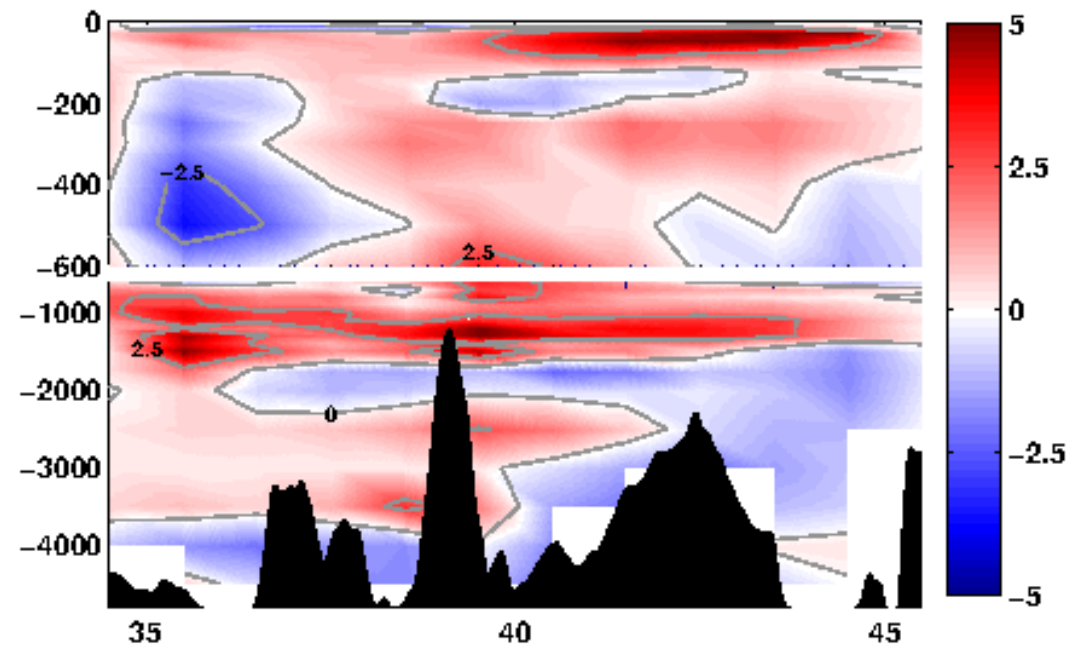

Figure 6: Pbias (\%) of annual mean of dissolved oxygen in the water column along a meridional section at $10.5^{\circ} \mathrm{W}$ from ROMS model results vs. climatological data (WOA 2009). Lines of $-2.5 \%,+2.5 \%$ and $0 \%$ Pbias are shown. 

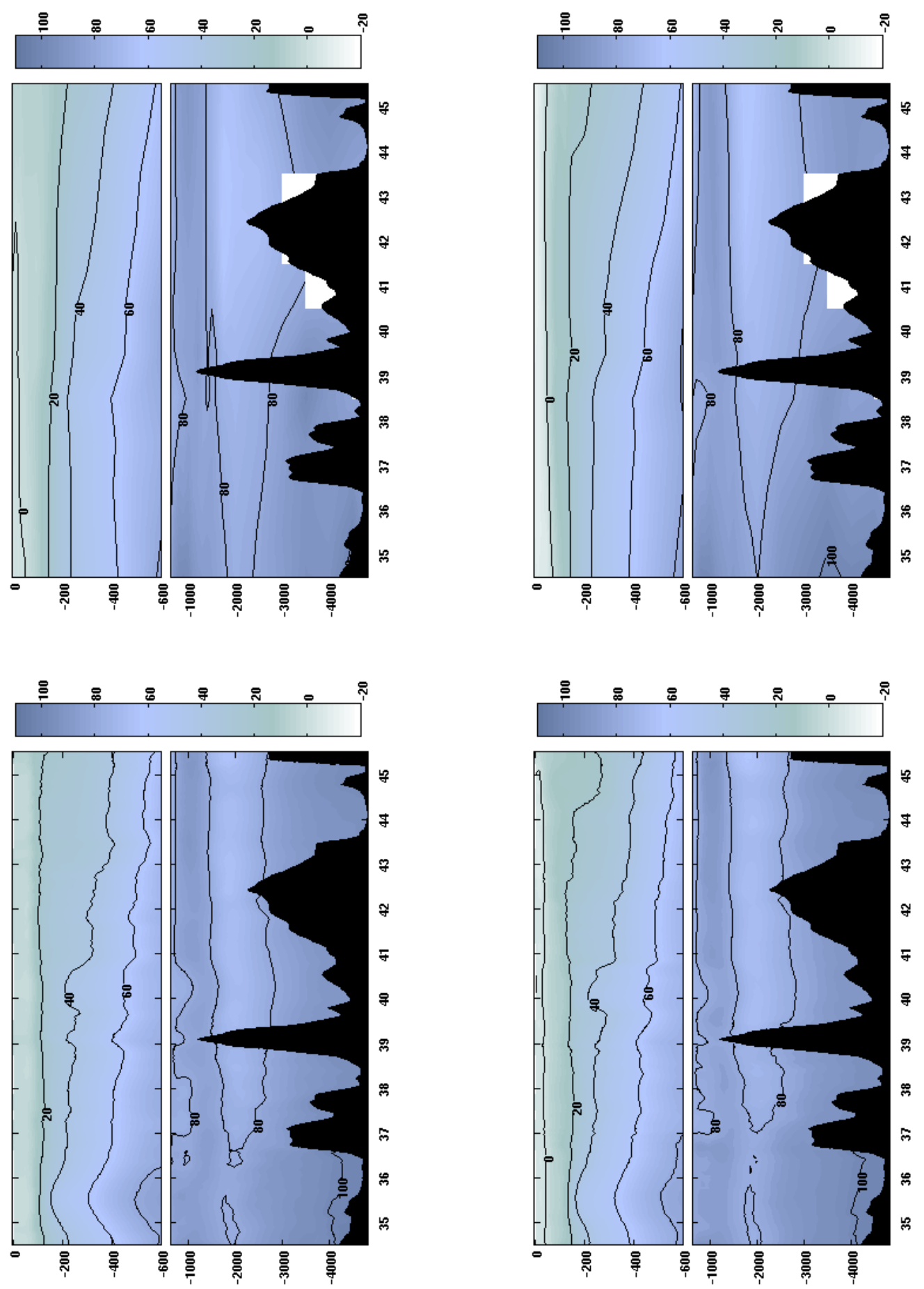

Figure 7: Seasonal mean of apparent 3yygen utilization $(A O U)\left(\mathrm{mmol} \mathrm{O}_{2} \mathrm{~m}^{-3}\right)$ in the water column along a meridional section at $10.5^{\circ} \mathrm{W}$ calculated from model results (ROMS) and from climatological data (WOA 2009). Modelled values correspond to six years averages of surface oxygen. WOA values are based on observations from 1921 to 2008 . 

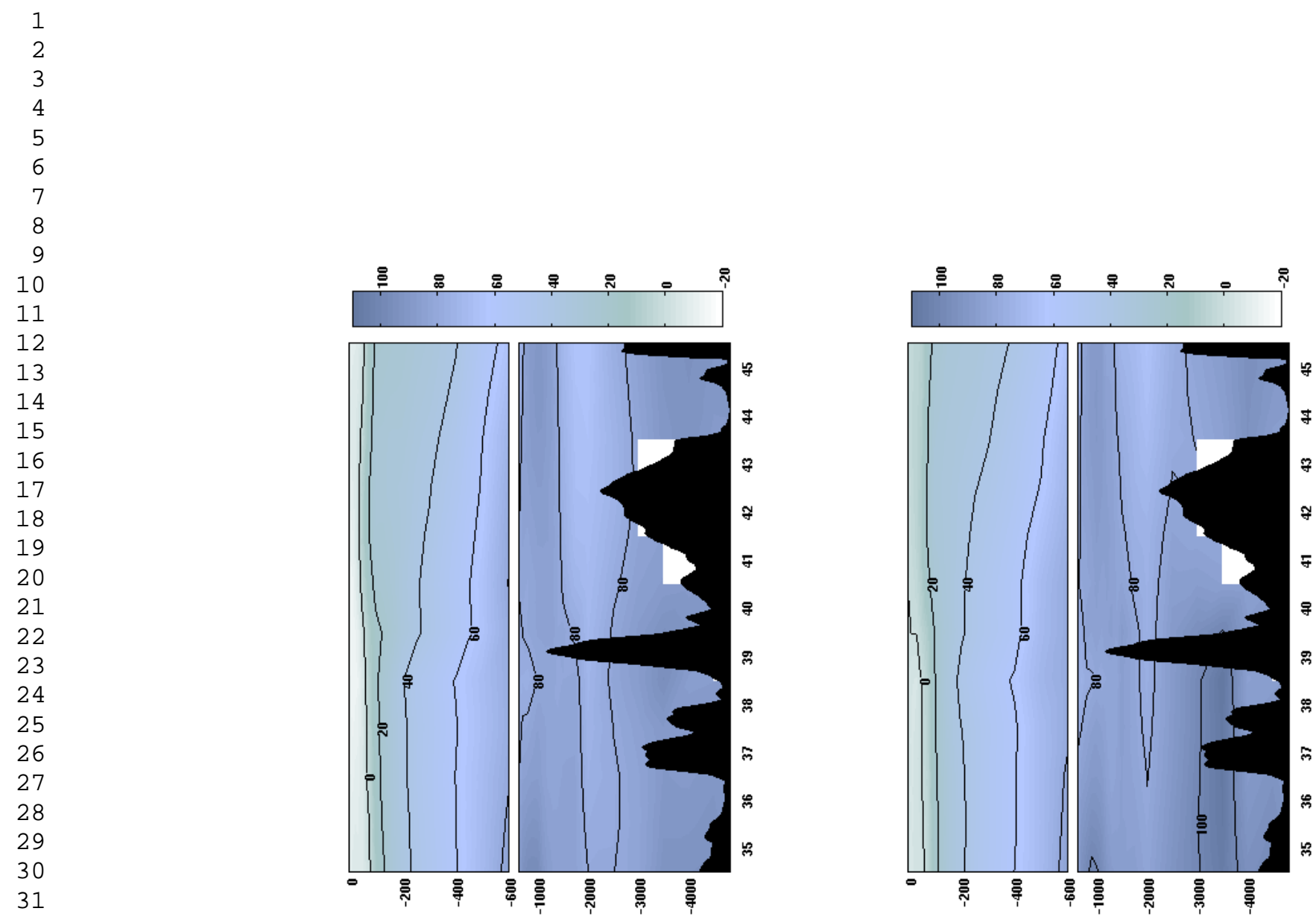

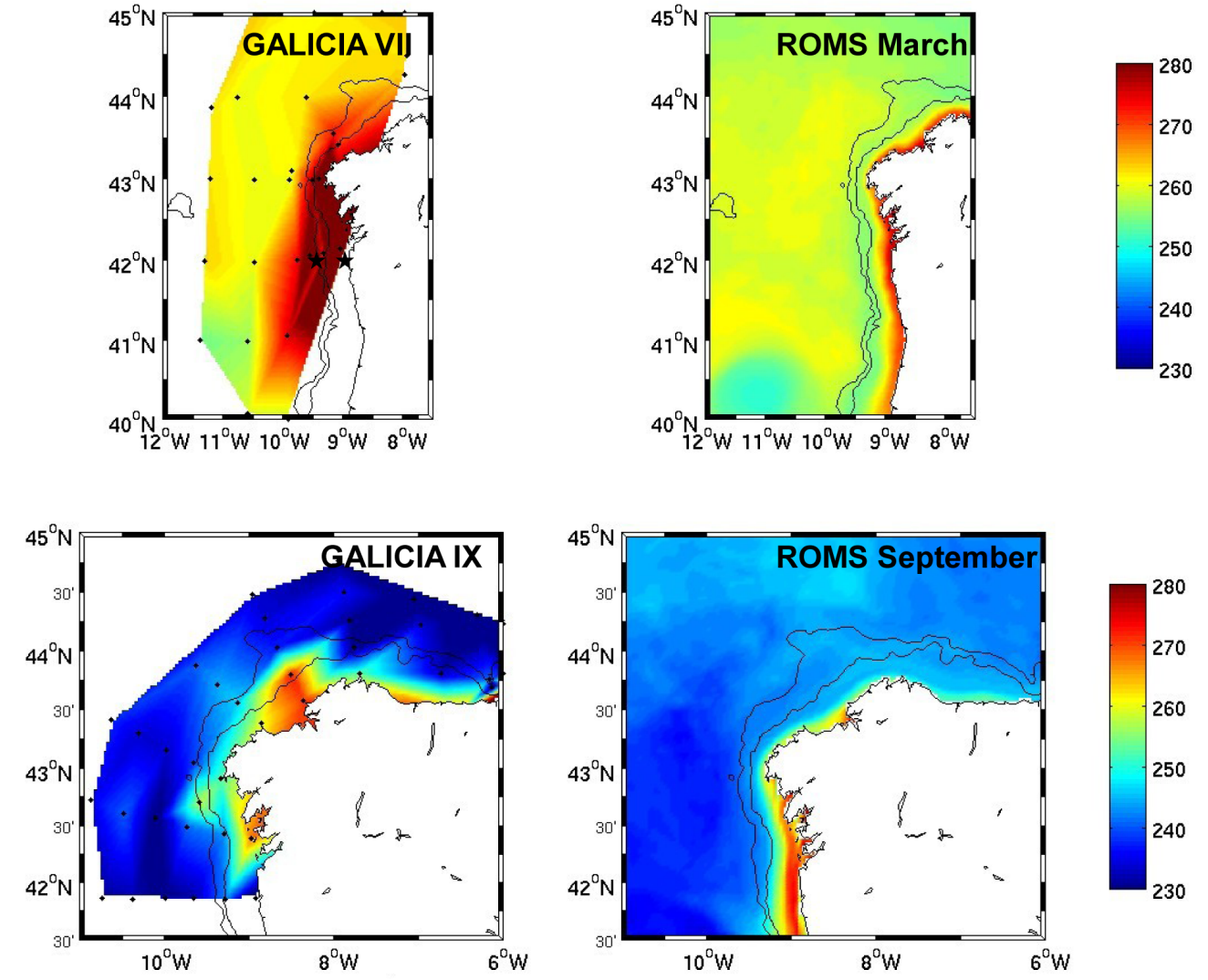

Figure 8: Sea surface dissolved $\mathrm{O}_{2}\left(\mathrm{mmol} \mathrm{O}_{2} \mathrm{~m}^{-3}\right)$ in the Galician shelf during the cruises GALICIA VII (February-March 1984) and GALICIA IX (September 1986) (sampling stations shown) and the corresponding ROMS climatological mean for March and September. Stars indicate the position of the two weekly sampling stations for the period May 2001-April 2002. Isobaths of $200 \mathrm{~m}$ and $1000 \mathrm{~m}$ are represented. 
Figure 9: Time evolution of observed (upper panels) and modelled (lower panels) dissolved $\mathrm{O}_{2}\left(\mathrm{mmol} \mathrm{O}_{2} \mathrm{~m}^{-3}\right)(\mathrm{a}, \mathrm{d})$, temperature $\left({ }^{\circ} \mathrm{C}\right)(\mathrm{b}, \mathrm{e})$ and salinity $(\mathrm{psu})(\mathrm{c}, \mathrm{f})$ in the water column at station $5\left(42^{\circ} \mathrm{N}, 9.5^{\circ} \mathrm{W}\right)$ (slope) for the sampling period May 2001-April 2002. Dots represent sampling depths. 
Figure 10: Time evolution of observed (upper panels) and modelled (lower panels) dissolved $\mathrm{O}_{2}\left(\mathrm{mmol} \mathrm{O}_{2} \mathrm{~m}^{-3}\right)(\mathrm{a}, \mathrm{d})$, temperature $\left({ }^{\circ} \mathrm{C}\right)(\mathrm{b}, \mathrm{e})$ and salinity $(\mathrm{psu})(\mathrm{c}, \mathrm{f})$ in the water column at station $3\left(42^{\circ} \mathrm{N}, 9.16^{\circ} \mathrm{W}\right)$ (shelf) for the sampling period May 2001-April 2002. Dots represent sampling depths. 
Figure 11: Snapshot of the northwestern part of the domain on the 30th January 2002 under strong influence of the IPC: modelled sea surface dissolved $\mathrm{O}_{2}$ $\left(\mathrm{mmol} \mathrm{O}_{2} \mathrm{~m}^{-3}\right)$ and modelled surface velocities field (arrows) $\left(\mathrm{m} \mathrm{s}^{-1}\right)$ showing a tongue of low oxygen concentration advancing northwards over the slope, and getting oxygen enriched downstream. 
Winter

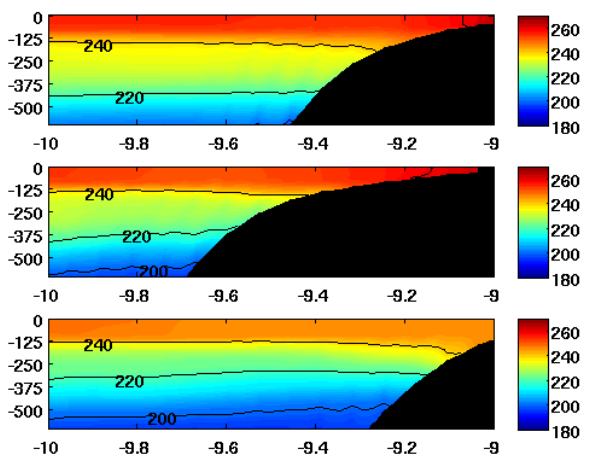

Spring
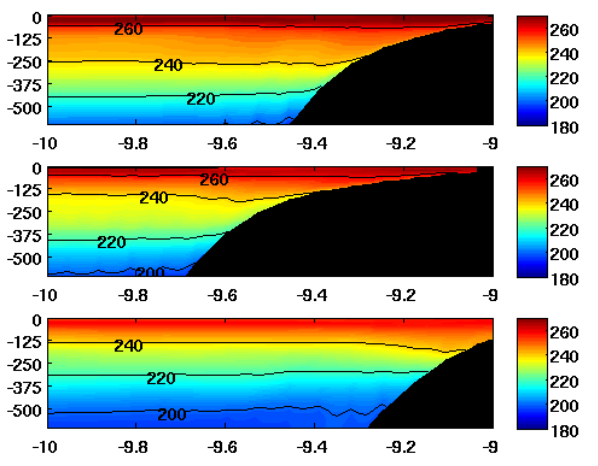

Summer

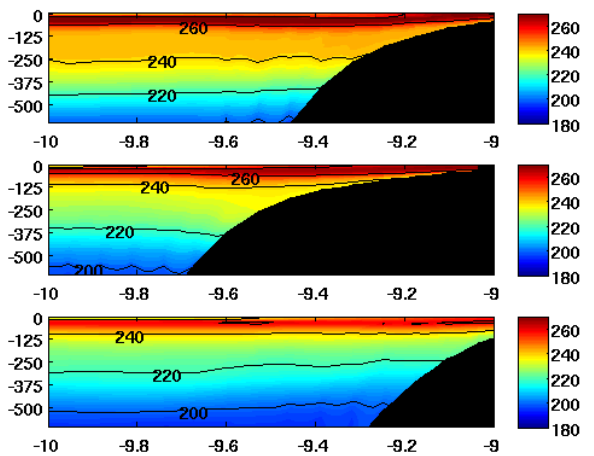

Autumn
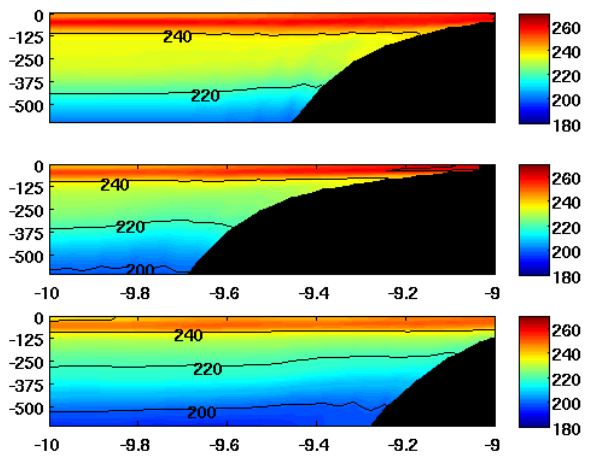

Figure 12: Seasonal means of ROMS dissolved $\mathrm{O}_{2}\left(\mathrm{mmol} \mathrm{O}_{2} \mathrm{~m}^{-3}\right)$ along three cross-shelf sections in the Iberian Atlantic margin at $42^{\circ} \mathrm{N}, 40^{\circ} \mathrm{N}$ and $38^{\circ} \mathrm{N}$ (longitude degrees in the x-axis). 
Winter anomaly
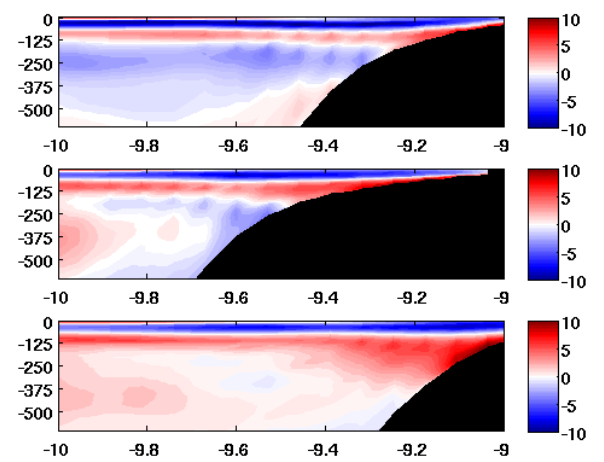

Spring anomaly
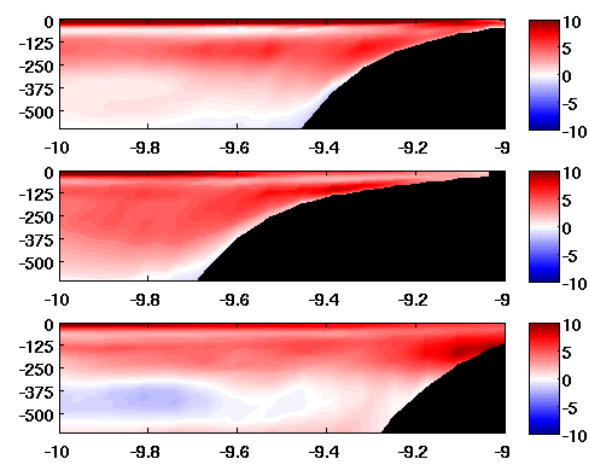

\section{Summer anomaly}
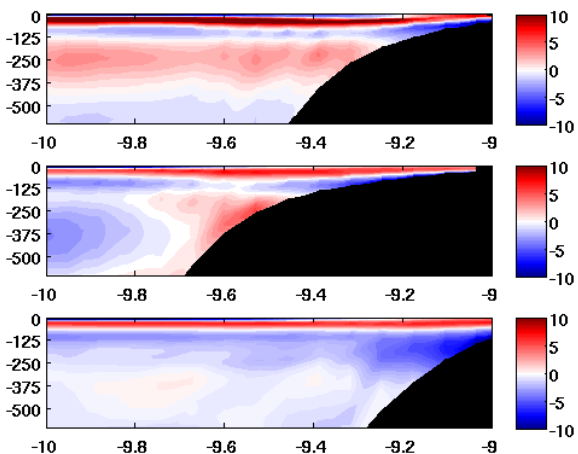

Autumn anomaly
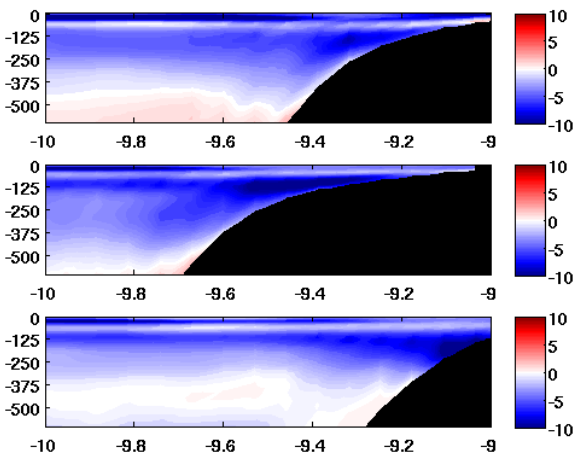

Figure 13: Seasonal ROMS $\mathrm{O}_{2}$ anomalies $\left(\mathrm{mmol} \mathrm{O}_{2} \mathrm{~m}^{-3}\right)$ and nitrate anomalies $\left(\mathrm{mmol} \mathrm{N} \mathrm{m}{ }^{-3}\right.$ ) (see Figure continuation) [anomaly = seasonal mean - annual mean] along three cross-shelf sections in the Iberian Atlantic margin at $42^{\circ} \mathrm{N}, 40^{\circ}$ $\mathrm{N}$ and $38^{\circ} \mathrm{N}$ (longitude degrees in the $\mathrm{x}$-axis). 
Winter anomaly

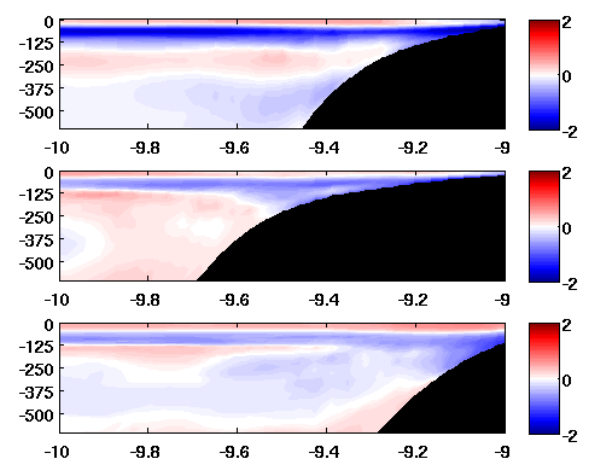

Spring anomaly
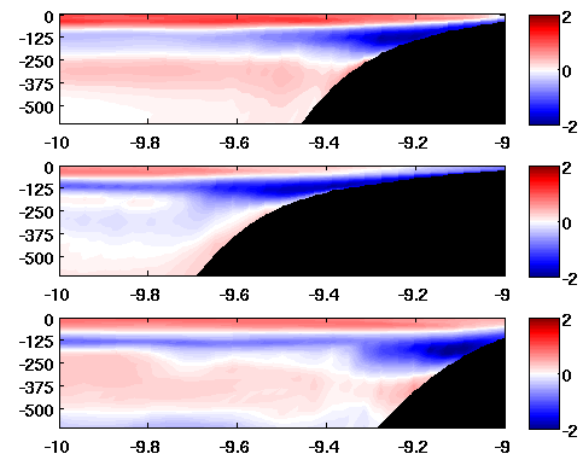

Summer anomaly
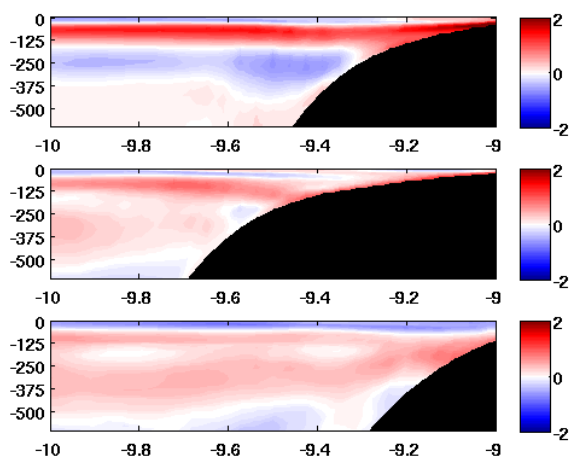

Autumn anomaly
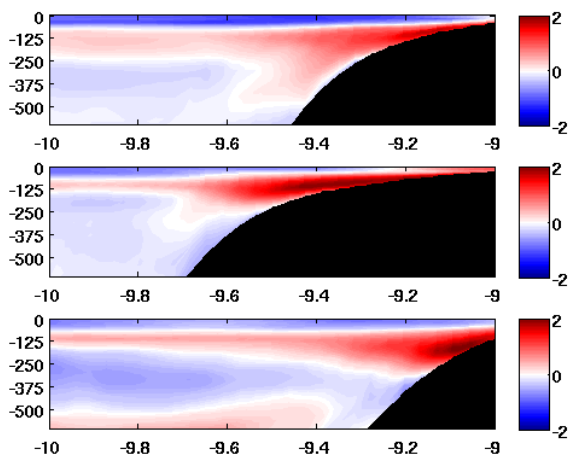

Figure 13: Continued. 
i i. '

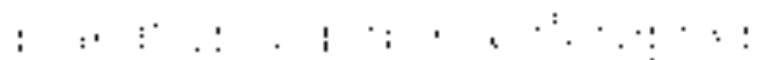

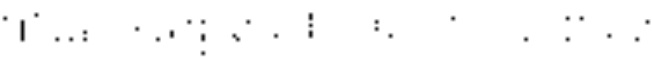

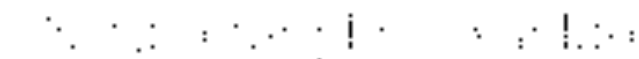

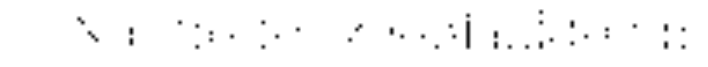

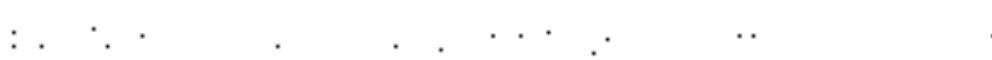

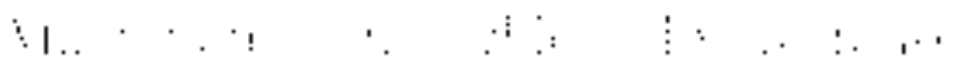

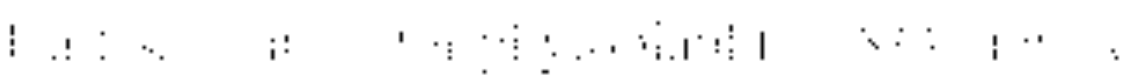

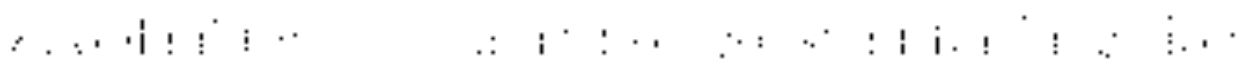

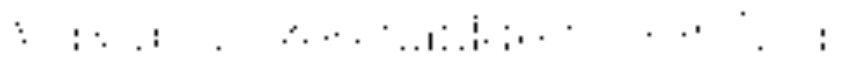

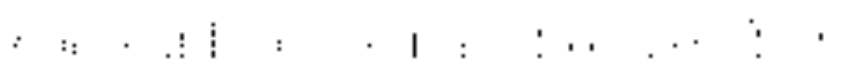

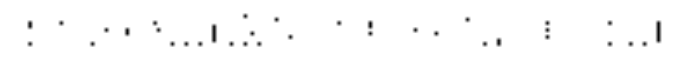

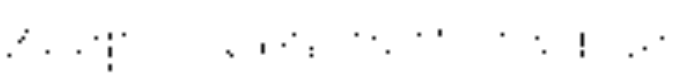

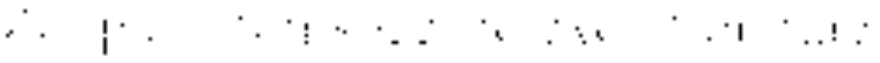

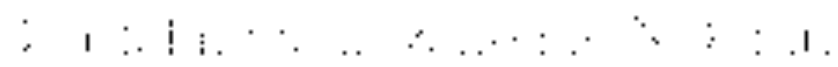

$$
\begin{aligned}
& \text { • }
\end{aligned}
$$

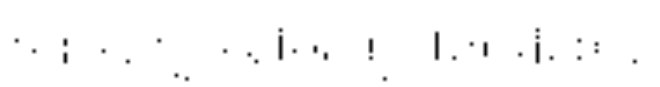

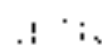

; !

$\therefore \quad \vdots$

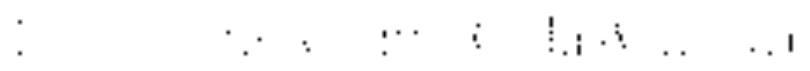

.. . . .

,. .

..

$1,1:$

$$
\text { : } .::^{\circ} \cdot
$$$$
\text { , . : : }: \text { : }
$$

.

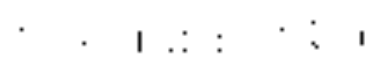

:. $\cdot \quad$ :

- $\mathbf{i}$

$: 1 .:$

i i

11

,

$: 1$

, $:^{-}$

: :

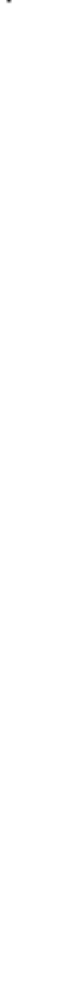




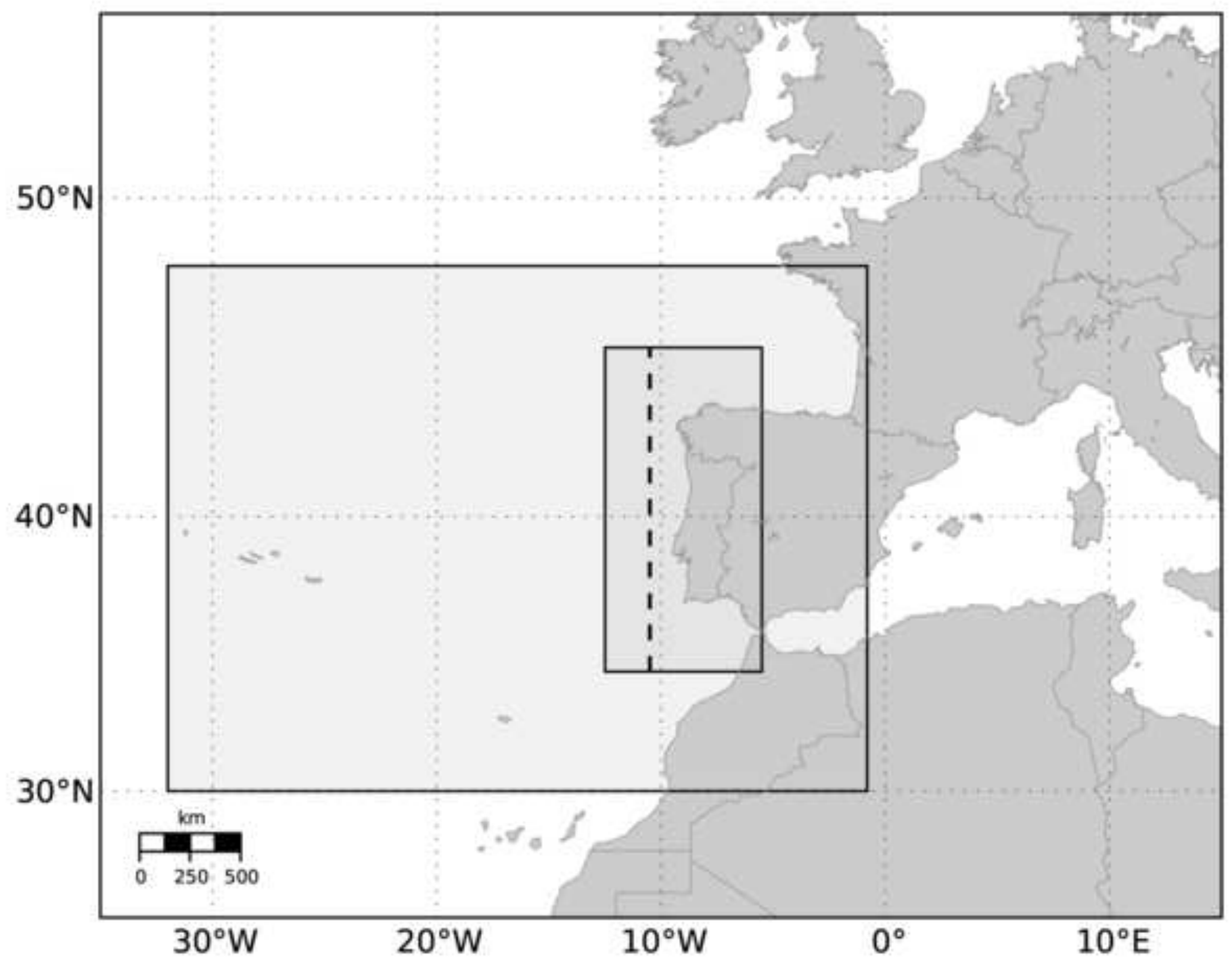




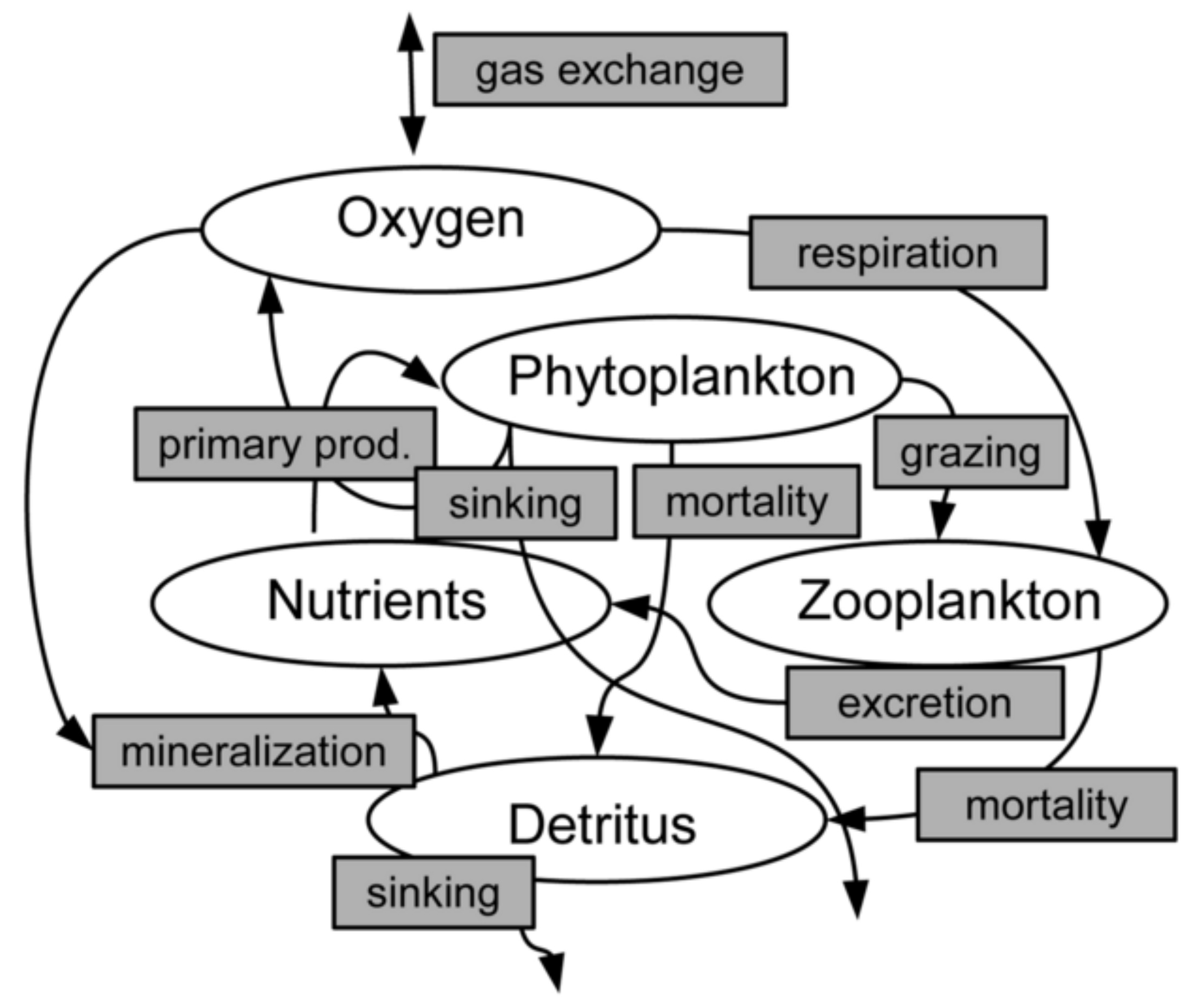




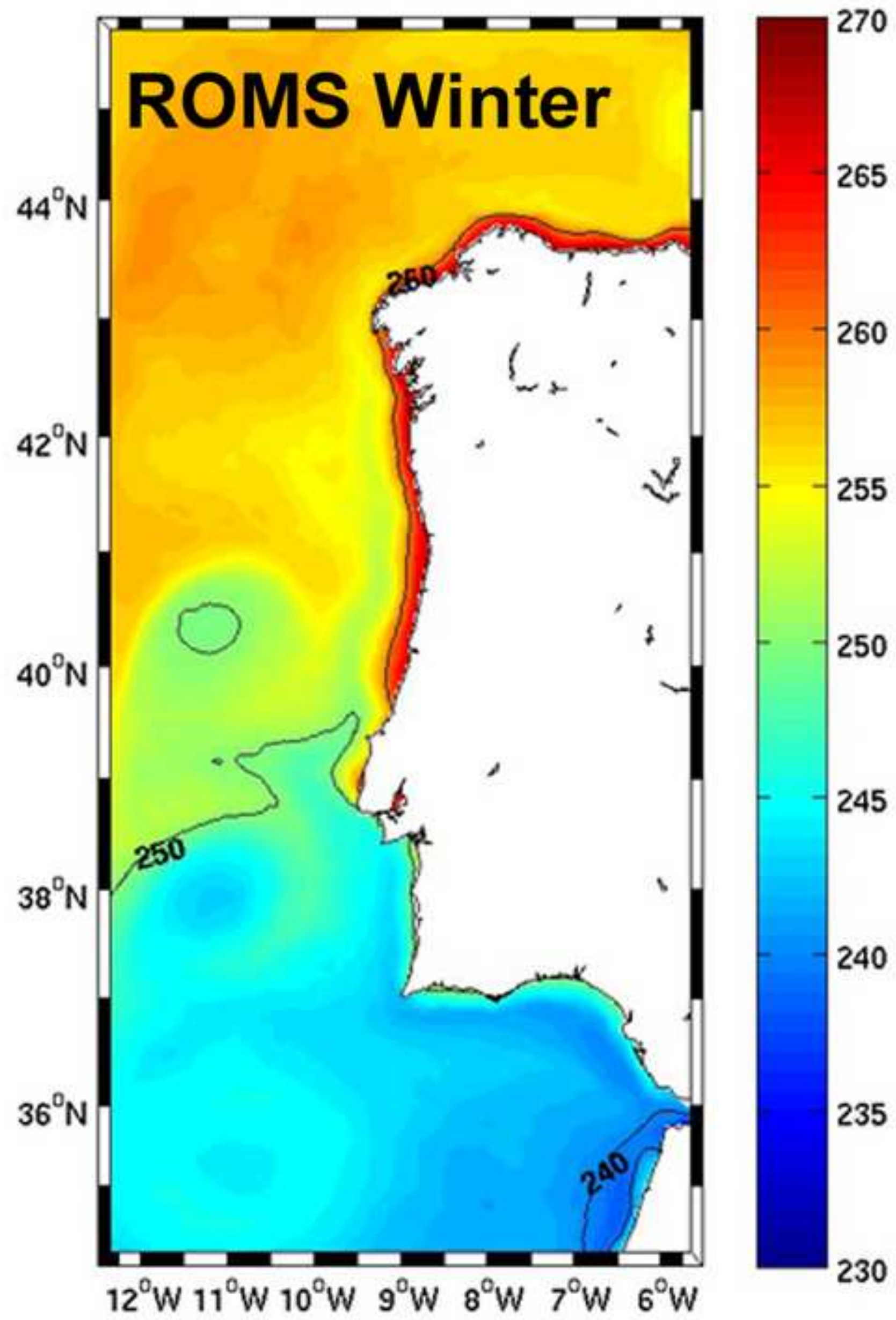


Click here to download high resolution image

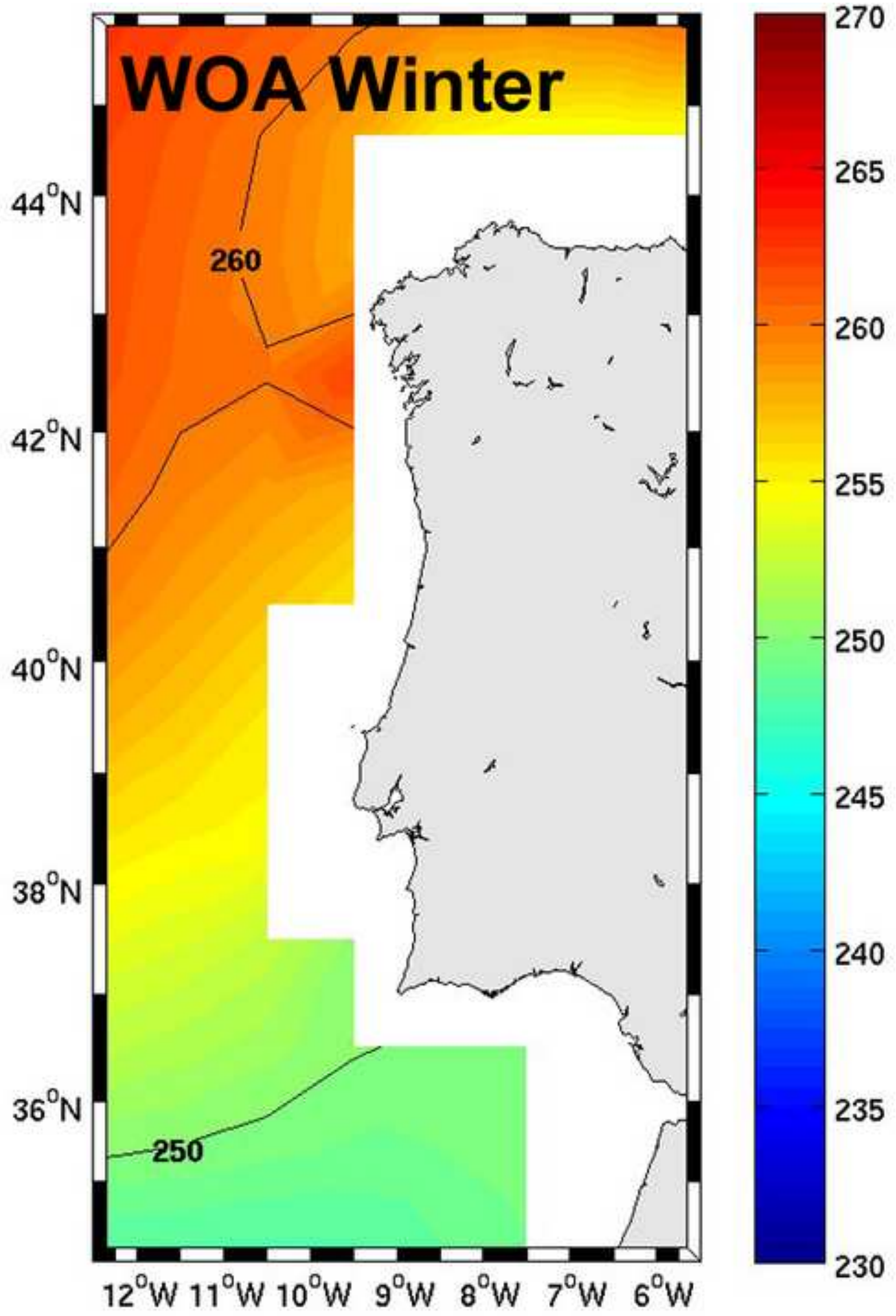




\section{Figure}

Click here to download high resolution image

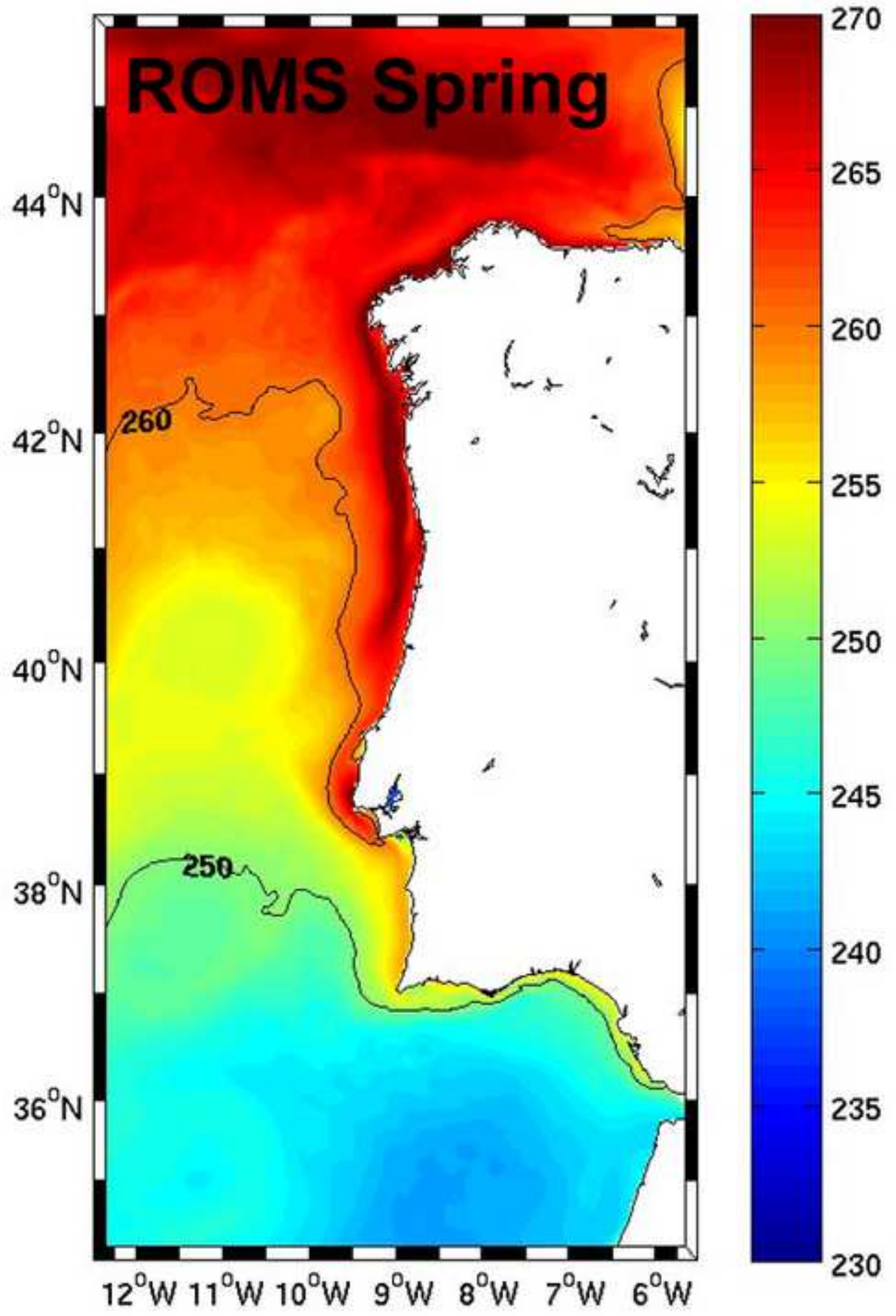


Click here to download high resolution image

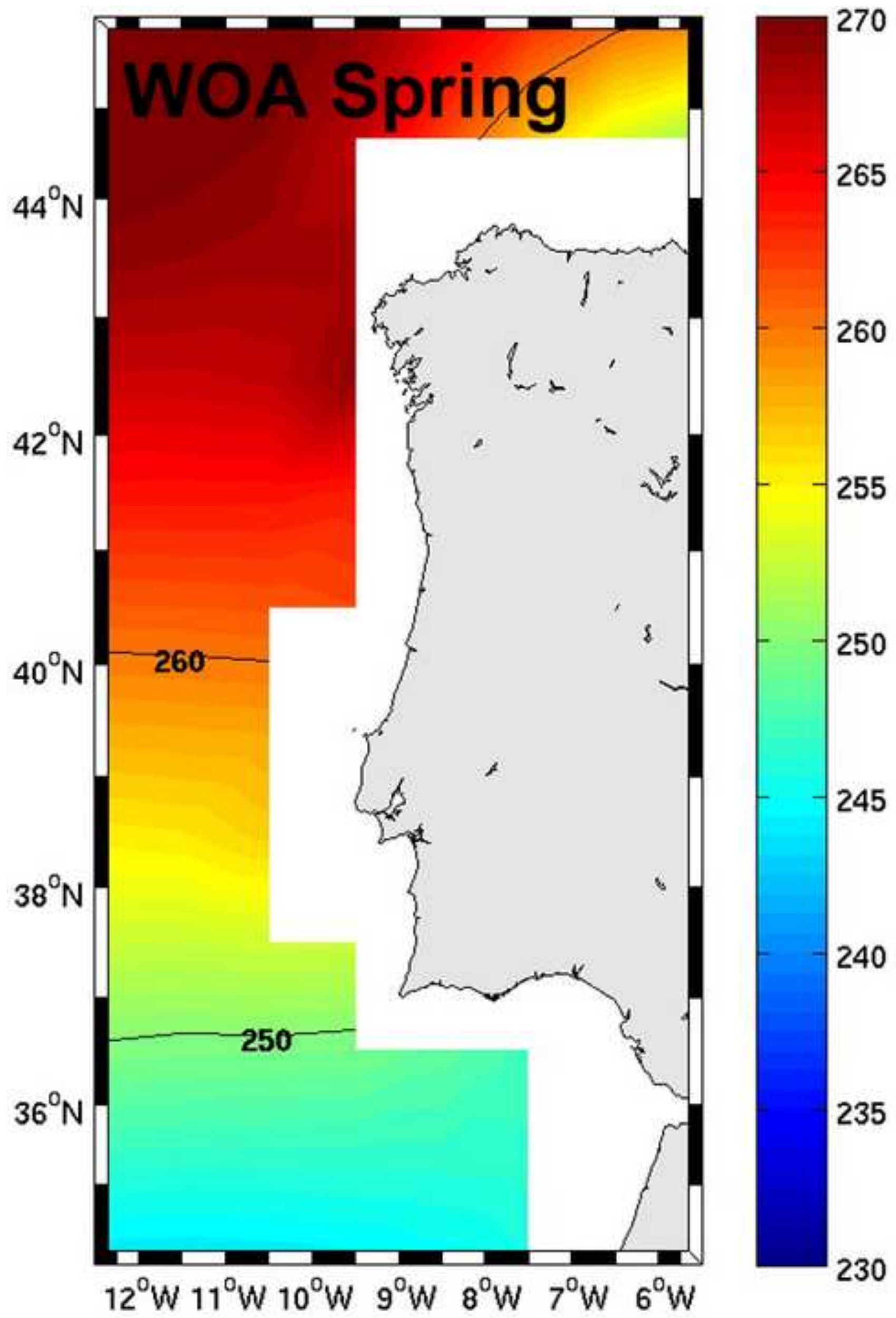




\section{Figure}

Click here to download high resolution image

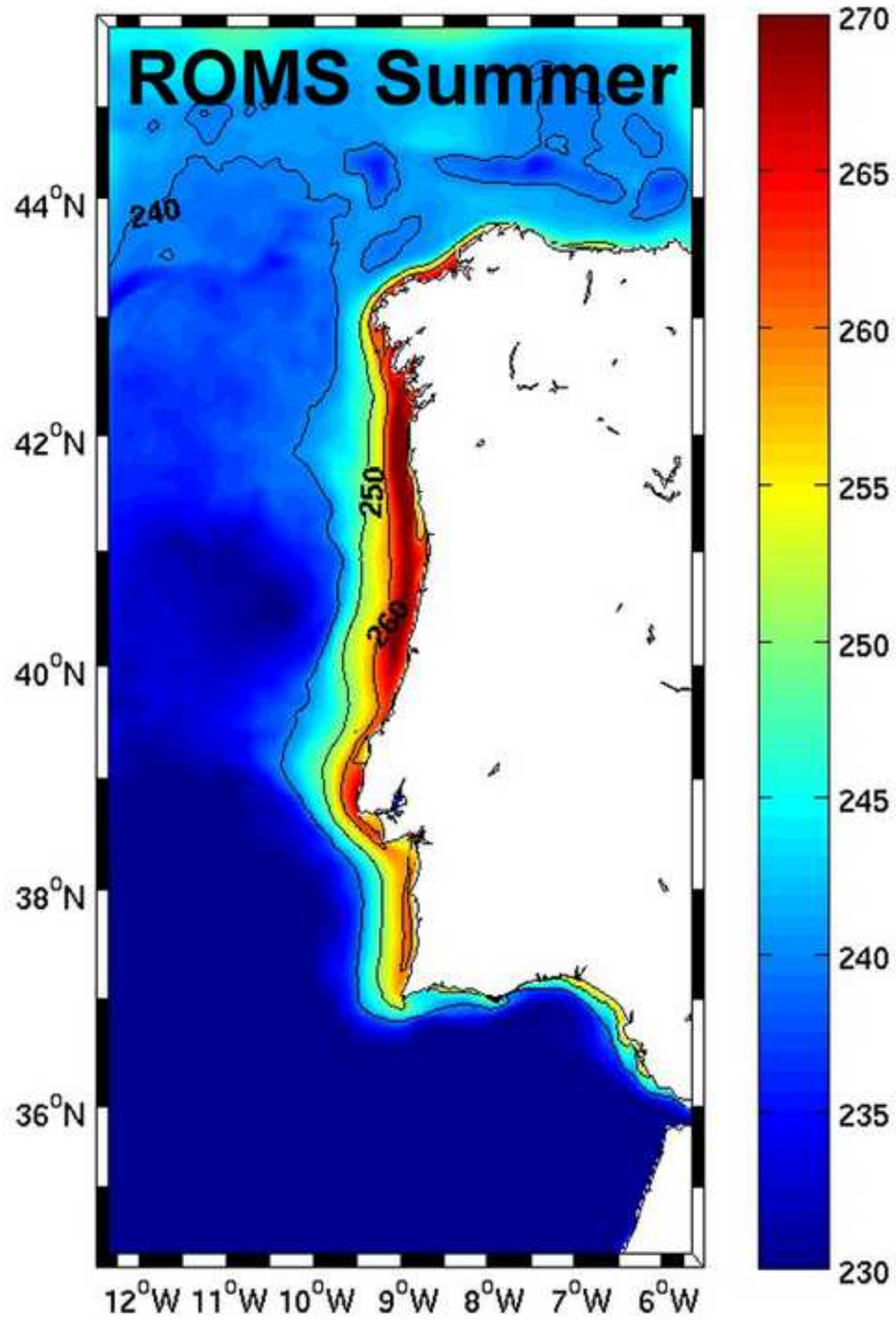


Click here to download high resolution image

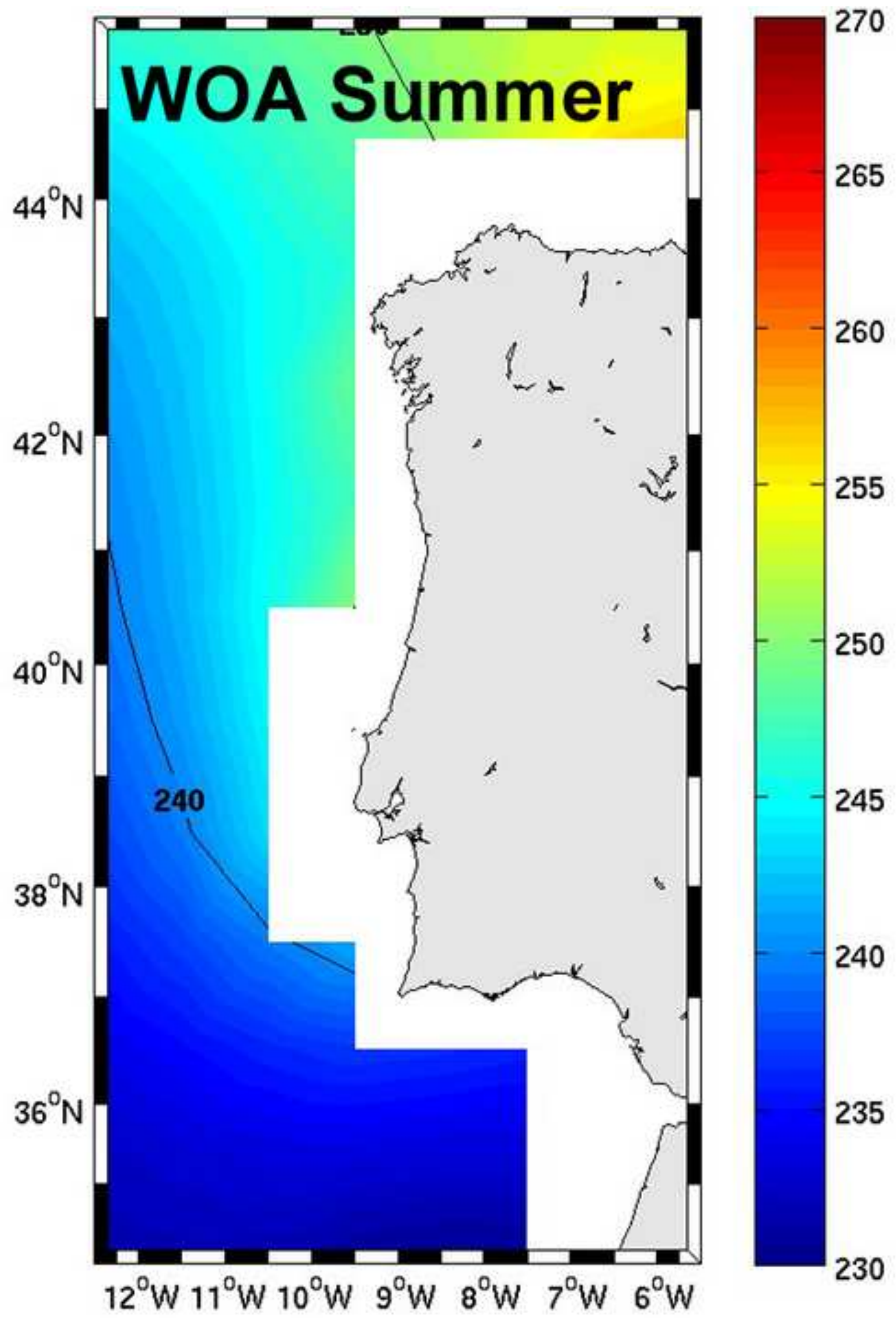




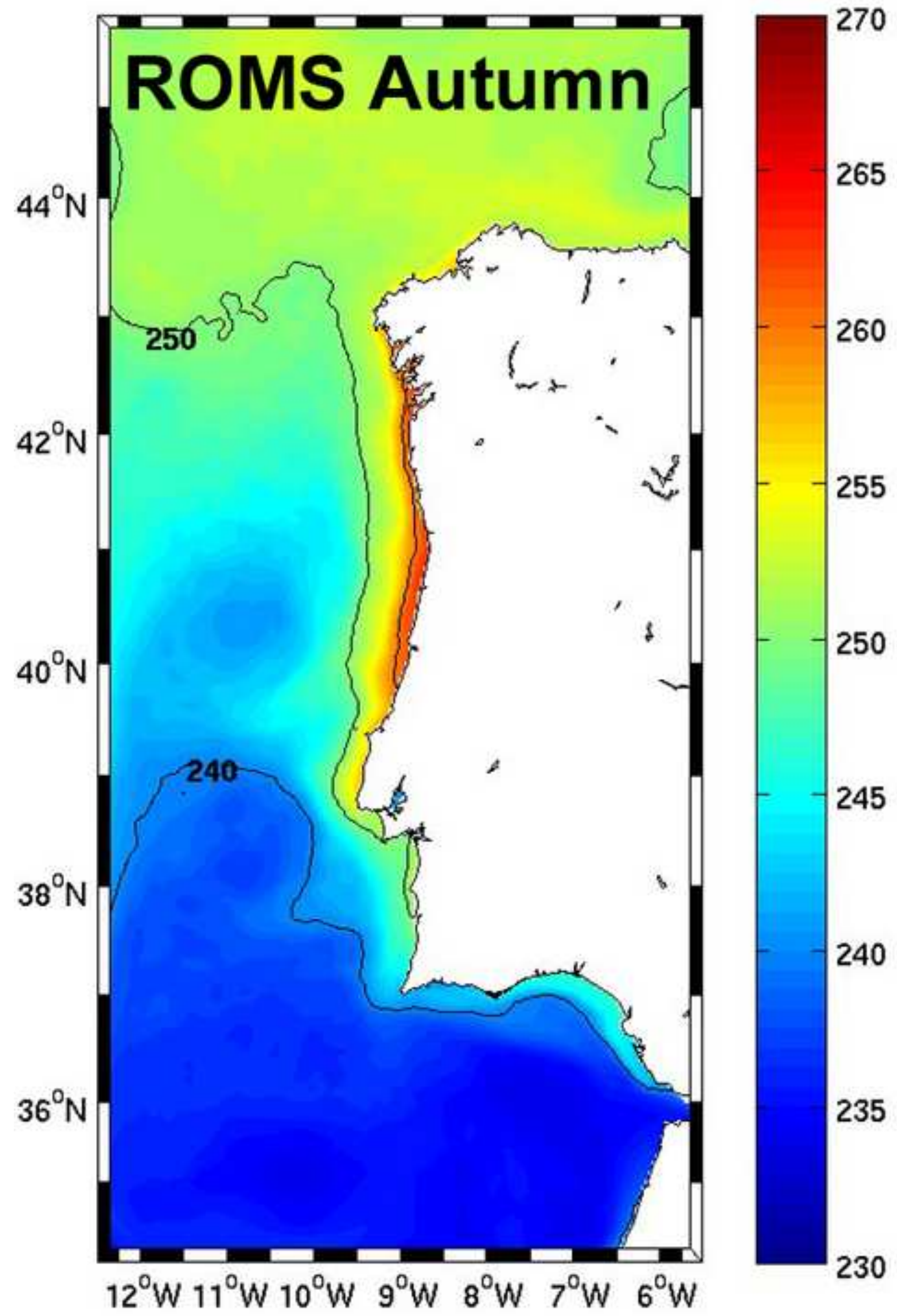


Click here to download high resolution image

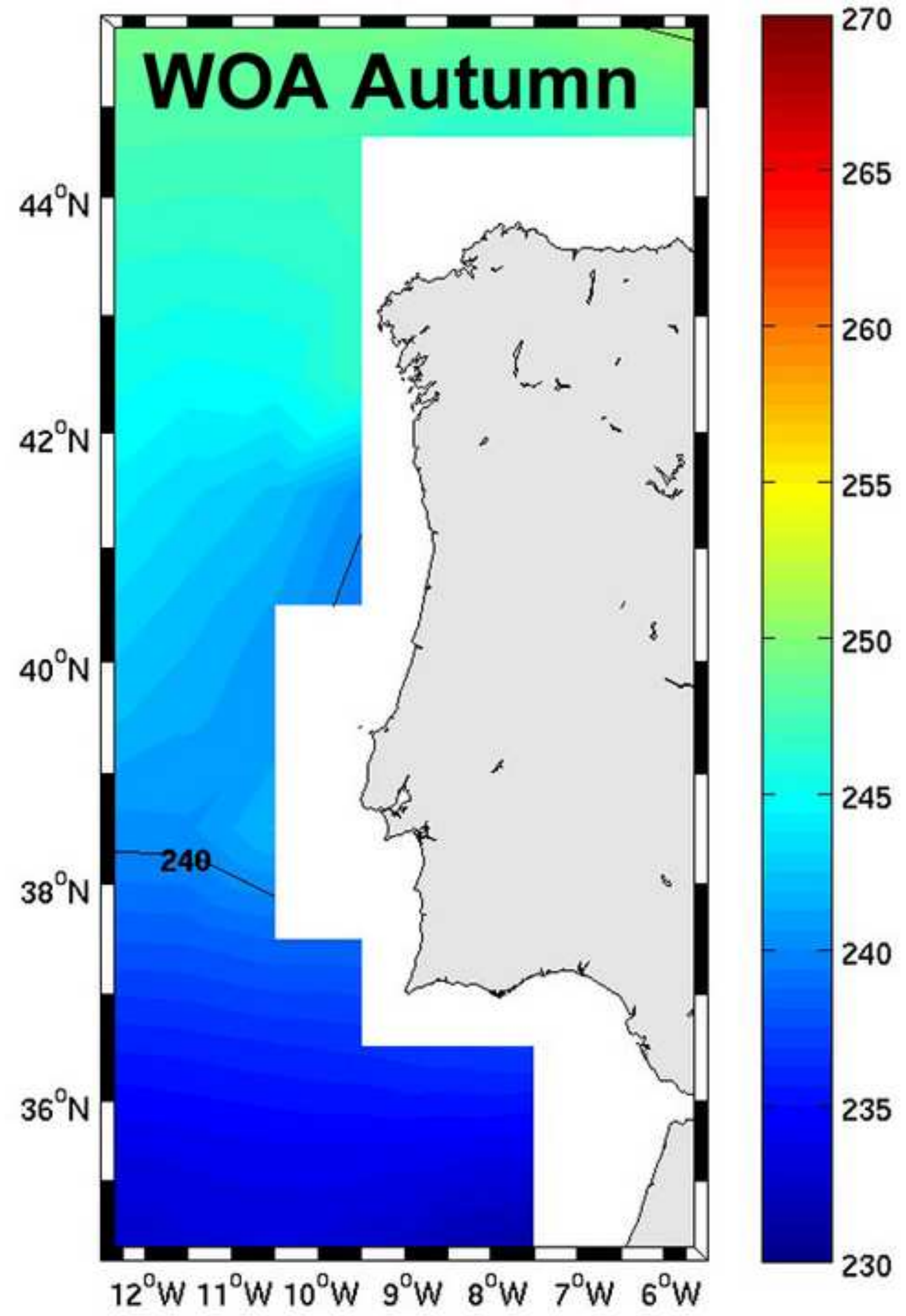



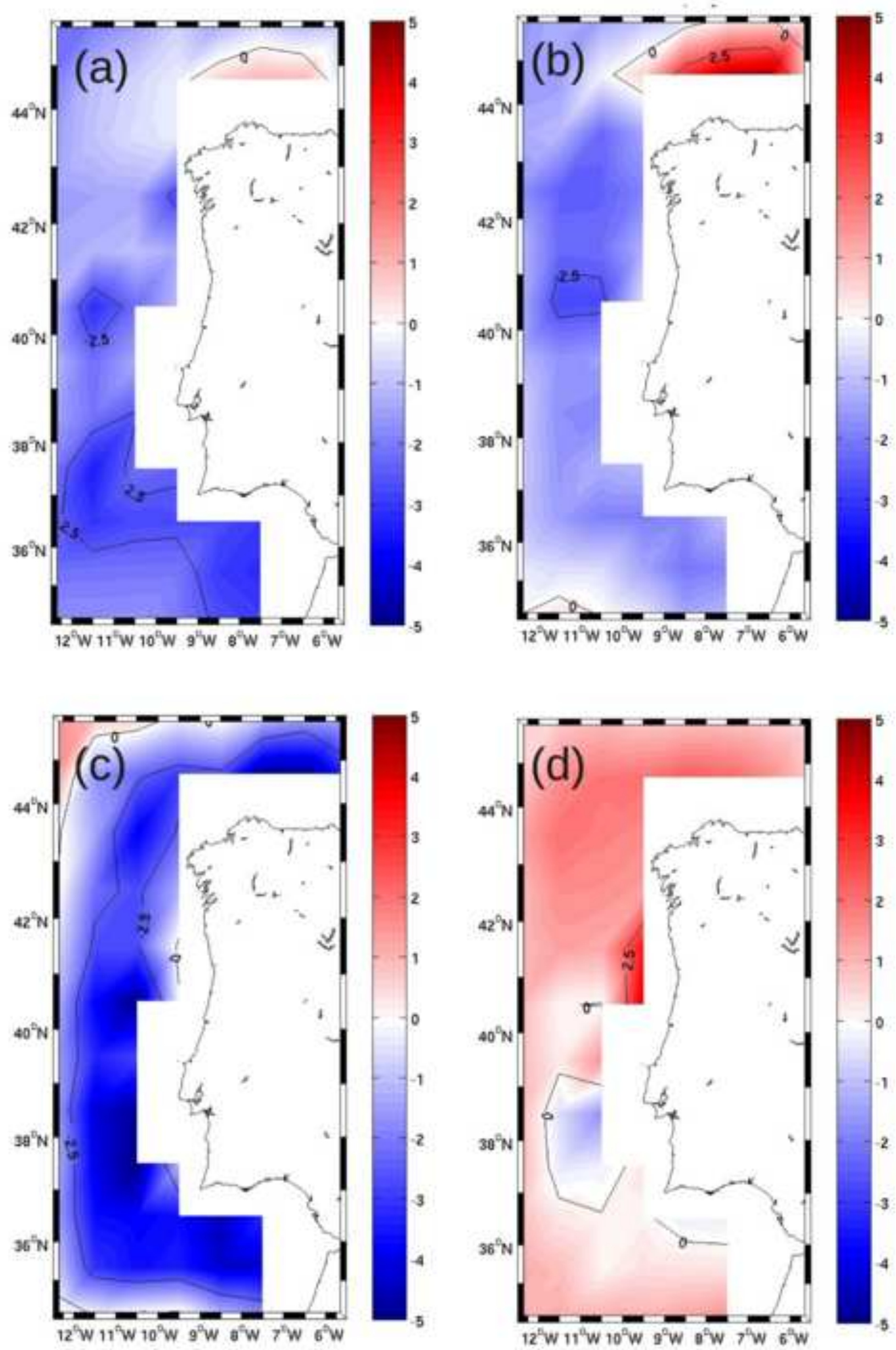


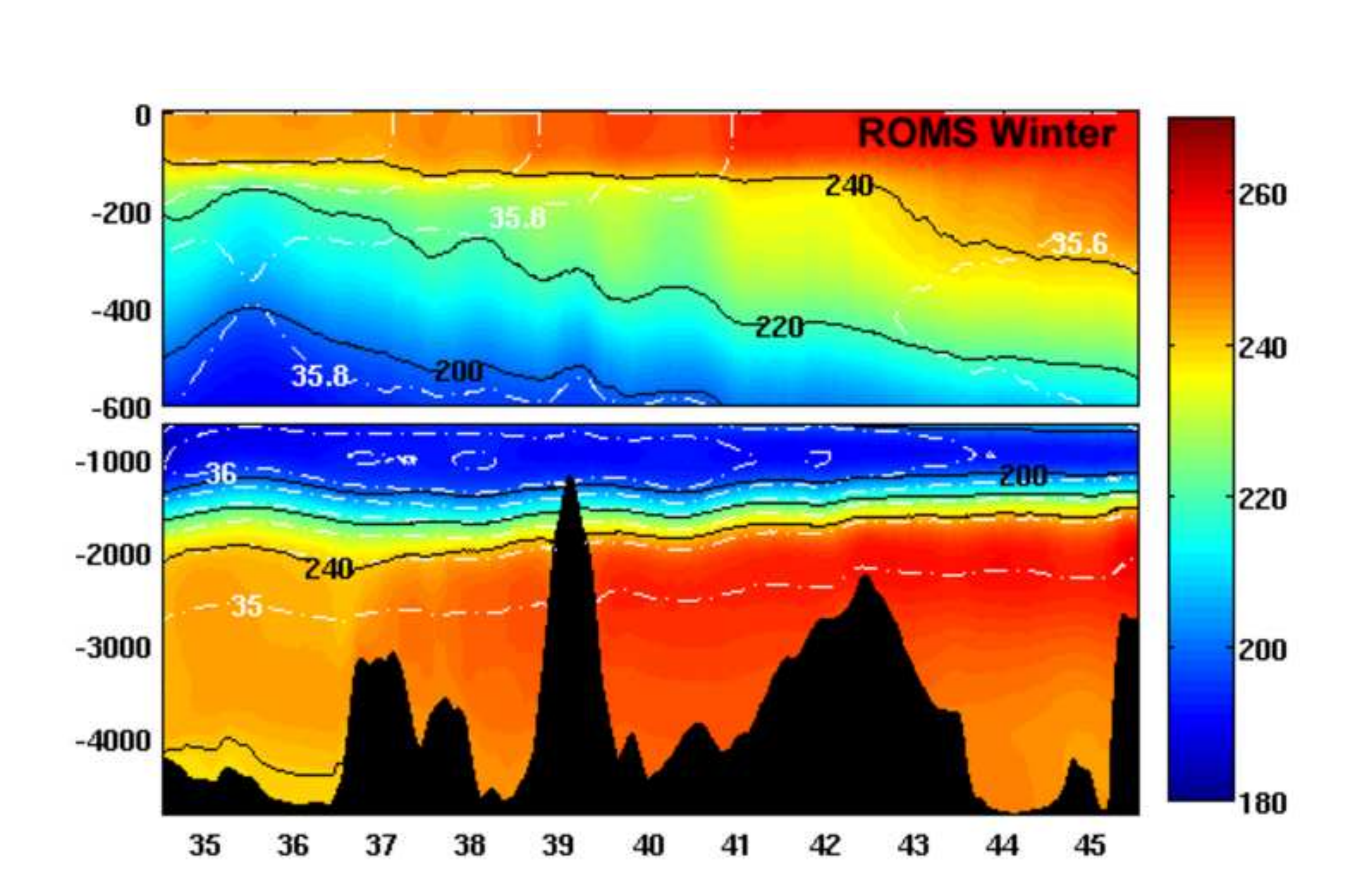

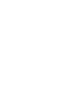

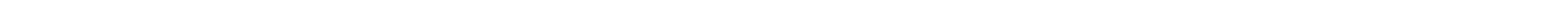$$
\text { . }
$$ 


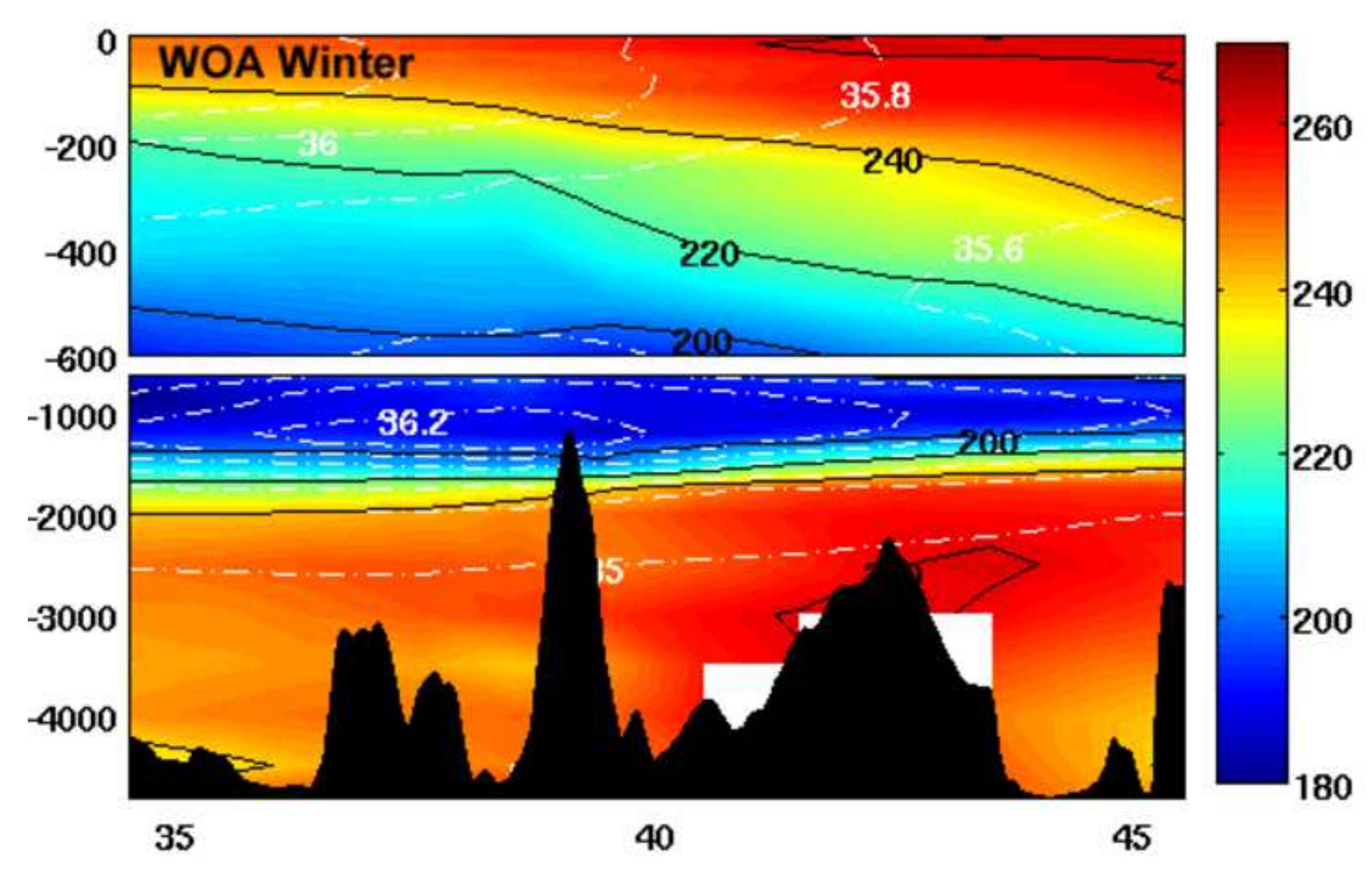

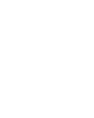

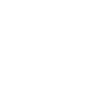



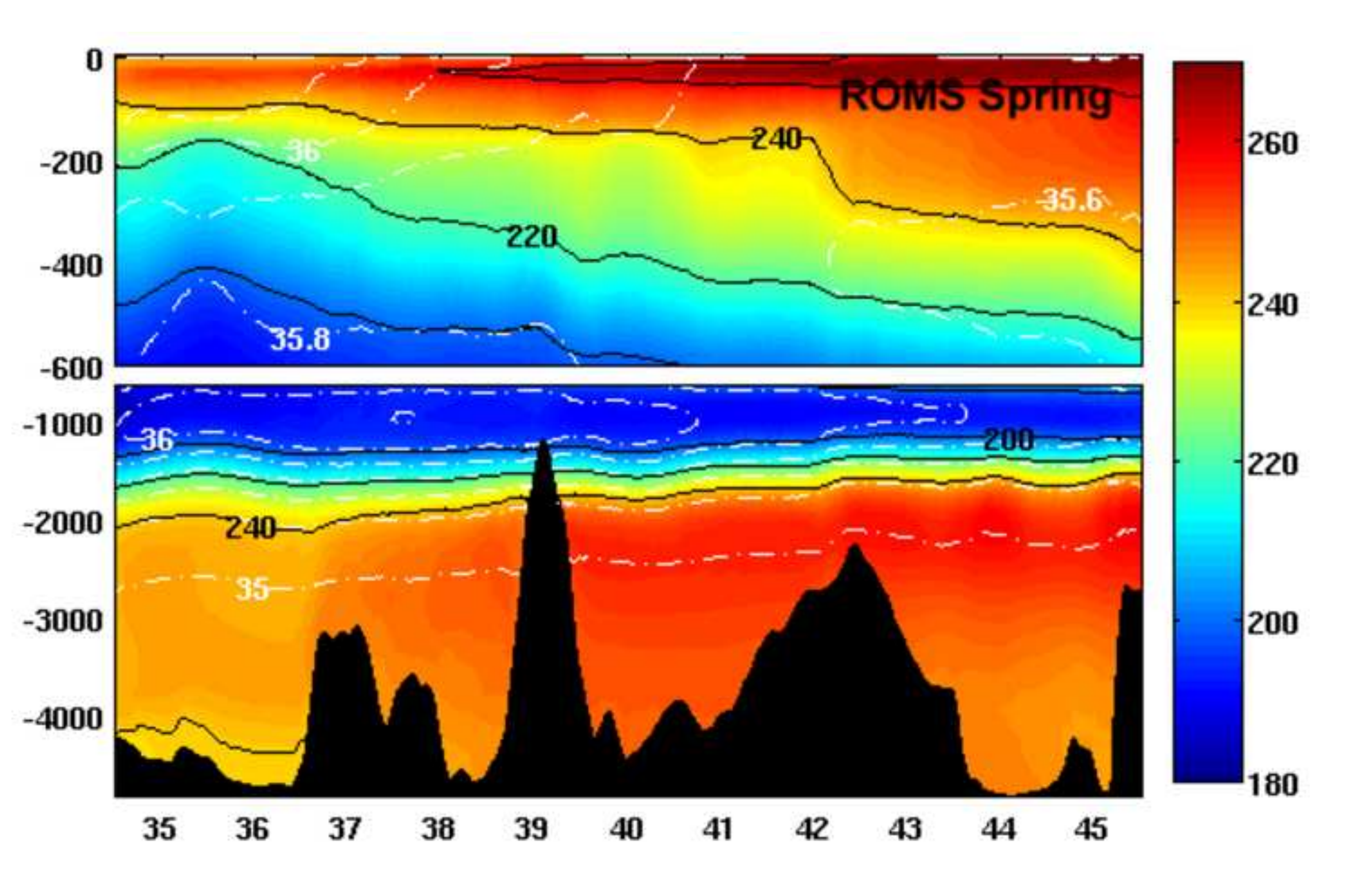

260

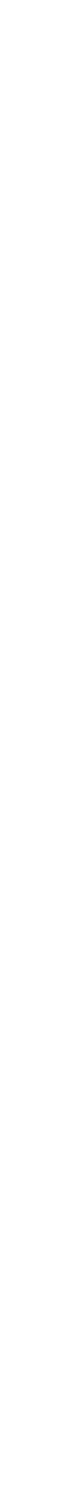

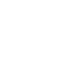




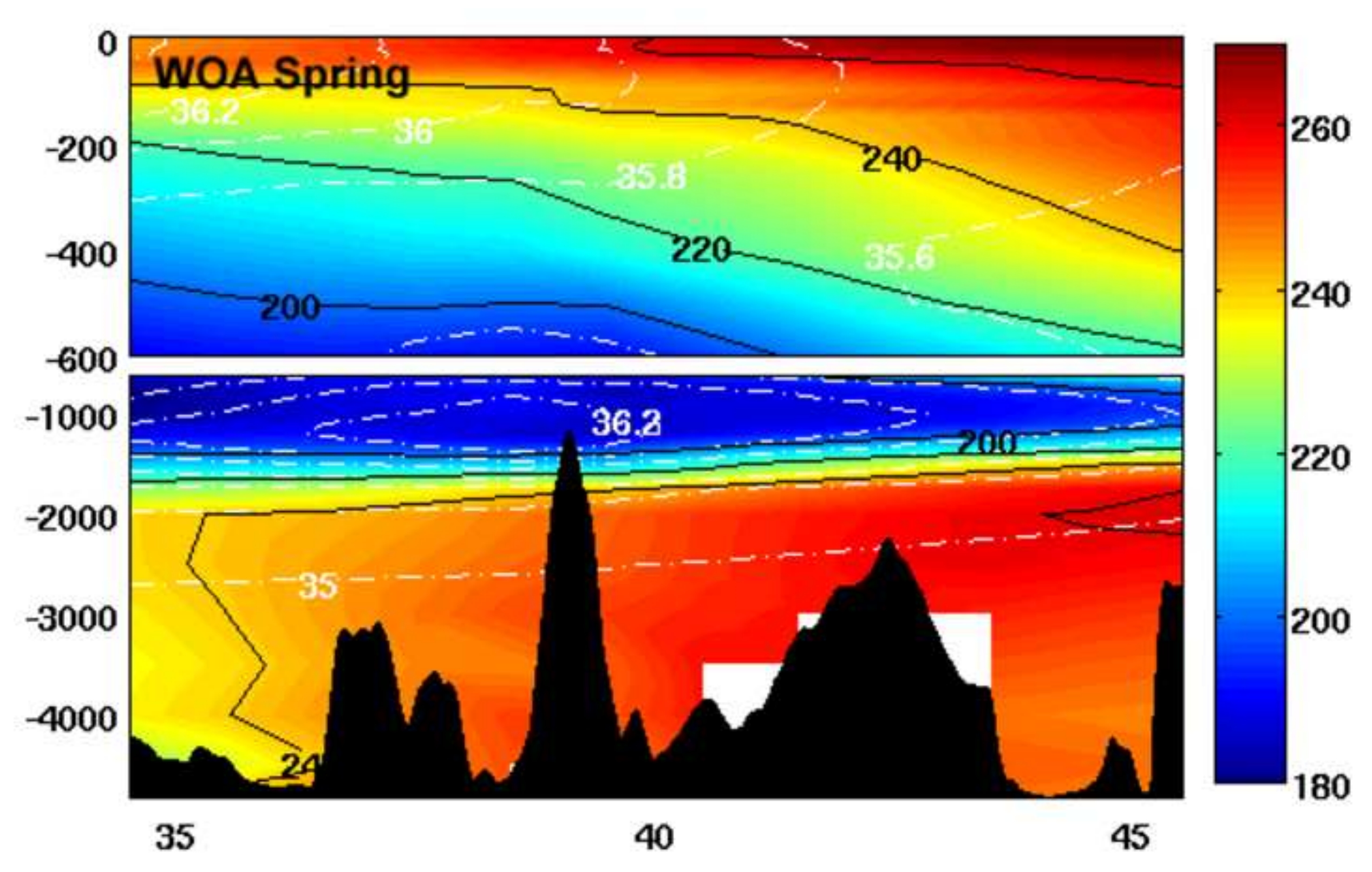

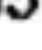

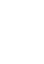




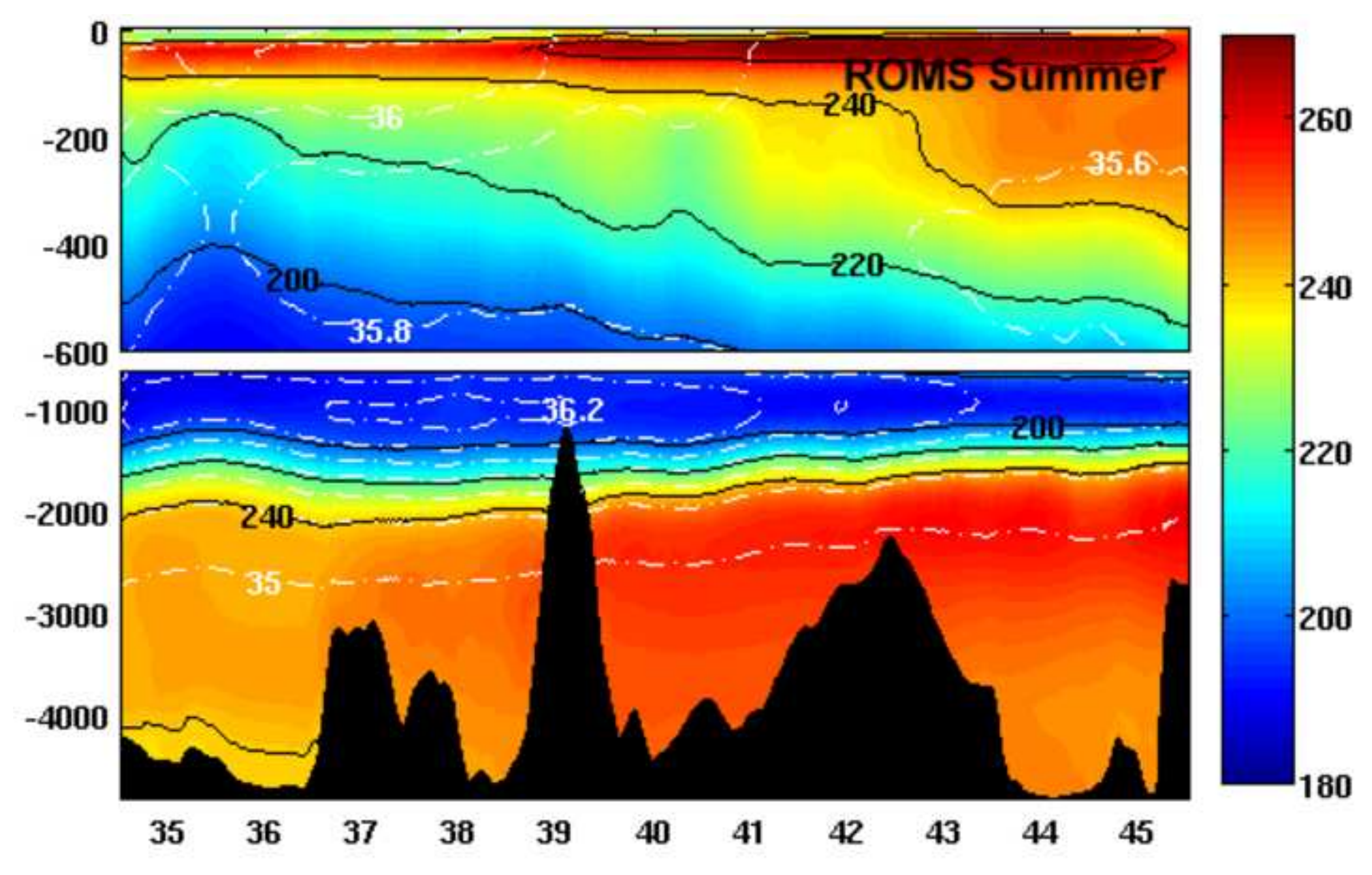

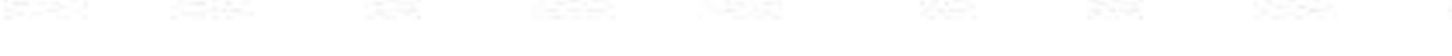




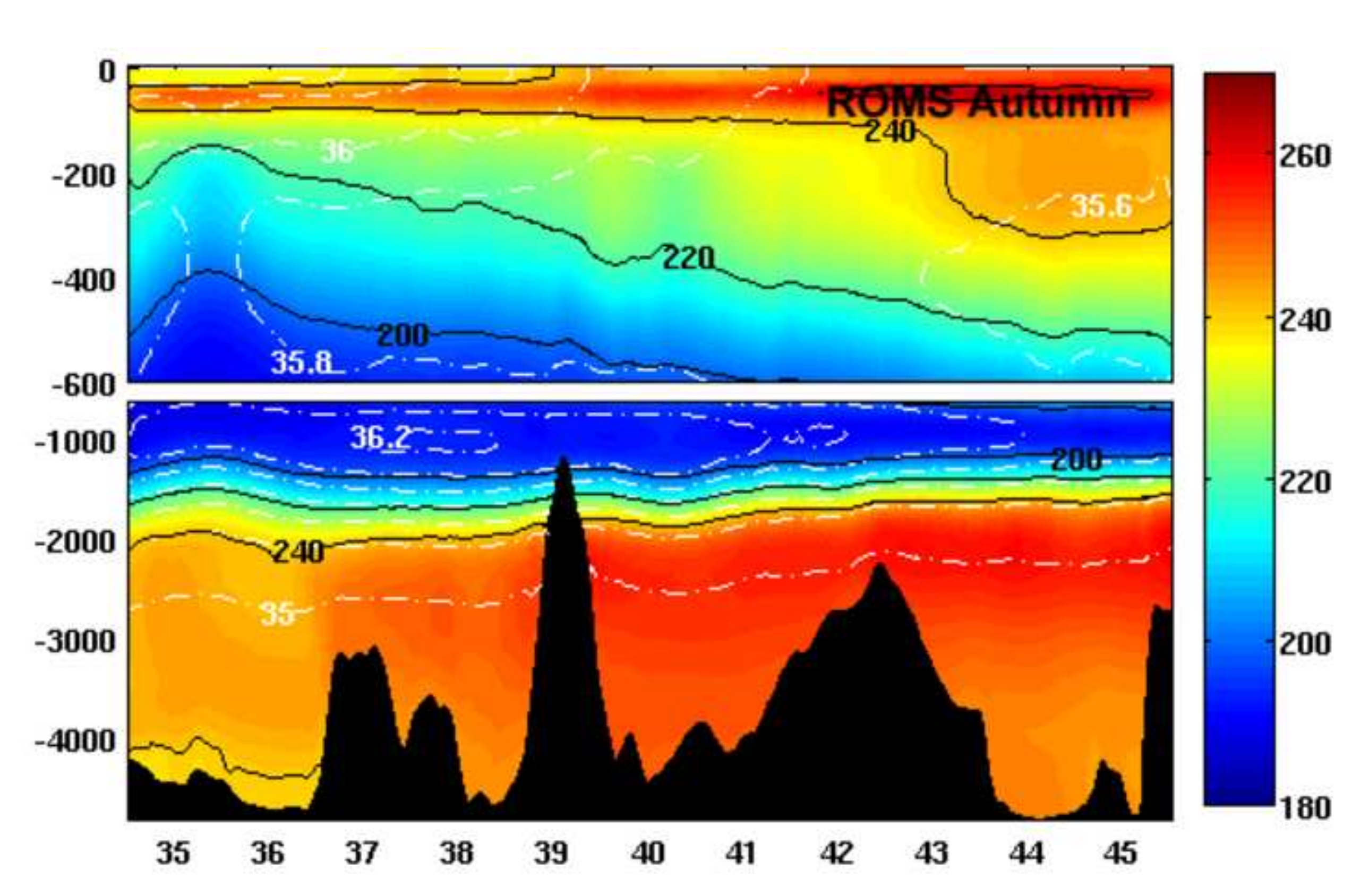$$
\text { - }
$$ 


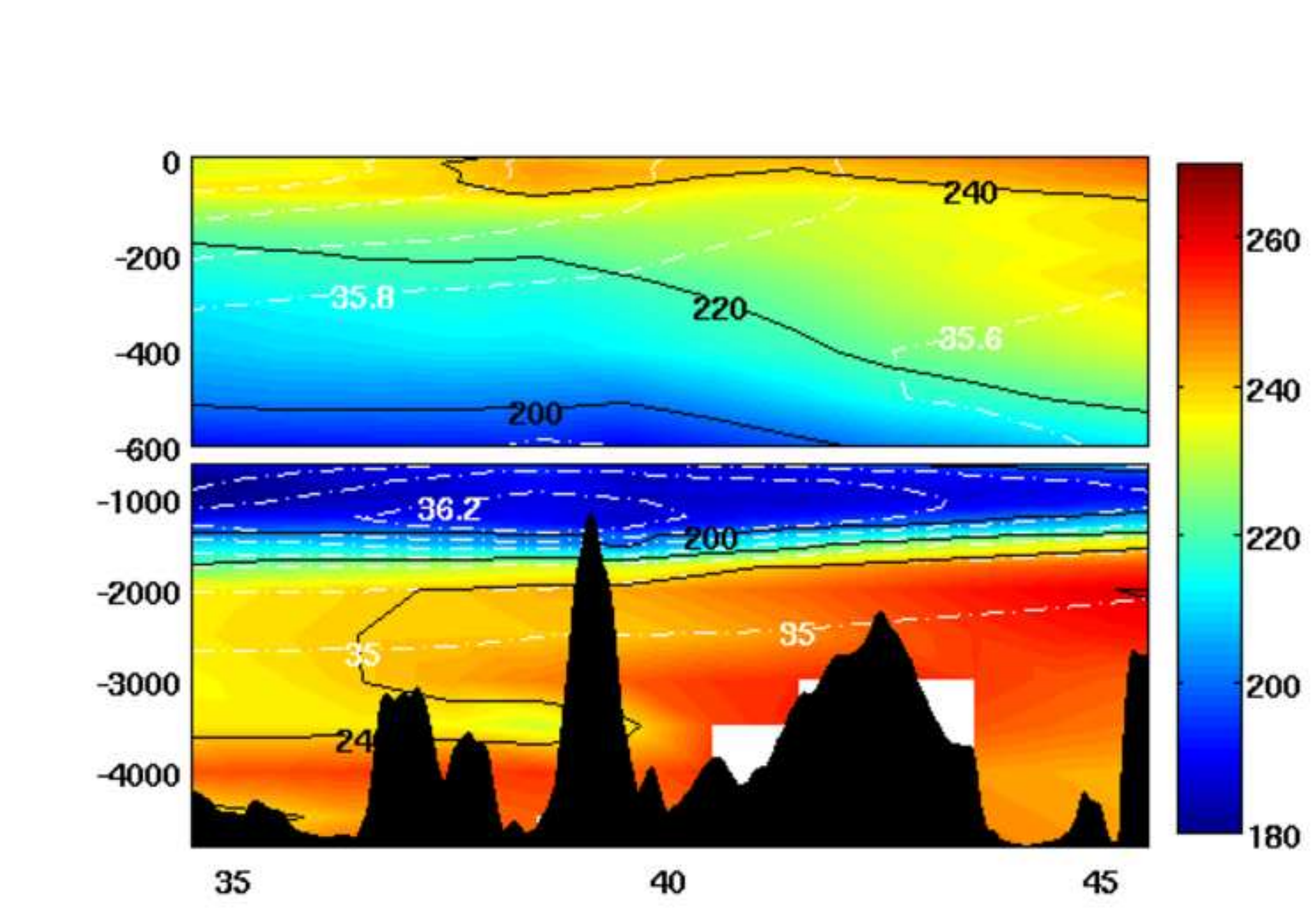

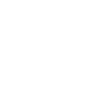

260
220
200
180

.




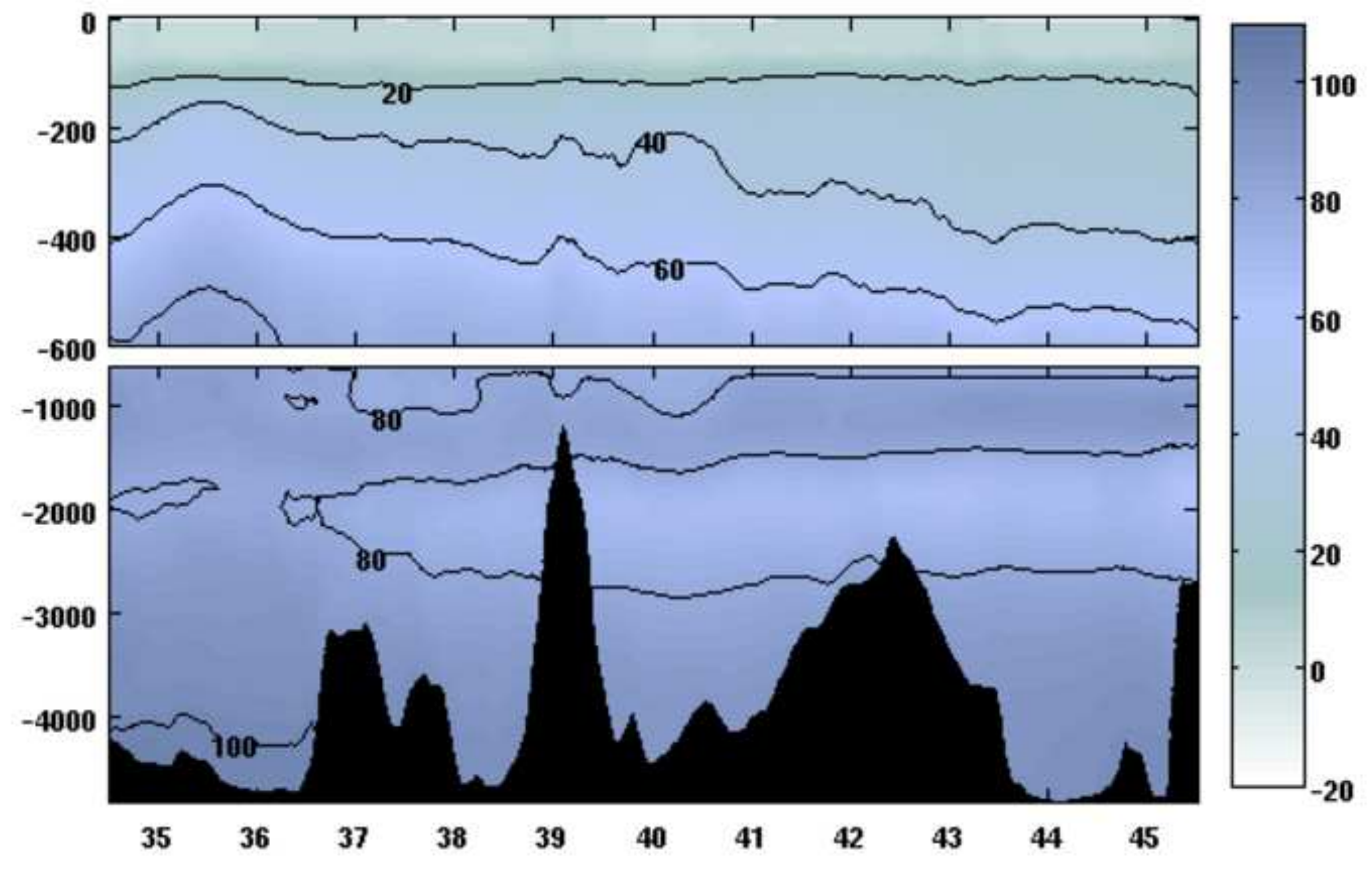
35
$36-37$

38

40

$42 \quad 43$




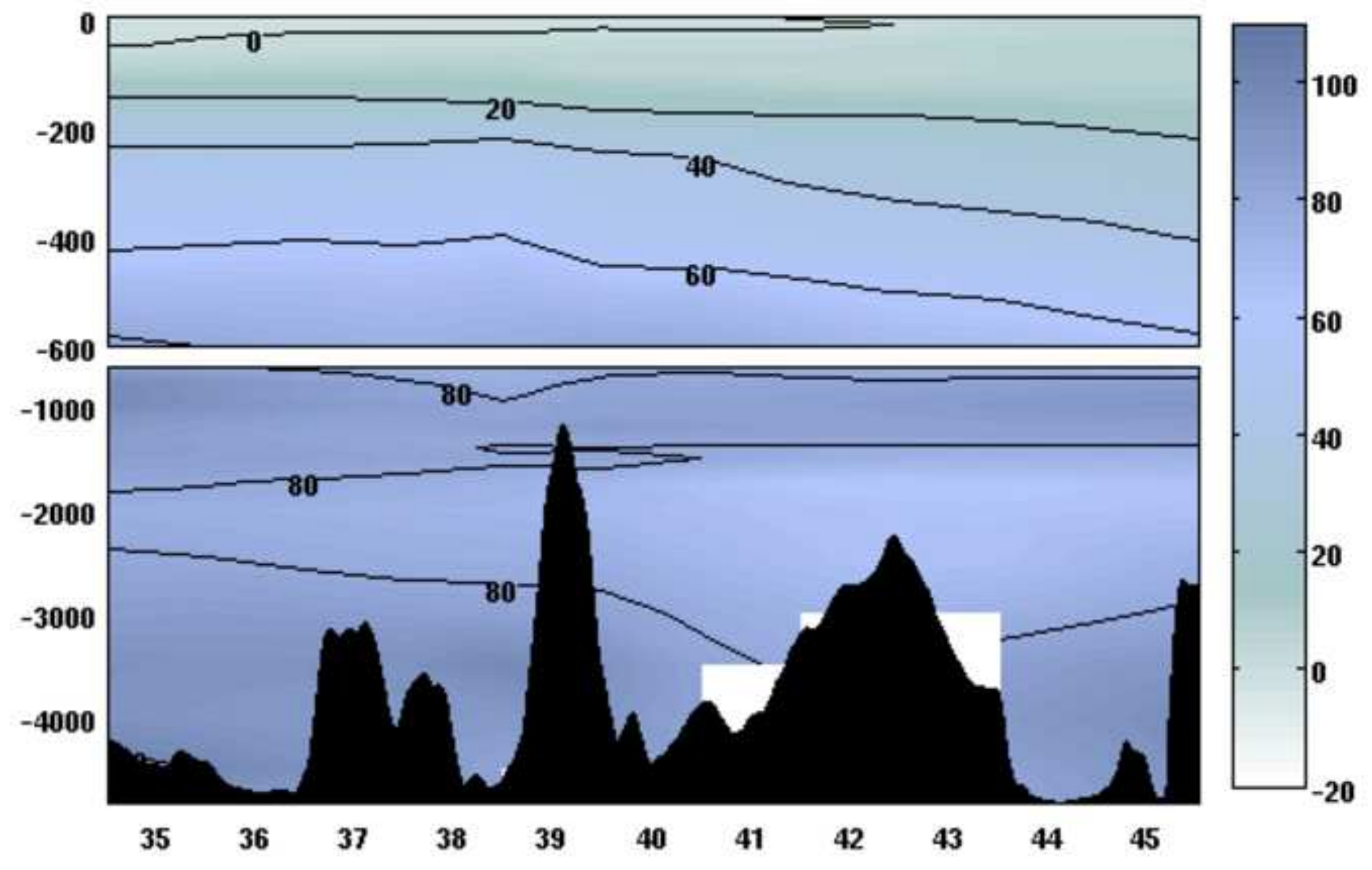
35

36

38

40

41

Figure
Click here to download high resolution image 


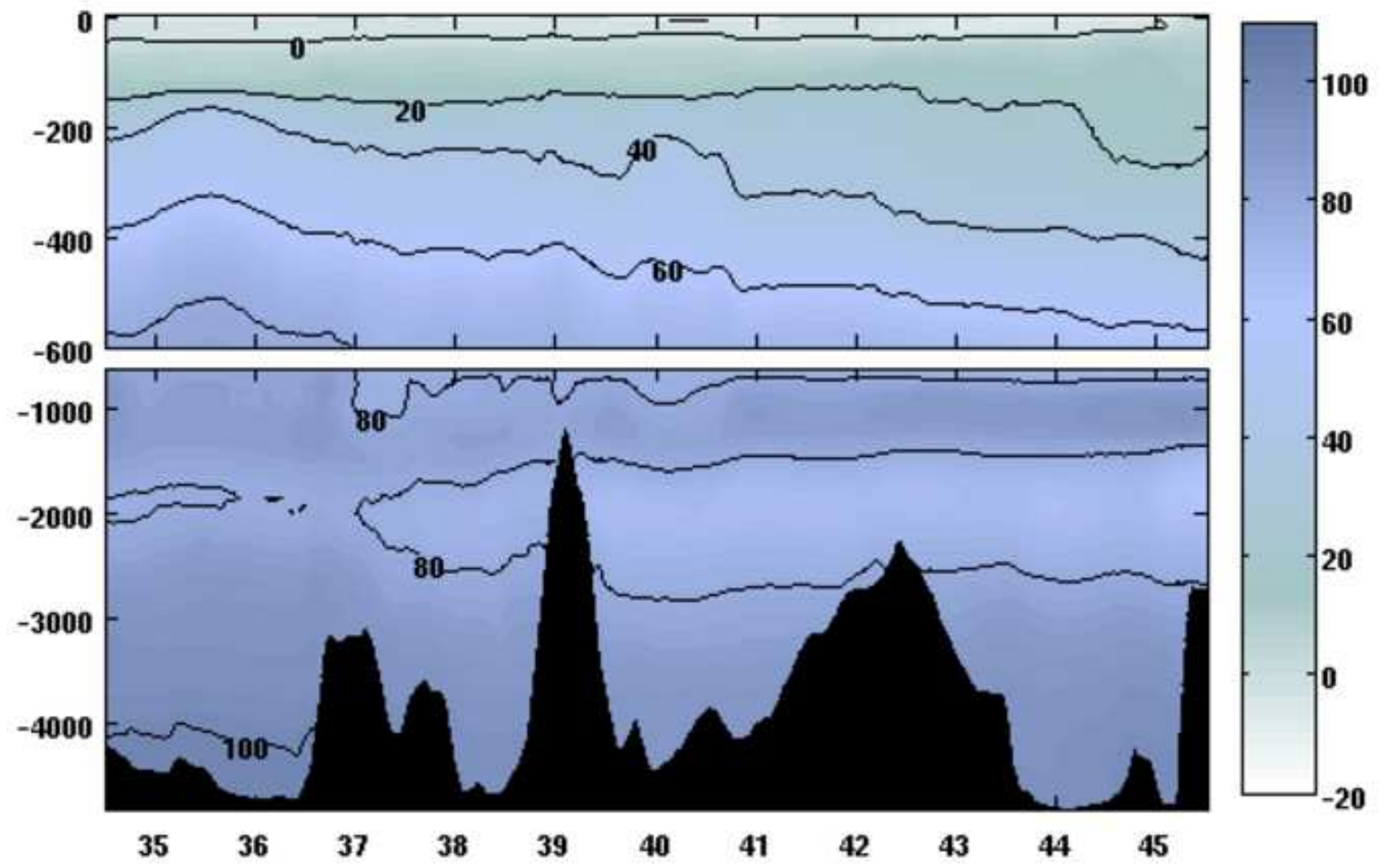
35
36
37
38
39

40

42




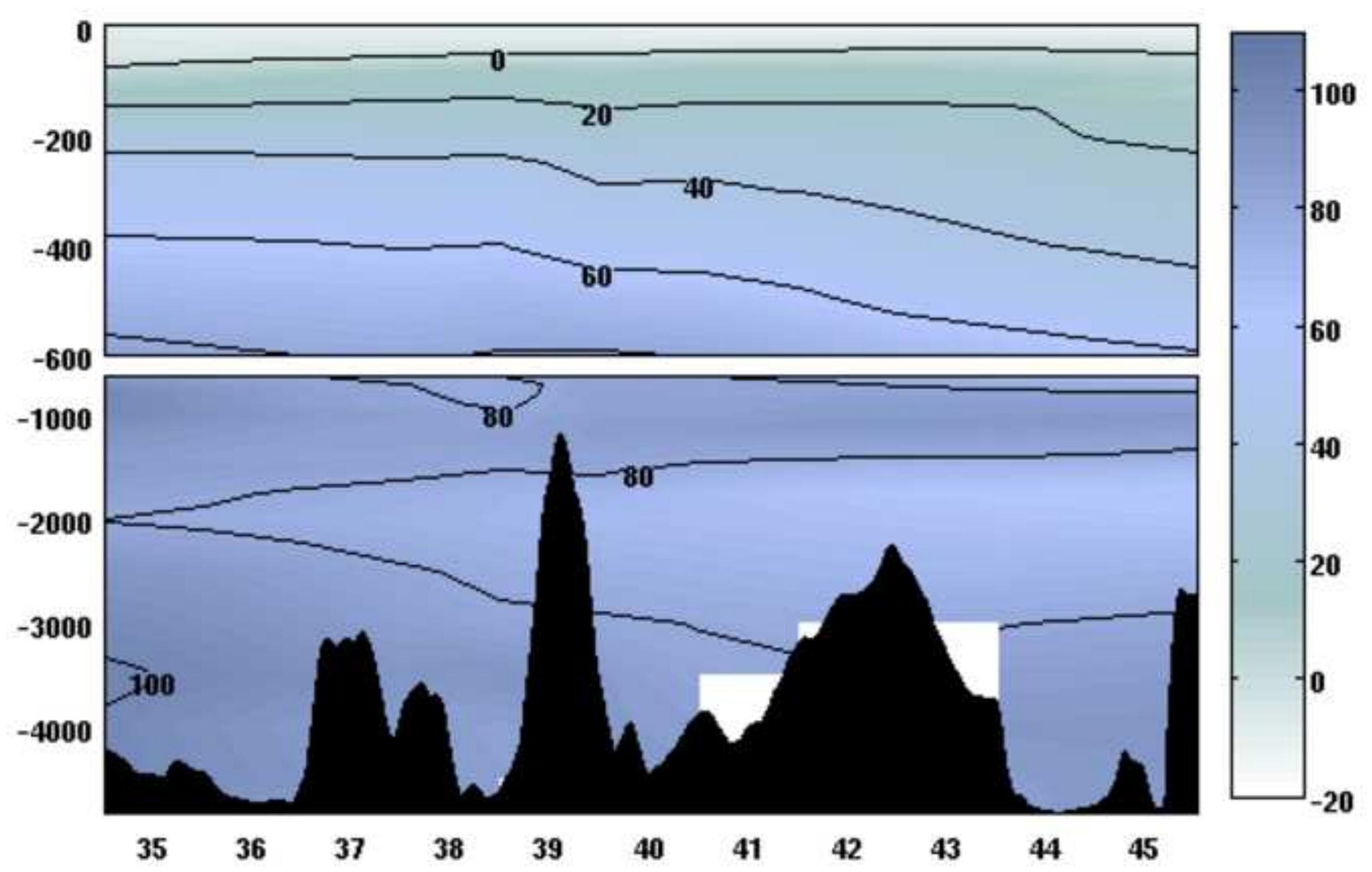
35
36
37

\begin{abstract}
.
\end{abstract}

41




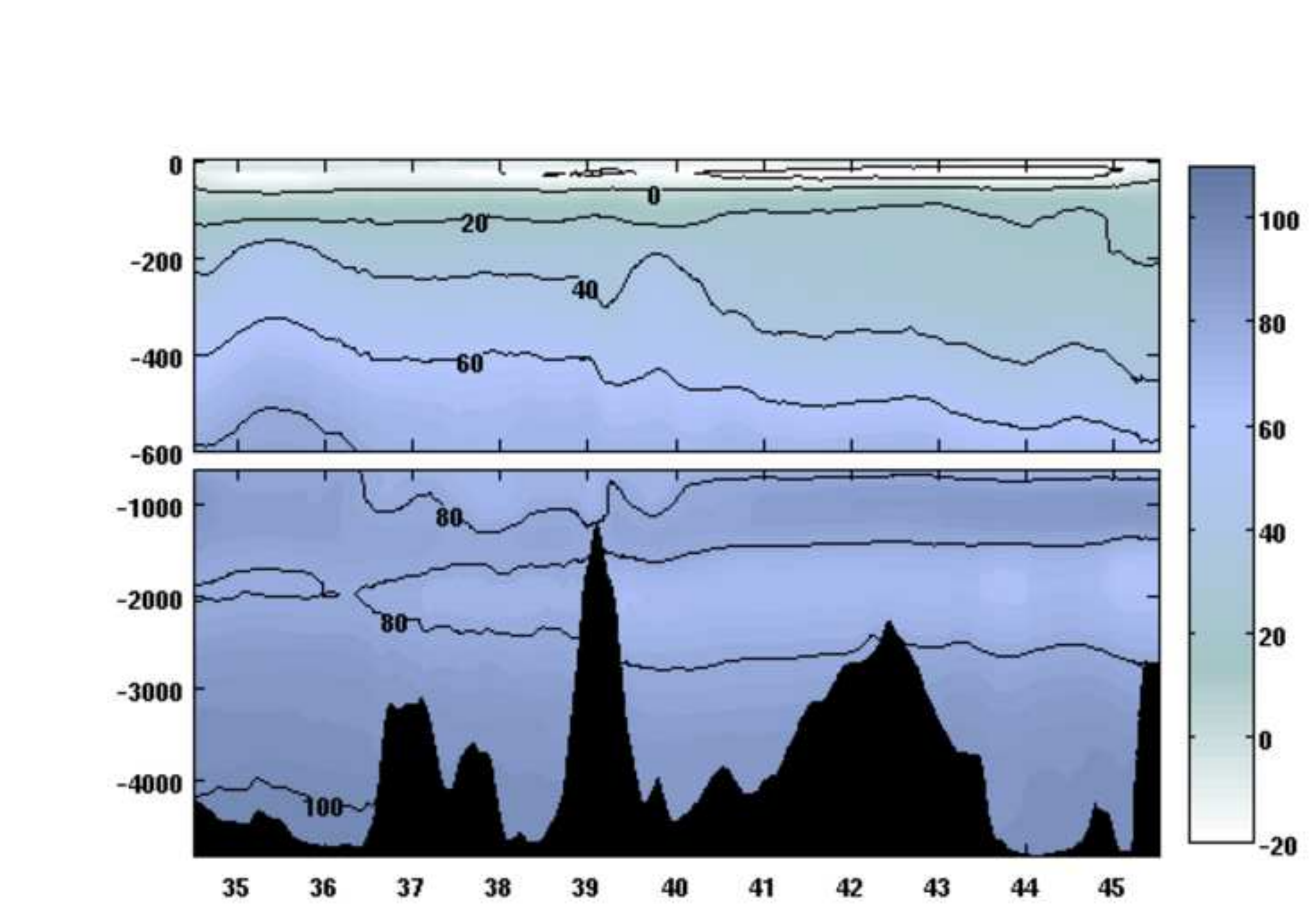

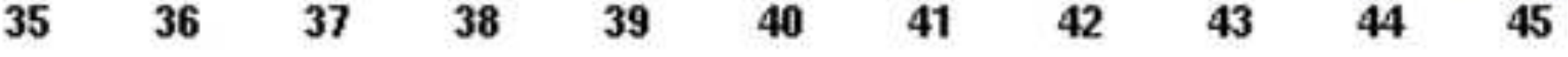

,

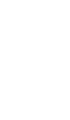




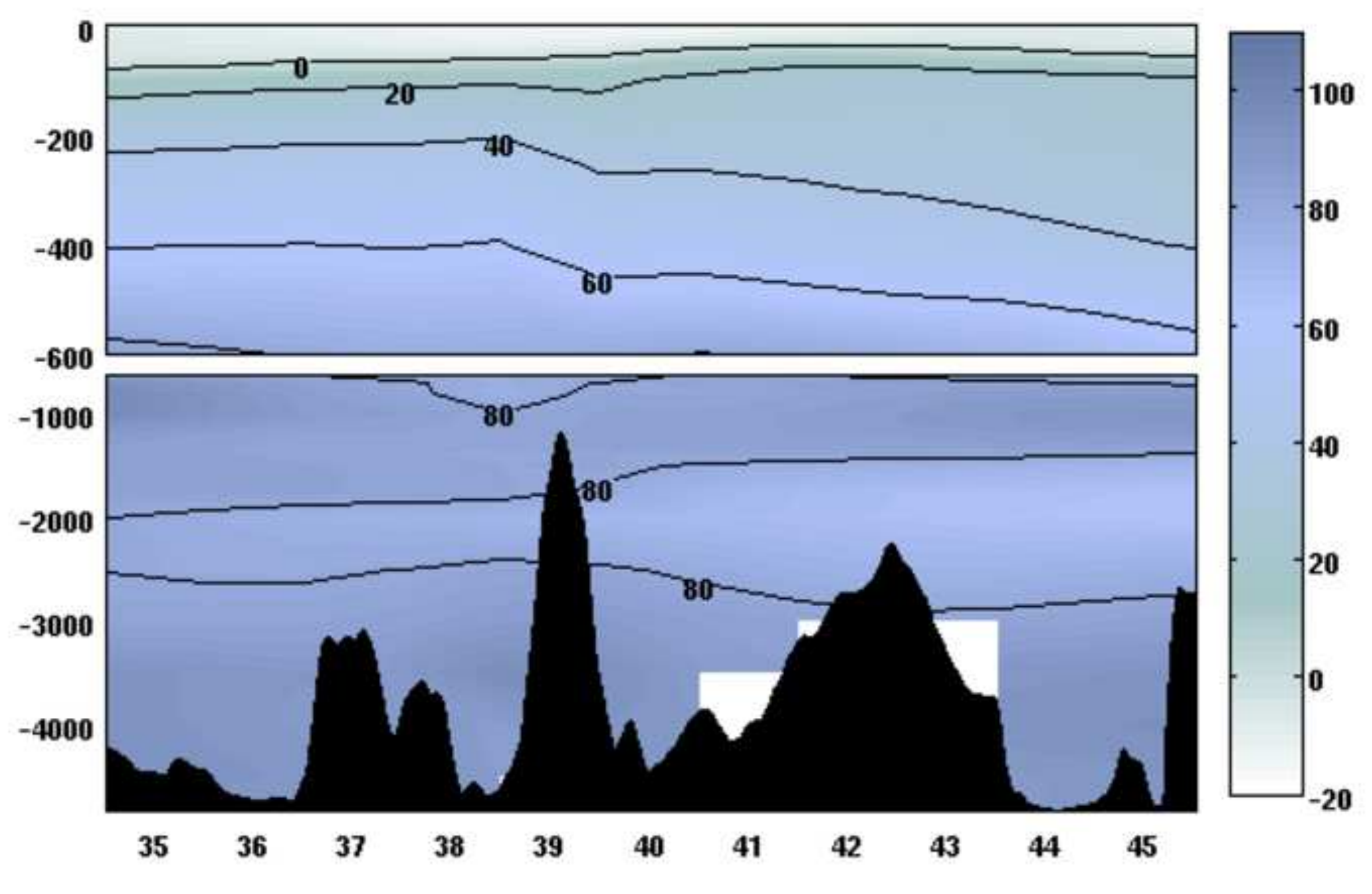
35

36

\begin{abstract}
$\begin{array}{lll}37 & 38 & 39\end{array}$
\end{abstract}
40

4142




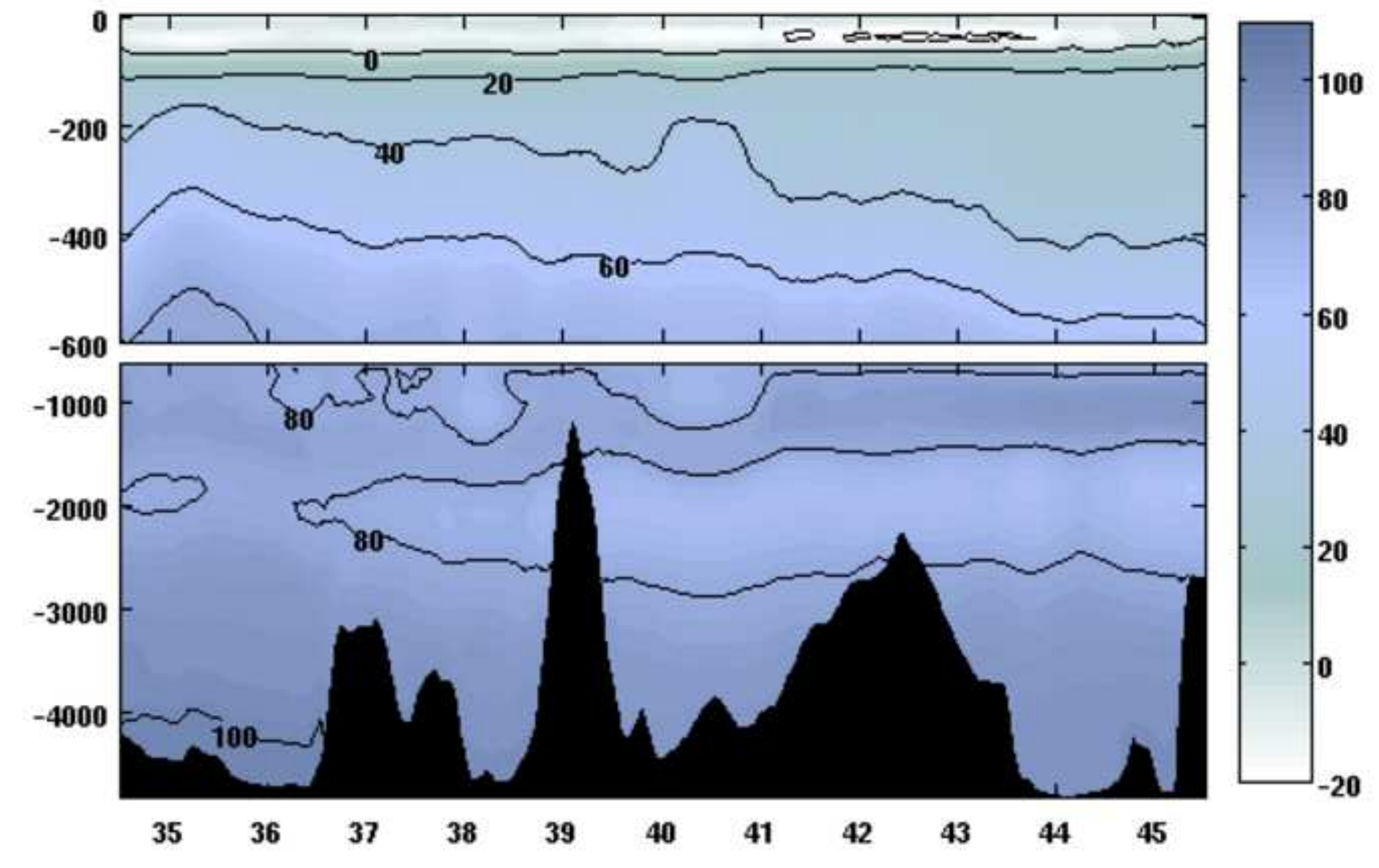
35
$36-37$
$38-39$

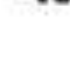

$41 \quad 43$
4

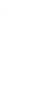




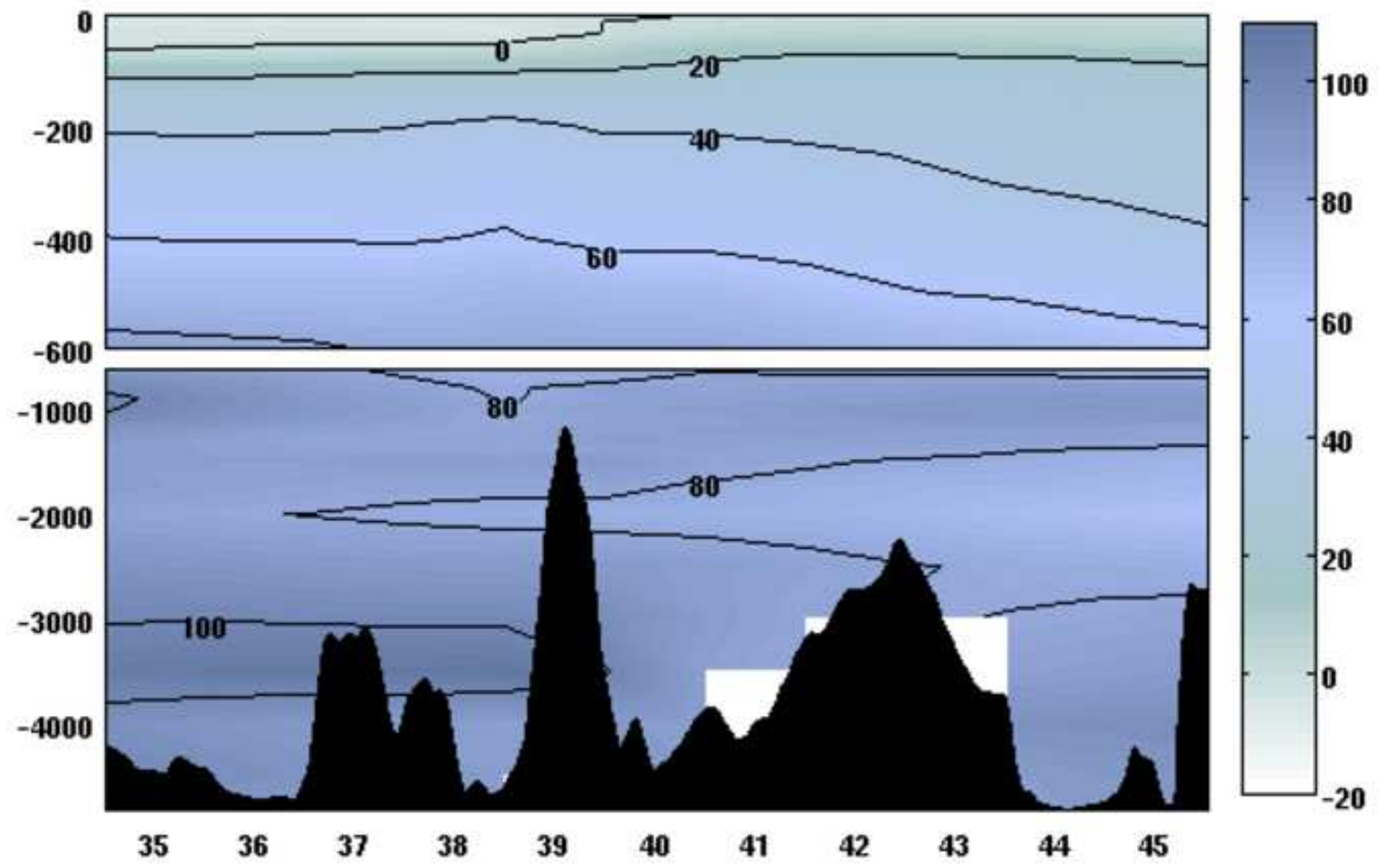
35
36
37

40

43

45 

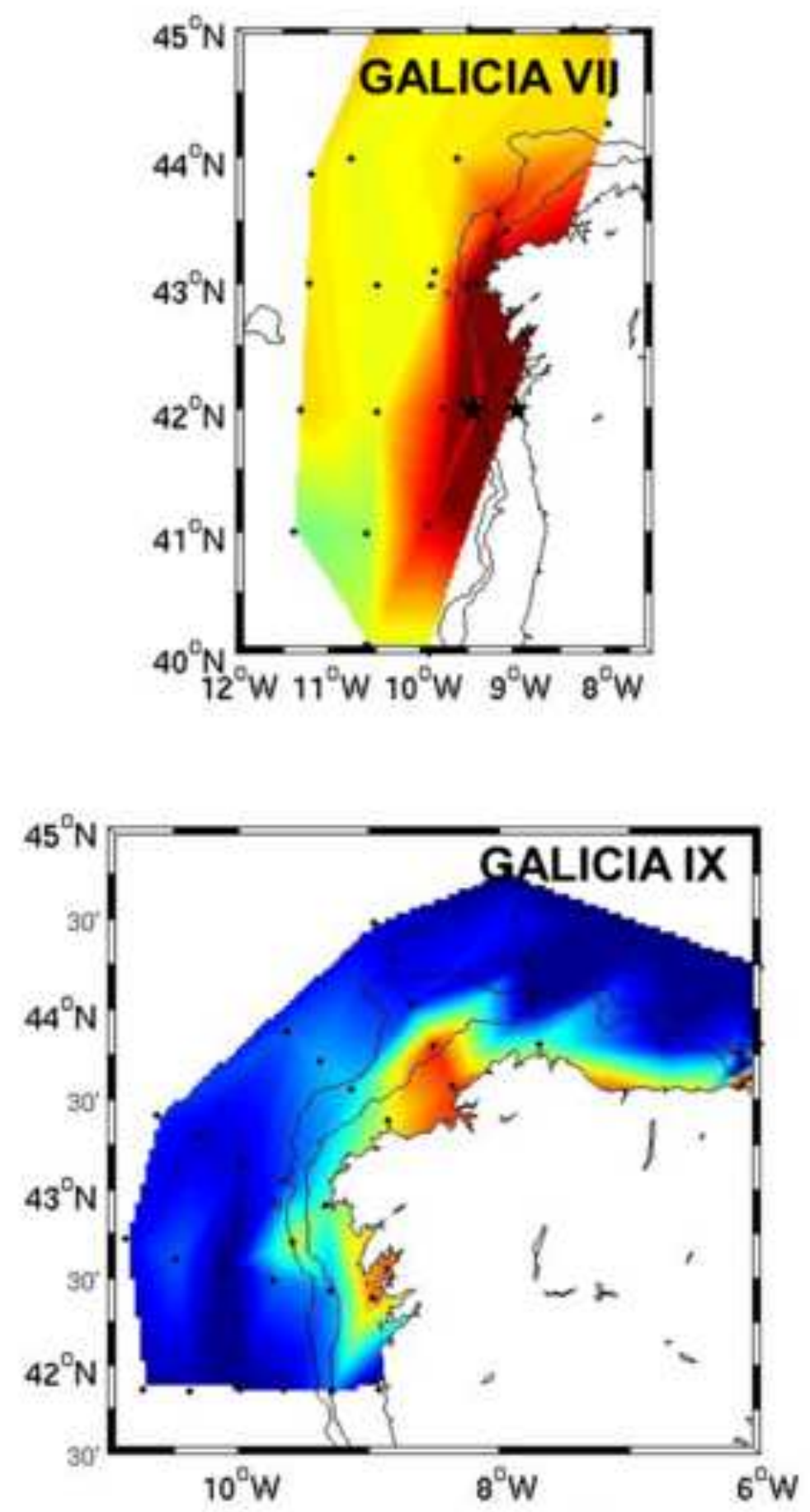
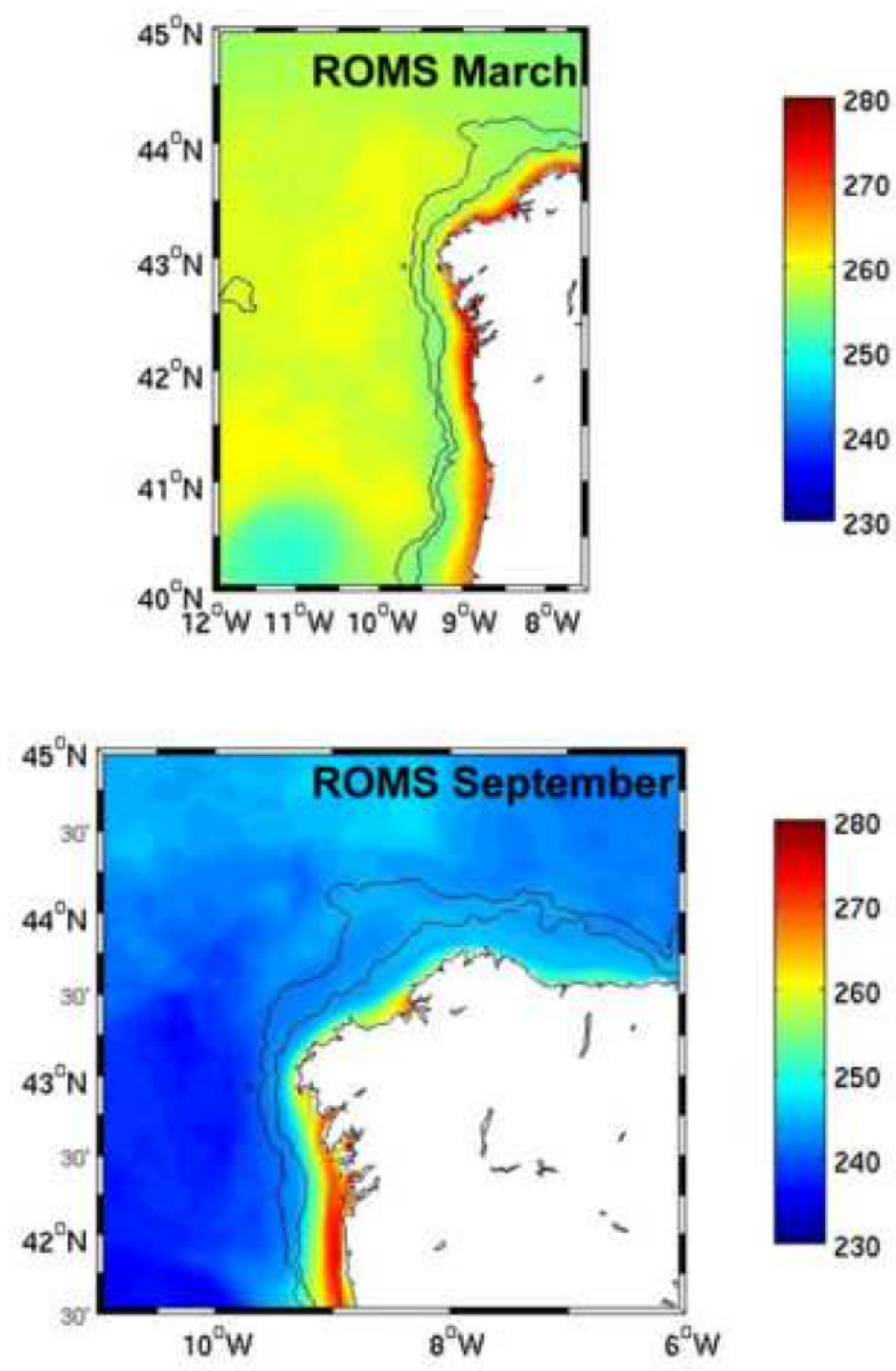
Click here to download high resolution image
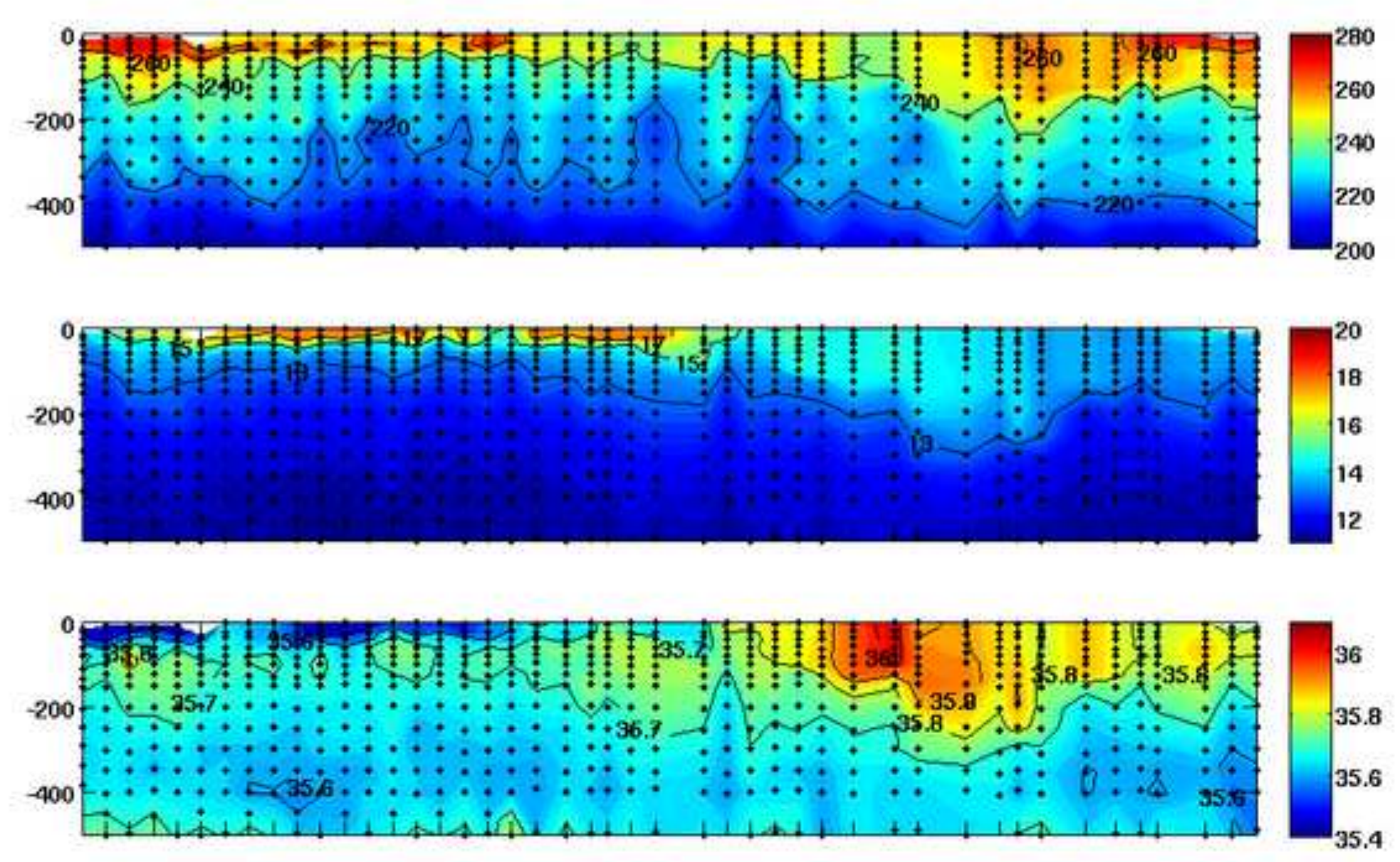

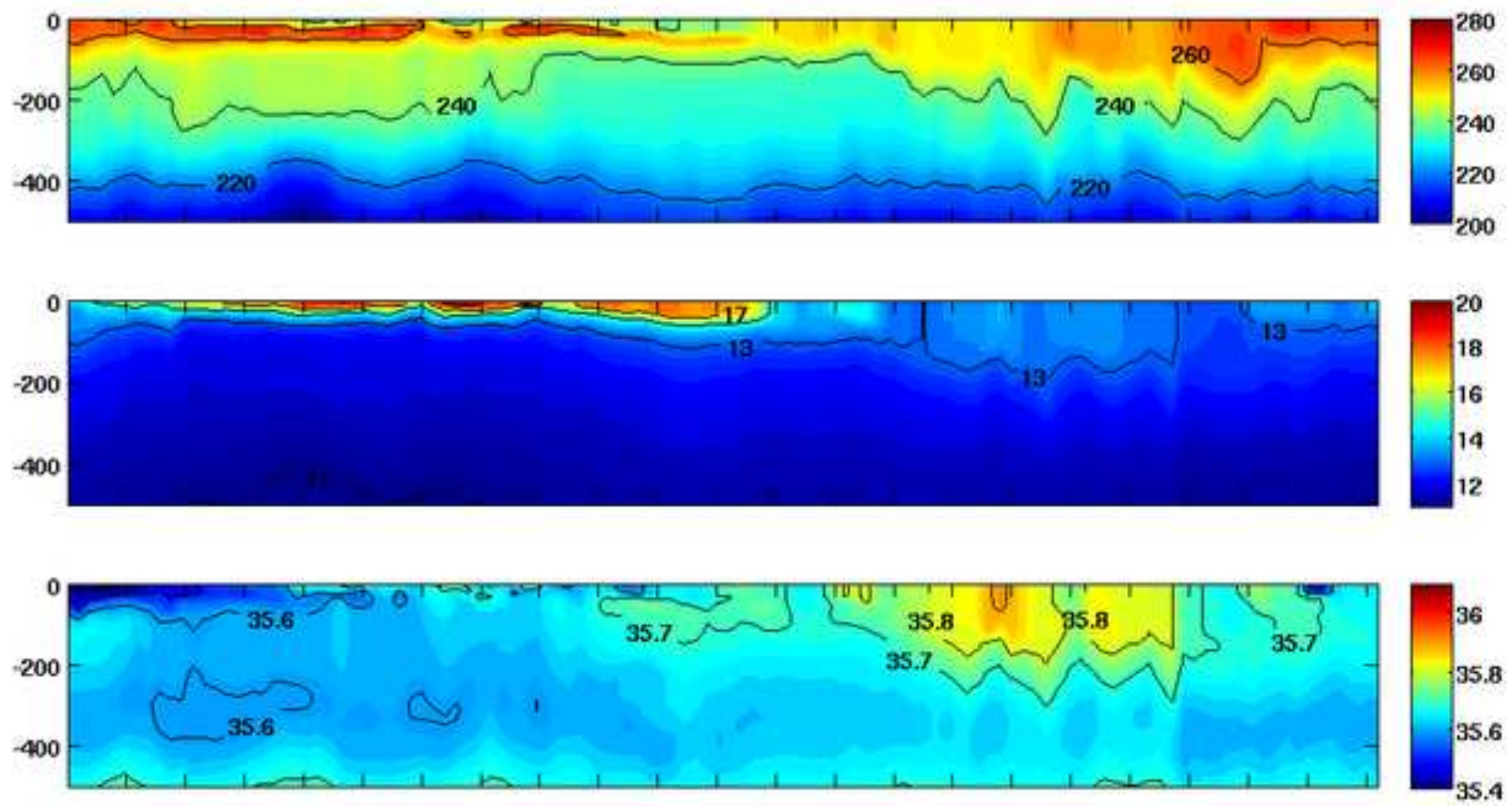
Click here to download high resolution image
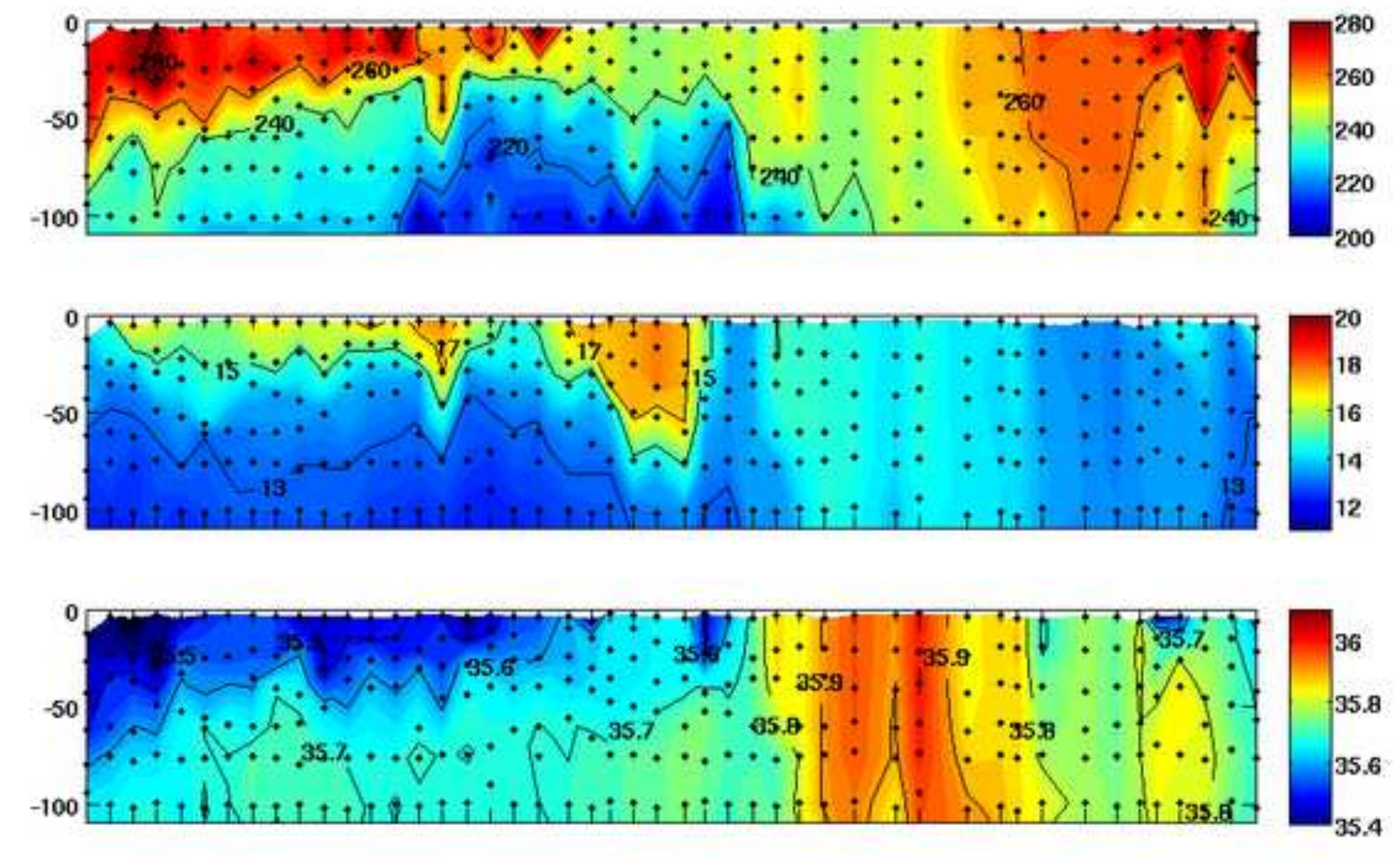

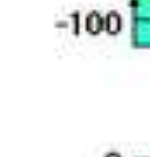



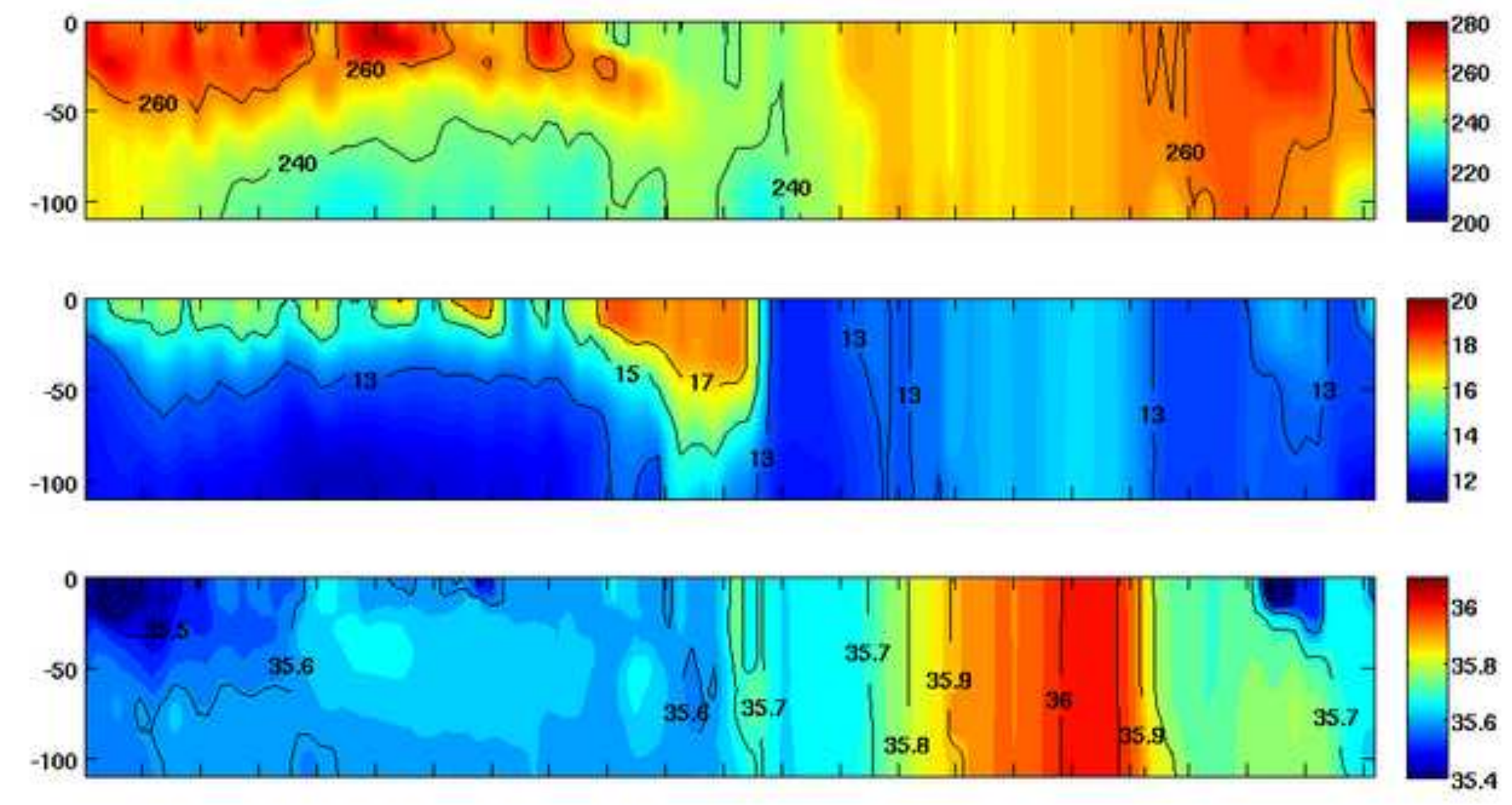


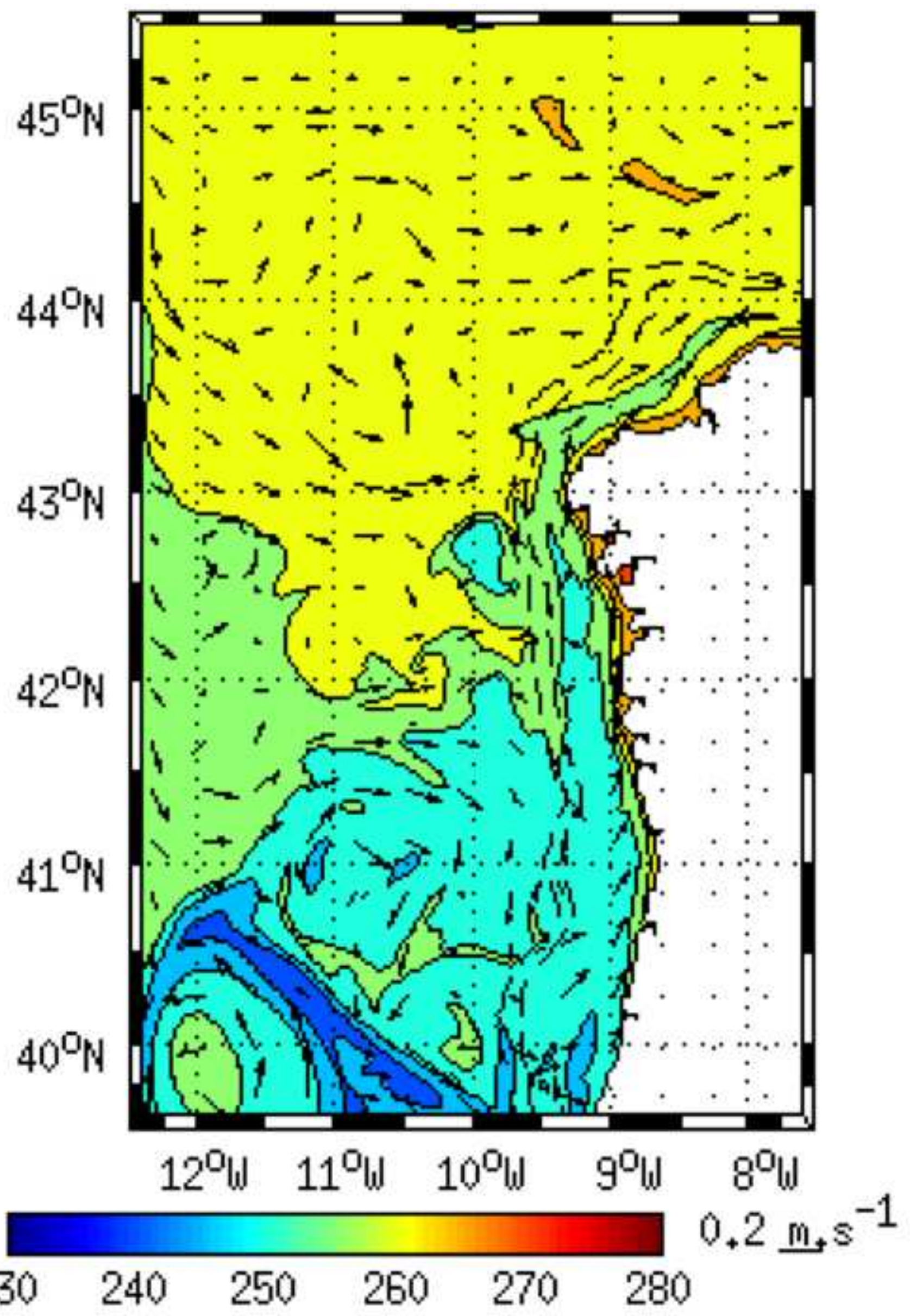

$\begin{array}{llllll}230 & 240 & 250 & 260 & 270 & 280\end{array}$ 

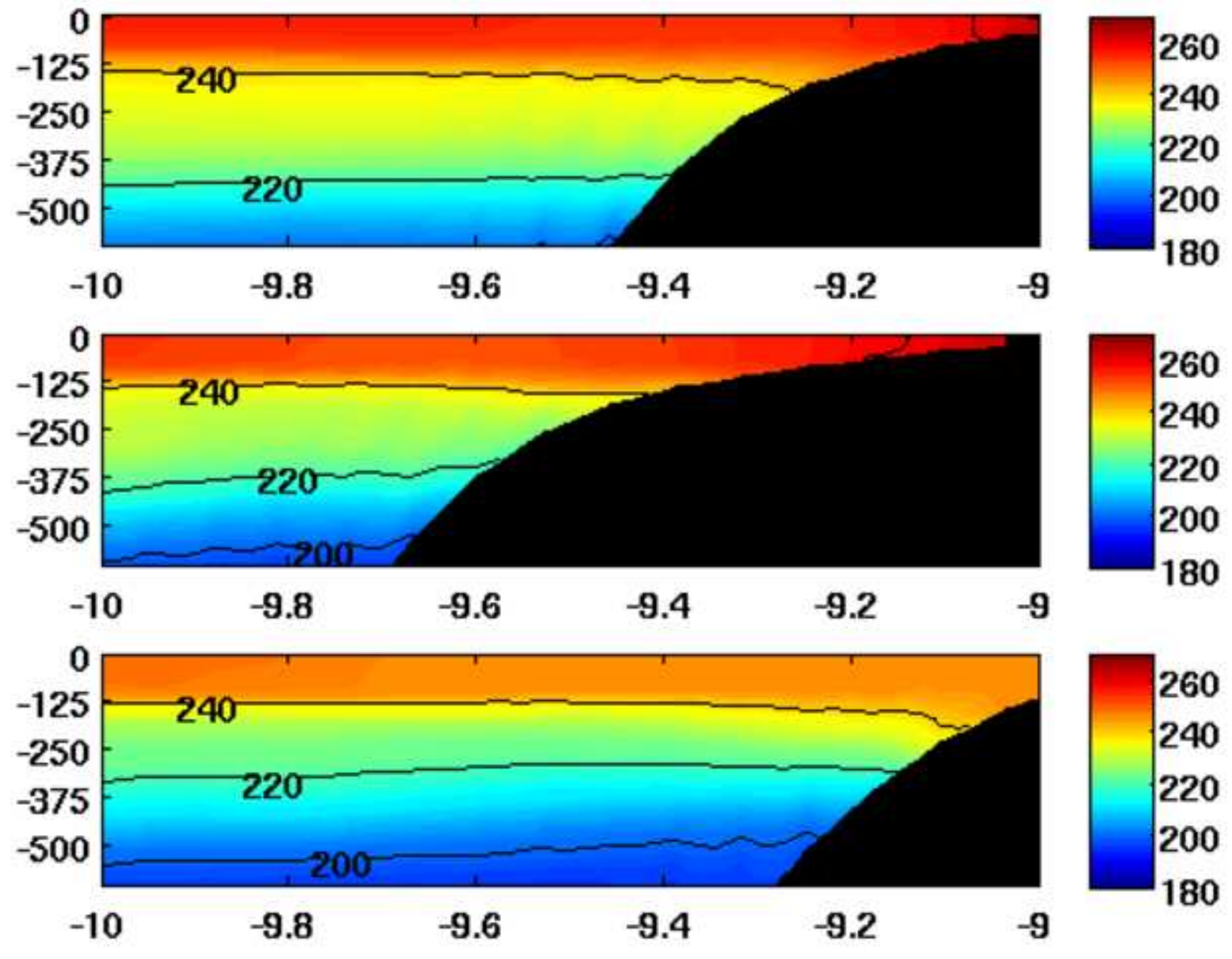

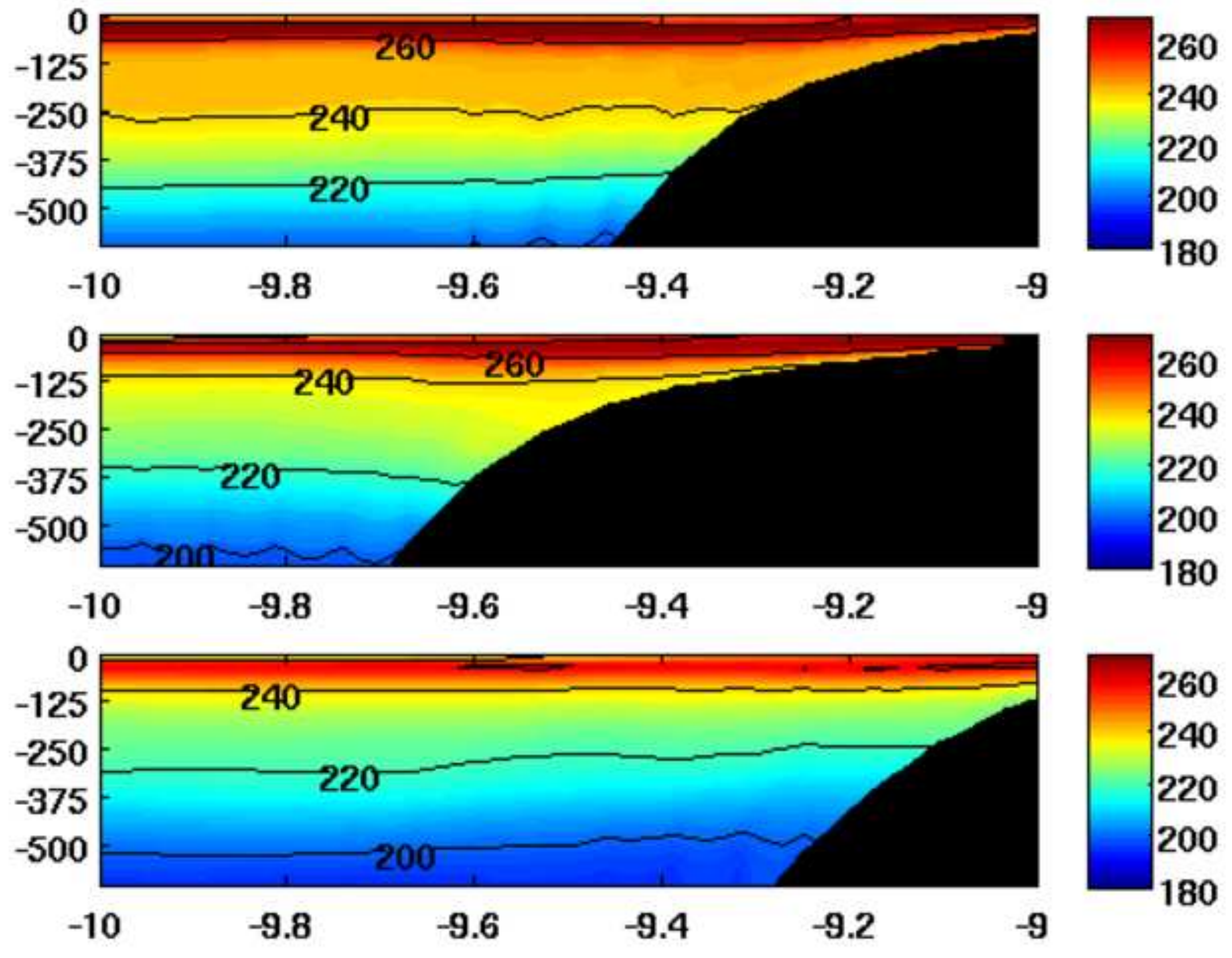

180 260 240 220 200 80 

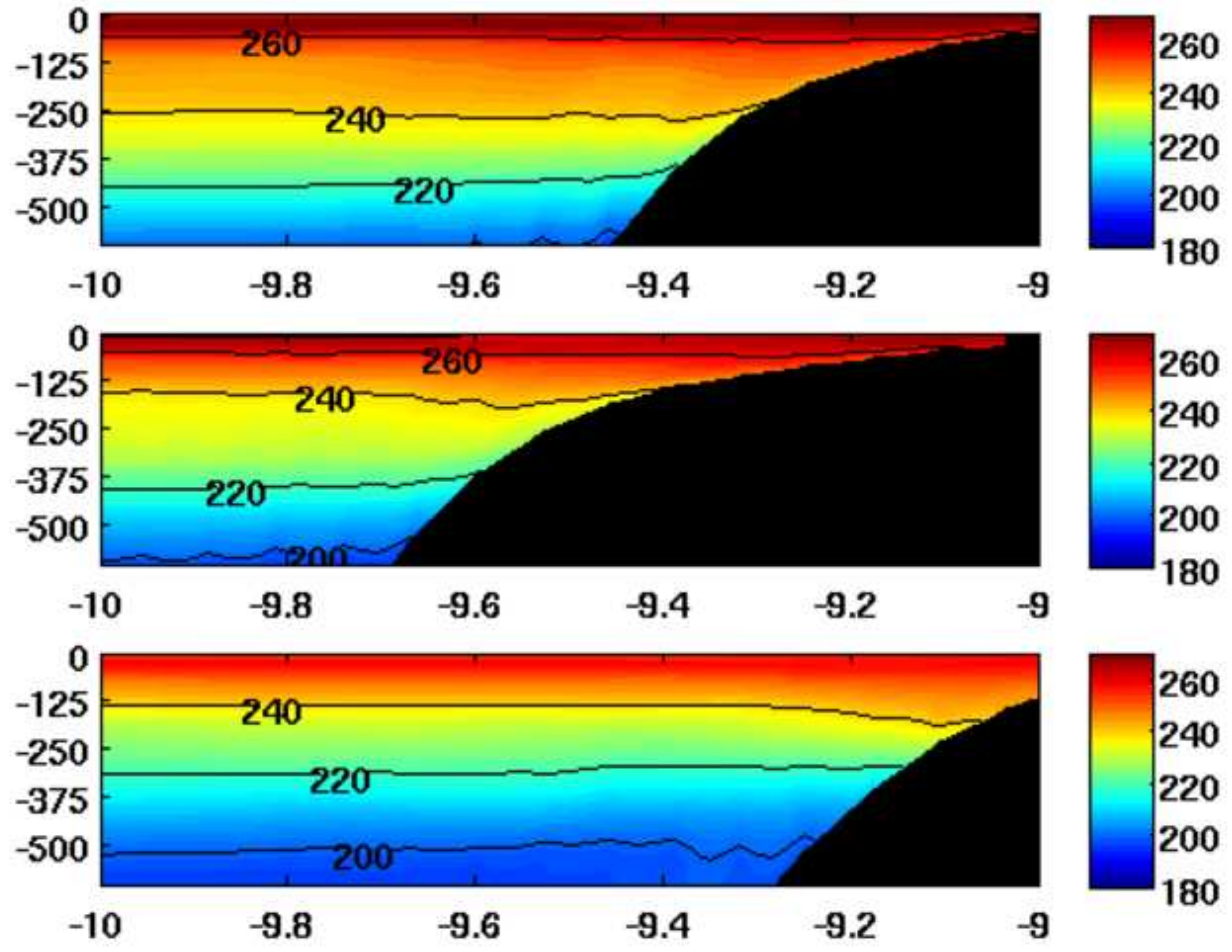

180 260 240 220 200 80 60 240 220 200 80 $-10$ $-9.8$ 

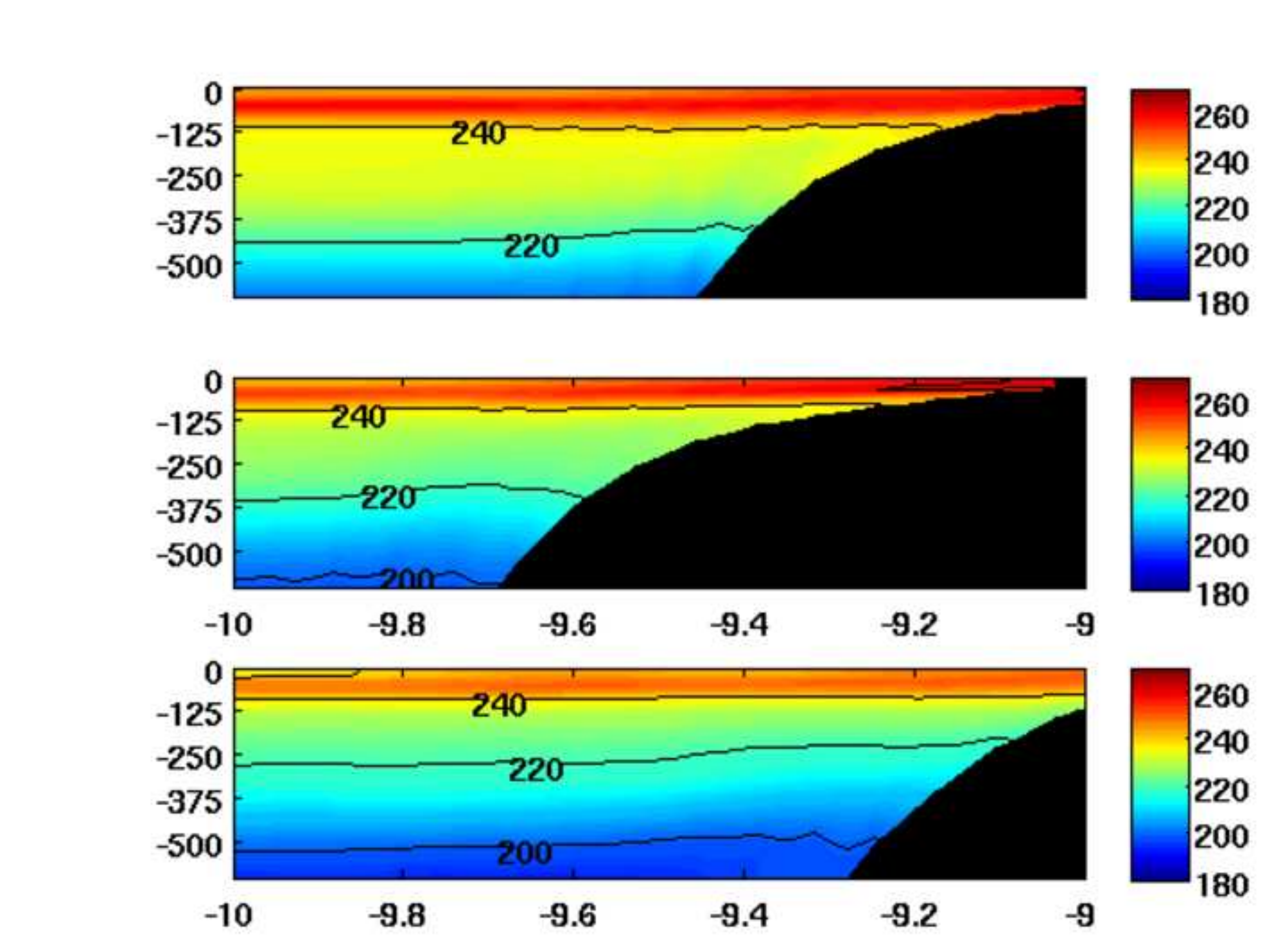
9

9 180 
Click here to download high resolution image
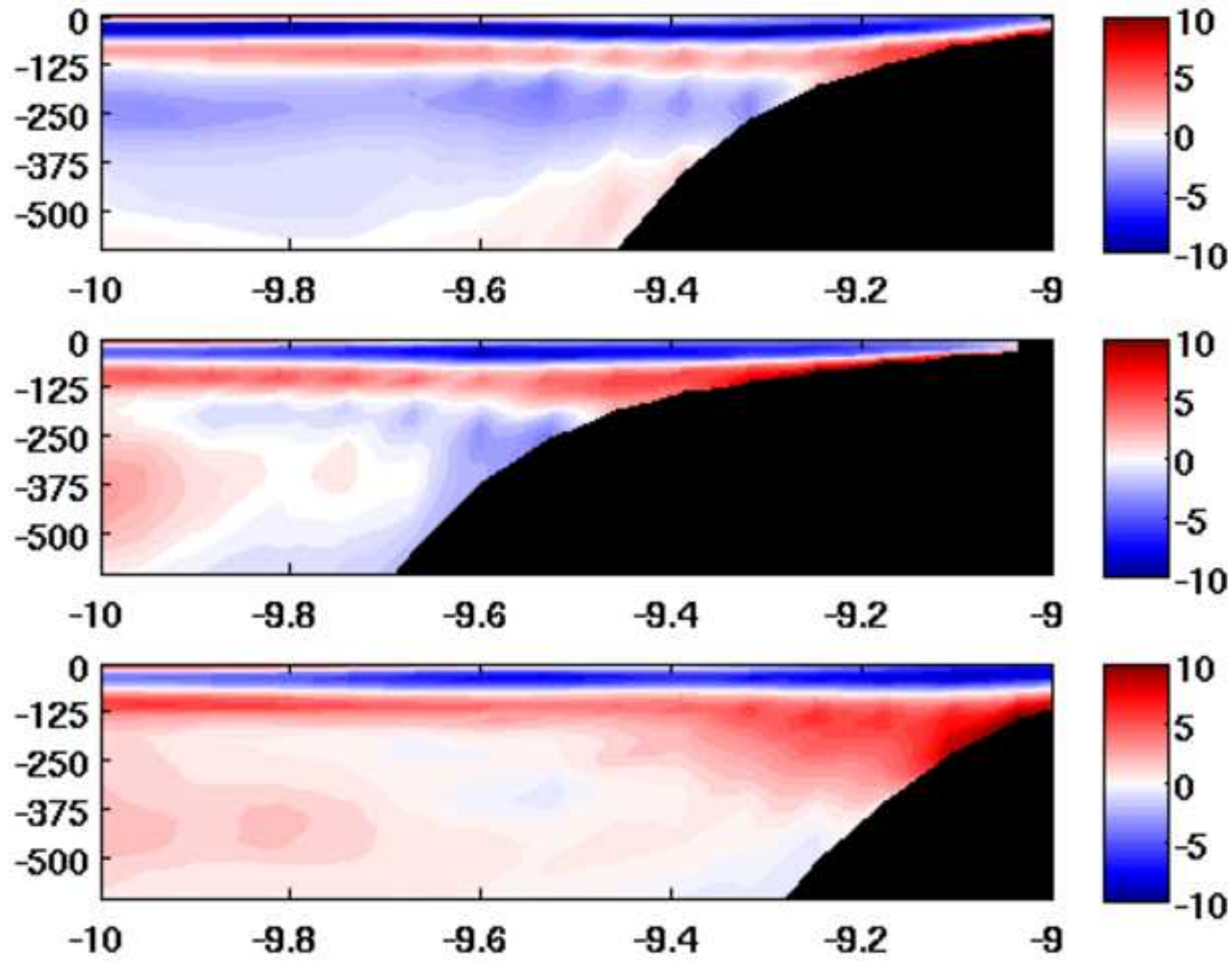

$$
-9
$$

\section{$-9$}



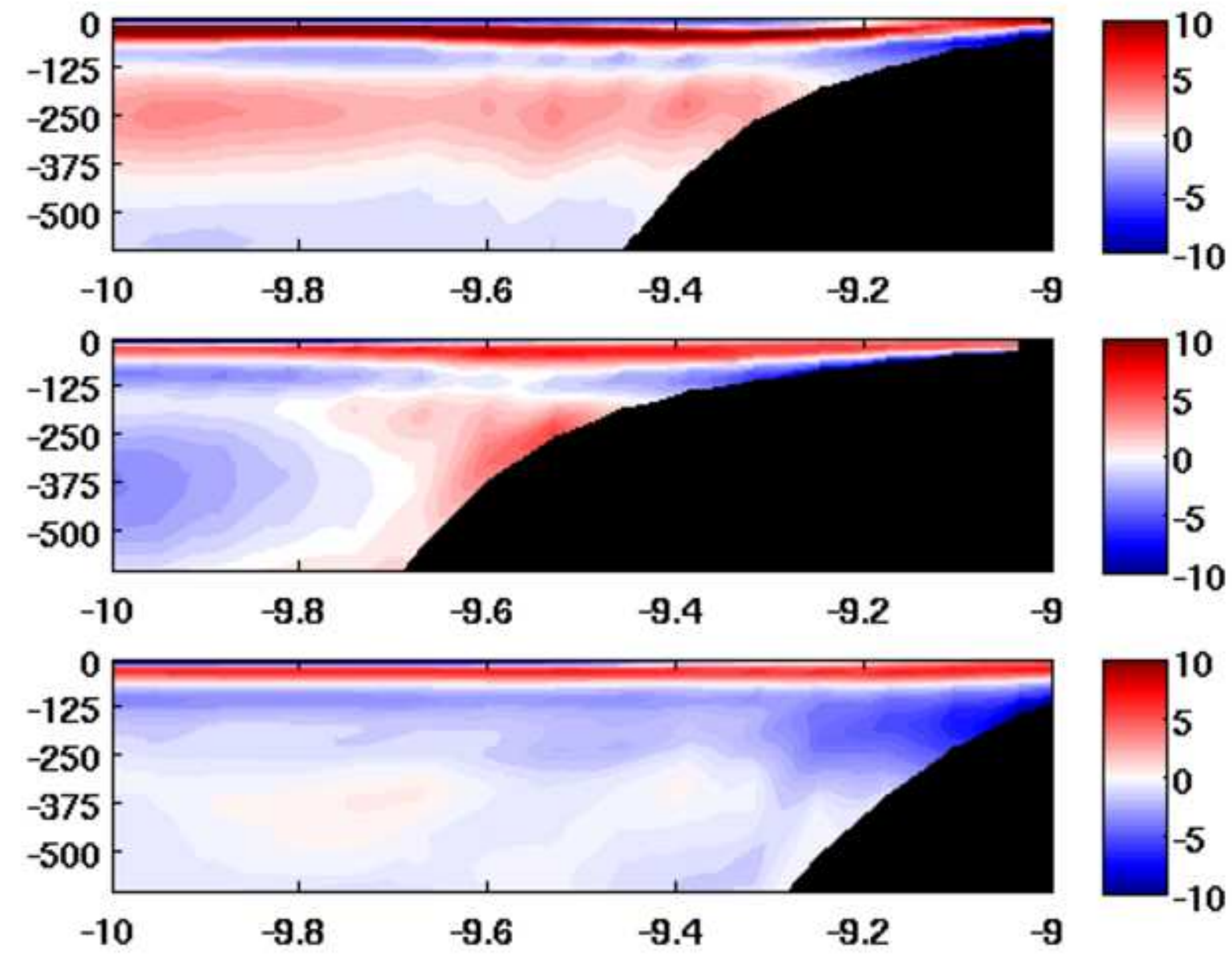

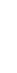




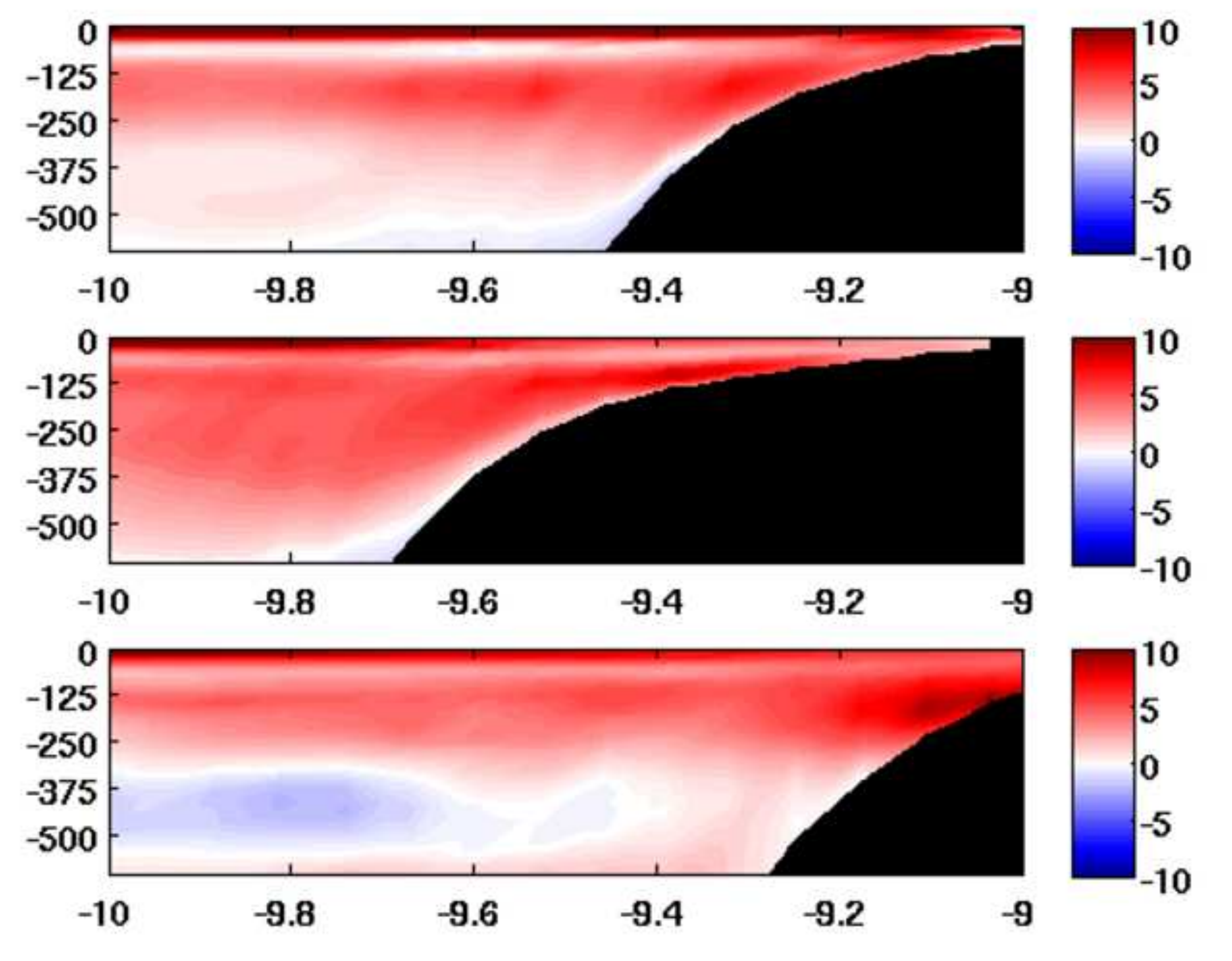

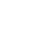




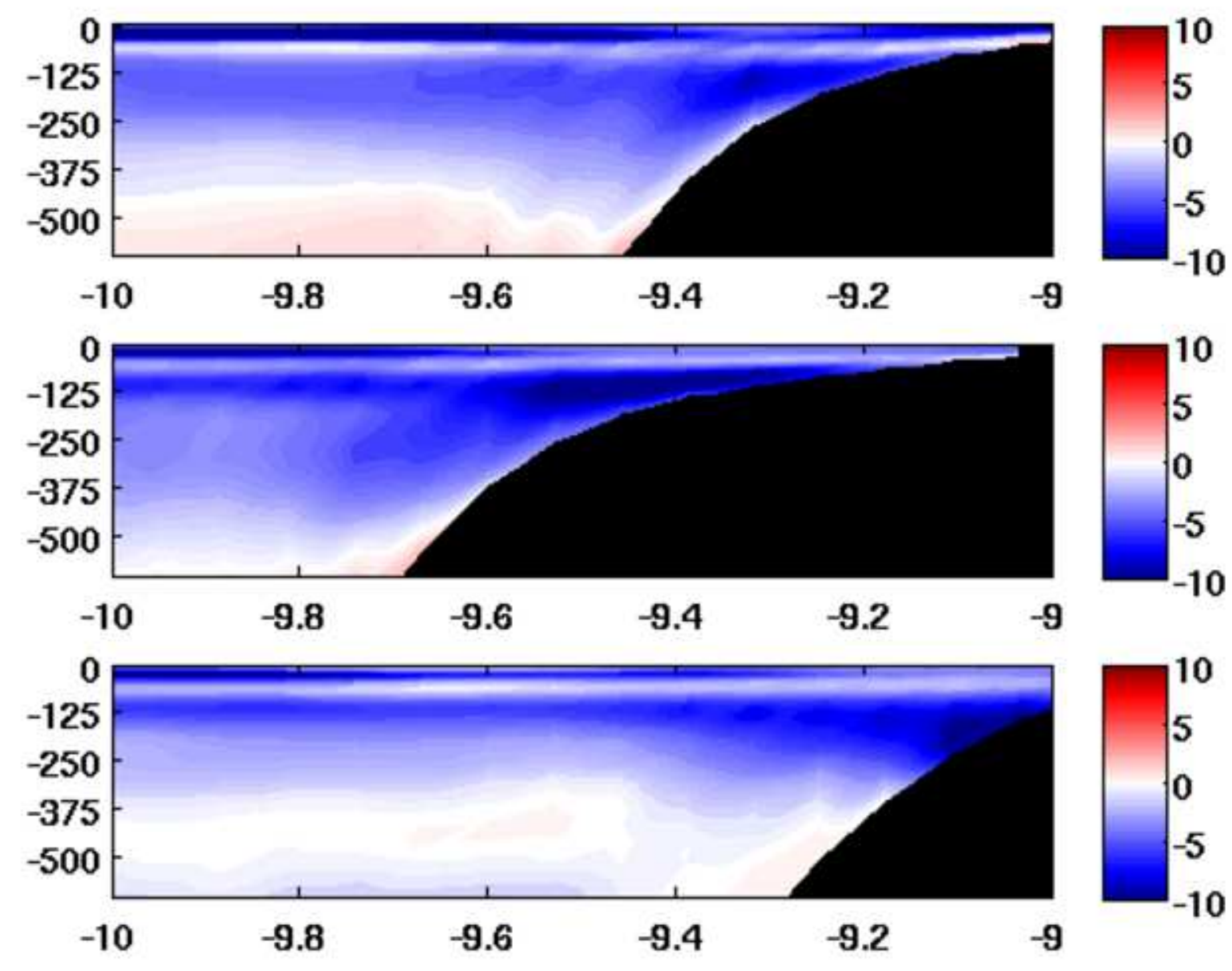

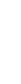


Click here to download high resolution image
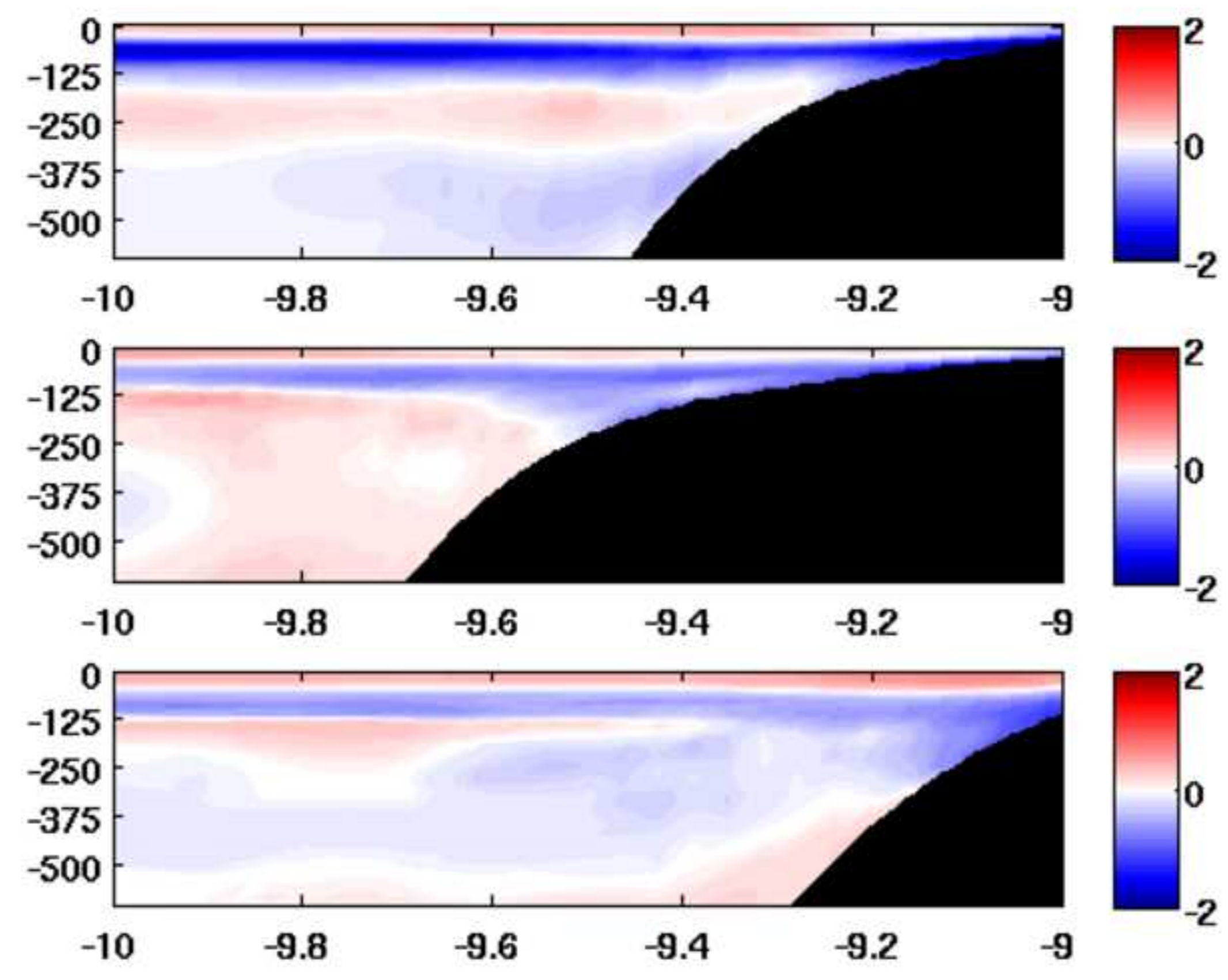

Click here to download high resolution image 

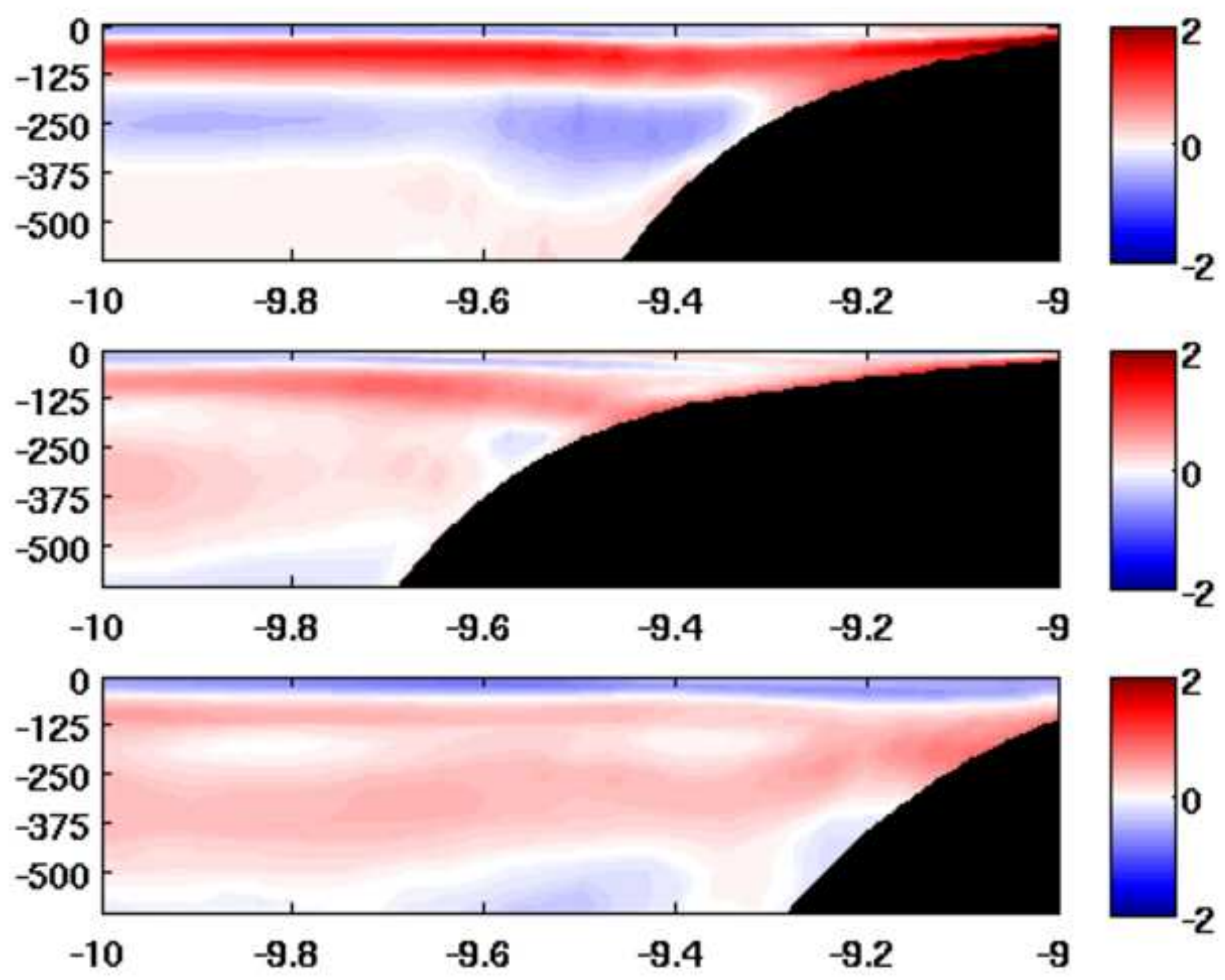
Click here to download high resolution image
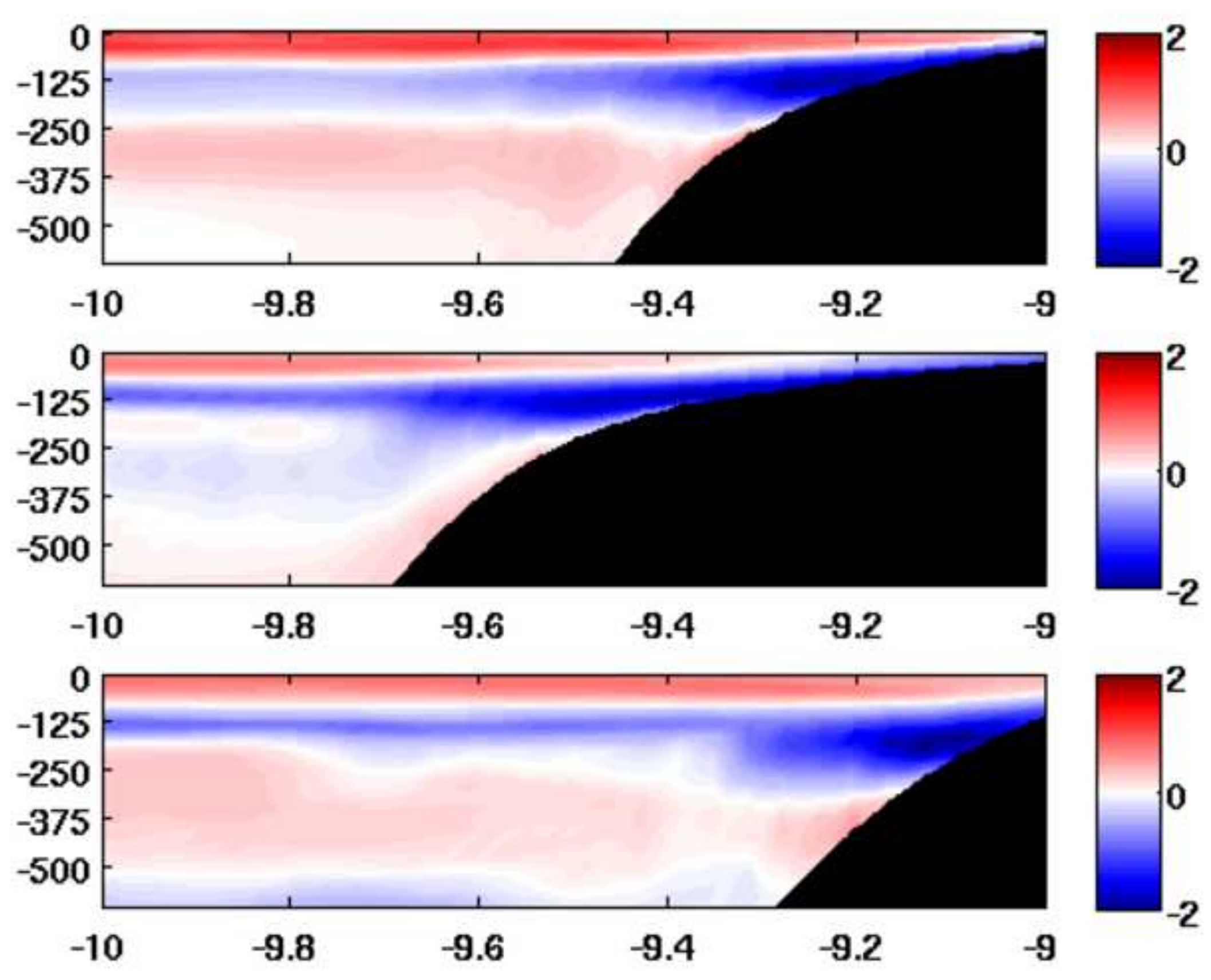

Click here to download high resolution image 
Click here to download high resolution image
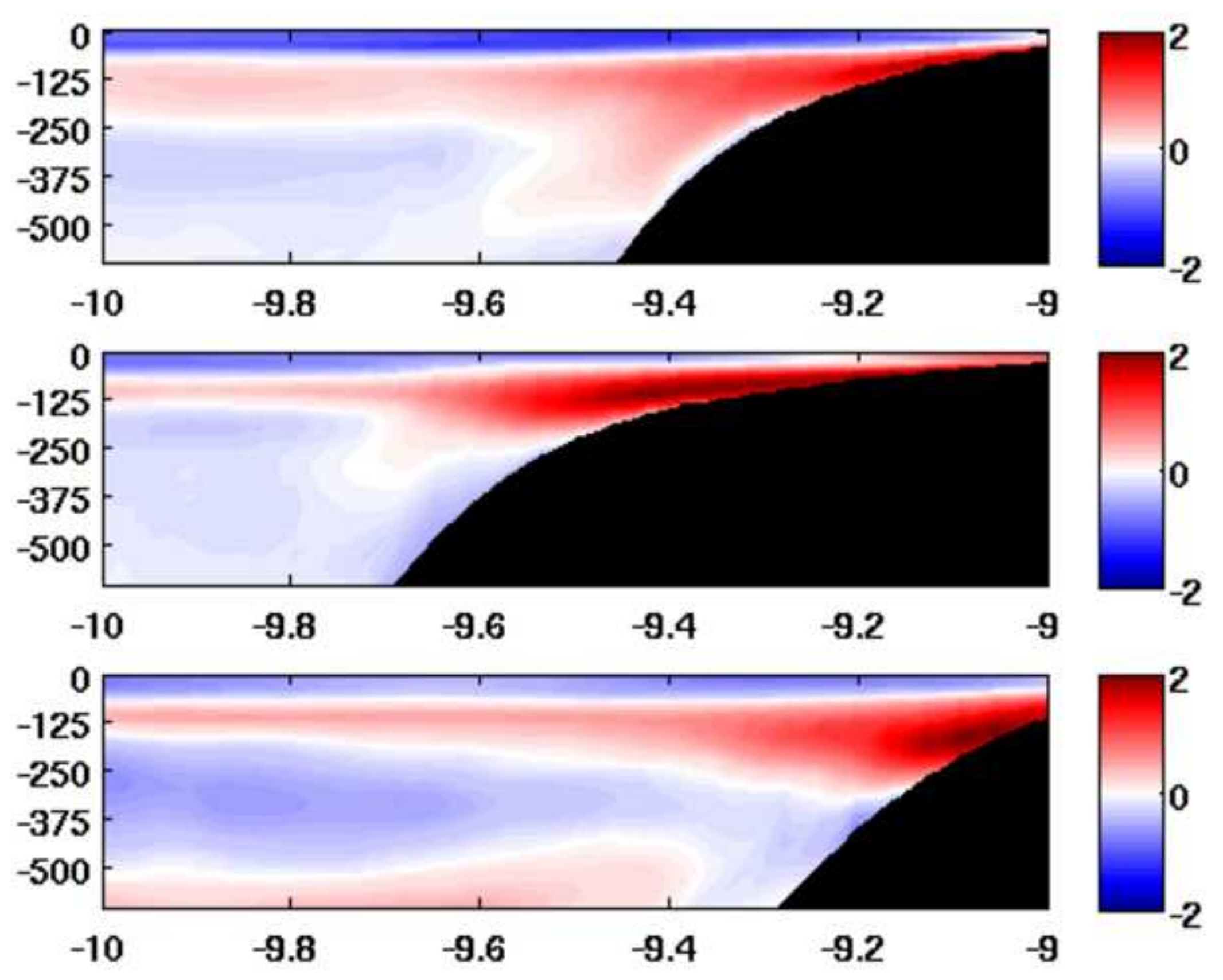

Click here to download high resolution image 
Click here to download LaTeX Source Files: Reboreda_et_al_PO.tex 


\section{LaTeX Source Files bbl}

Click here to download LaTeX Source Files: Reboreda_et_al_PO.bbl 